\title{
Textures of eclogites and blueschists from Syros island, Greece: inferences for elastic anisotropy of subducted oceanic crust
}

Ruth Keppler (1), Jan H. Behrmann (2), Michael Stipp (3)

(1) Steinmann Institute, Poppelsdorfer Schloss, 53115 Bonn, Germany rkep@uni-bonn.de

(2) Department of Geodynamics, GEOMAR Helmholtz Centre for Ocean Research Kiel, Wischhofstr. 1-3, 24148 Kiel, Germany

(3) Institute of Geology, University of Innsbruck, Innrain 52, A-6020 Innsbruck, Austria

Many blueschists and eclogites are inferred to have formed from oceanic basalts in subducted slabs. Knowledge of their elastic behaviour is essential for reconstructing the internal structure of subduction zones. The Cycladic Blueschist Unit, exposed on Syros Island (Greece), contains rocks belonging to an exhumed Tertiary subduction complex. They were possibly part of a subduction channel, a shear zone above the subducting slab in which exhumation is possible during subduction. Intense plastic deformation, forming crystallographic preferred orientations (CPO), accompanied blueschist and eclogite metamorphism. CPO of the constituent minerals in the collected samples was determined by time-of-flight neutron diffraction. Two samples are foliated fine-grained blueschists with strong CPO, rich in glaucophane, zoisite and phengite. Two coarser-grained eclogite samples rich in omphacite and clinozoisite, or glaucophane, have weaker CPO. Vp and Vs anisotropies were computed from the orientation distribution function and single-crystal elastic constants. All samples show velocity maxima parallel to the mineral lineation, and minima normal to the foliation, providing important constraints on orientations of seismic anisotropy in subduction channels. Vp anisotropies are up to three times higher (6.5-12\%) in the blueschists than in the eclogites (3-4\%), pointing to a potentially important lithological control of elastic anisotropy in subducted oceanic crust.

\section{Plain Language Summary}

Many blueschists and eclogites are inferred to have formed from oceanic basalts in subducted slabs. Knowledge of their elastic behaviour is essential for reconstructing the internal structure of subduction zones. The Cycladic Blueschist Unit, exposed on Syros Island (Greece), contains rocks belonging to an exhumed Tertiary subduction complex. They were possibly part of a subduction channel, a shear zone above the subducting slab in which exhumation is possible during subduction. Intense plastic deformation, forming crystallographic preferred orientations (CPO), accompanied blueschist and eclogite metamorphism. CPO of the constituent minerals in the collected samples was determined by time-of-flight neutron diffraction. Two samples are foliated fine-grained blueschists with strong CPO, rich in glaucophane, zoisite and phengite. Two coarser-grained eclogite samples rich in omphacite and clinozoisite, or glaucophane, have weaker CPO. Vp and Vs anisotropies were computed from the orientation distribution function and single-crystal elastic constants. All samples show velocity maxima parallel to the mineral lineation, and minima normal to the foliation, providing important constraints on orientations of seismic anisotropy in subduction channels. Vp

This article has been accepted for publication and undergone full peer review but has not been through the copyediting, typesetting, pagination and proofreading process which may lead to differences between this version and the Version of Record. Please cite this article as doi: 10.1002/2017JB014181 
anisotropies are up to three times higher (6.5-12\%) in the blueschists than in the eclogites (3-4\%), pointing to a potentially important lithological control of elastic anisotropy in subducted oceanic crust.

\section{Introduction}

Knowledge of key rock petrophysical properties is essential for reliable interpretation of seismic data. Most important is seismic velocity and its anisotropy, mainly controlled by the rock type, microstructure and the crystallographic preferred orientation (CPO) of the constituent mineral phases (e.g.: Ji. et al., 2003a; b). Despite decades of investigation, subduction zones, especially their acoustic properties at depth, are still a matter of debate (e.g. Helffrich and Stein, 1993; Essen et al. 2009; Audet et al. 2009). As velocity models from active and passive seismic surveys allow for progressively better spatial resolution, knowledge of elastic anisotropy of the constituent rocks becomes increasingly important.

Blueschists and eclogites are the subducted equivalents of basaltic oceanic crust (e.g. Ernst, 1988; Maruyama et al., 1996). Direct links between blueschist occurrence and active subduction have been successfully demonstrated (e.g. Maekawa et al., 1993; Fryer at al., 1999). Thus, the investigation of these rocks and the geometrical, tectonic and petrological reconstructions of fossil subduction complexes (e.g. Wakabayashi, 1999 Wakabayashi et al., 2015, and references therein) offer invaluable insights into fundamental processes of burial, deformation and exhumation as well as into the internal structure of subduction zones and/ or subduction channels (e.g. Behrmann and Ratschbacher 1989; Platt, 1993; Jolivet et al., 2003; Abalos et al., 2003; Malusa et al., 2011, Behr and Platt, 2013).

In seismic images the crust of some subducted oceanic slabs appears as a zone of lower seismic velocities compared to the surrounding mantle of the downgoing and overriding plates (up to $14 \%$ velocity difference to up to $150 \mathrm{~km}$ depth; e.g. Abers, 2005). This crust is preferentially composed of blueschists and/or eclogites, and is usually seismically anisotropic (e.g. Ji and Zhao, 1994; Ji et al., 1998; Kim et al., 2013). Knowledge of the orientation and magnitude of this anisotropy is, therefore, essential for the correct construction of seismic velocity models and an improved structural interpretation of subducted slabs. One approach is to investigate the anisotropy of rocks by experimental techniques at elevated pressures (e.g. Christensen, 1965; 1966; Christensen and Fountain, 1975; Kern, 1978; 1993; Fountain et al., 1994; Mauler et al., 2000; Ullemeyer et al., 2006; 2010; Kern et al., 2008), or by the recalculation of the elastic velocity using rock texture and single crystal elastic data (e.g. Bascou et al., 2001; Ji et al., 2003; Abalos et al., 2011; Keppler et al., 2015). The major issue we address in this study is how anisotropy is expected to vary between blueschistgrade and eclogite-grade subducted oceanic crust, and how it would compare with the surrounding mantle rocks. This is important, as blueschists and eclogites occupy different fields in pressuretemperature space and, therefore, reflect depth of subduction. Our study object is the Cycladic Blueschist Unit (Aegean Sea, Greece). Especially on the island of Syros high-pressure rocks of oceanic origin are well studied and coherently exposed, including blueschists and eclogites. 


\section{Geological Setting, Syros Island}

The Cycladic Blueschist unit (Fig. 1A,C), arguably one of the best-exposed fossil subduction complexes in the world (e.g., Le Pichon and Angelier, 1979; Gautier et al., 1993; Gautier and Brun, 1994; Ring and Layer, 2003; Ring and Glodny, 2010; Jolivet et al., 2013; Roche et al., 2016), has one of its most extensive occurrences on Syros Island Greece (e.g. Keiter et al., 2004). Former oceanic crust of probable Cretaceous age (Keiter et al., 2011) was subducted within the Mesohellenic Subduction System on a pressure-dominated prograde pressure-temperature path (PT-path; Fig. 1B), and rapidly exhumed thereafter. The Cycladic Blueschist Unit comprises a wide range of blueschists and eclogites with variable fabrics and compositions. The eclogites and especially the blueschists in the areas chosen for sampling (Fig. 1C) are very fresh and known for their low degree of retrogression and overprinting. This offers an ideal background for a systematic study of microstructure, CPO and petrophysical properties of subducted rocks. The metamorphic and structural record allows in principle to decipher processes of burial, high-pressure deformation and exhumation.

The Cycladic Blueschist Unit forms part of the Attic-Cycladic Crystalline Complex, which can be traced from southeast of Euboea island eastwards to Ikaria and Samos islands, and continues into the western part of the Anatolian Menderes Complex (e.g. Jacobshagen, 1986). From bottom to top there are four major tectonic units: (I) a Basement Unit, consisting of pre-Alpine granites, paragneisses and orthogneisses (los, Sikinos; van der Maar, 1980), and medium to high-grade metamorphics to migmatites on the central Cyclades (Naxos and Paros; Andriessen et al., 1987; Jacobshagen, 1986 and references therein); (II) the high-pressure/low-temperature Cycladic Blueschist Unit (mainly Syros, Sifnos, Tinos); (III) the Intermediate Unit, made up of metapelites, marbles and metabasites, and present on most of the Cycladic islands (Jansen and Schuiling, 1976; Dürr et al., 1978; Schliestedt et al., 1987); (IV) the uppermost allochthonous Pelagonian Unit with ophiolitic remnants of the Vardar Ocean, located in the hanging wall of the metamorphic core complexes of the northern (Andros, Tinos, Mykonos) and central Cyclades (Naxos and Paros; Jolivet et al., 2013; Huet et al, 2009 and references therein).

Isotopic dating suggests a complex pre-Alpine origin of the basement unit with Variscan (305-295 $\mathrm{Ma})$ and pre-Variscan ( $500 \mathrm{Ma}$ ) ages (e.g. Henjes-Kunst et al., 1988). The Alpine history of the Cyclades comprises several tectonometamorphic events that have affected the Cycladic Blueschist Unit. Subduction-related Eocene (40-50 Ma) eclogite/blueschist facies metamorphism is well documented (Fig. 1B; e.g. Schmädicke and Will, 2003; Tomaschek et al., 2003; Ring and Layer, 2003). The early exhumation path is characterized by depressurization and cooling (Parra et al., 2002), thus part of the rocks escaped retrogression, especially on Syros Island. However, an Oligo-Miocene (25$16 \mathrm{Ma}$ ) Barrovian-type greenschist facies metamorphic overprint is observed in many locations (e.g. Jansen \& Schuiling, 1976; Altherr et al., 1982; Henjes-Kunst et al. 1988; Andriessen et al., 1987; Vandenberg and Lister, 1996; Bröcker and Enders, 1999; Huet et al., 2009). The youngest tectonometamorphic history is dominated by extension, caused by the southward retreat of the subducting African slab (e.g. Le Pichon and Angelier, 1979). 
Most of Syros is made up of rocks belonging to the Cyclades Blueschist Unit (Fig. 1C), locally called Ermoupoli unit. It mostly dips moderately N to NE (e.g. Rosenbaum et al., 2002; Keiter et al., 2004; 2011) and consists of a strongly tectonized association of gneisses, schists, marbles, serpentinites and metabasites. Most of these are eclogite- to blueschist grade metamorphosed and only locally overprinted by later greenschist grade metamorphism. In the SW part of Syros, around Mavra Vounakia (Fig. 1C) this overprint is more intense, and this led us to avoid sampling there. The schists and marbles are thought of having originated from flysch sediments, whereas the metabasites and serpentinites probably have been part of an ophiolitic mélange (e.g. Dixon and Ridley, 1987; Keiter et $\mathrm{al}$, 2011). Two of these samples (SY1: $37^{\circ} 29^{\prime} 56.86^{\prime \prime} \mathrm{N} / 24^{\circ} 53^{\prime} 42.47^{\prime \prime} \mathrm{E}$, SY2: $\left.37^{\circ} 29^{\prime} 57.16^{\prime \prime} \mathrm{N} / 24^{\circ} 53^{\prime} 35.23^{\prime \prime} \mathrm{E}, \mathrm{SY} 4\right)$ come from the east-west trending blueschist-eclogite belt in the north of the island, near Kambos, near the beaches of Lia and Grammata. Another sample (SY4: $37^{\circ} 24^{\prime} 35.64^{\prime \prime} \mathrm{N} / 24^{\circ} 52^{\prime} 32.06^{\prime \prime} \mathrm{E}$ ) is from the bluschist and eclogite occurrence three kilometers north of Finikas in the western part of the island, and the fourth sample (SY5: $37^{\circ} 25^{\prime} 03.18^{\prime \prime} \mathrm{N} / 24^{\circ} 57^{\prime} 17.95^{\prime \prime} \mathrm{E}$ ) comes from the southern end of the large blueschist occurrence near the eastern coast south of Ermoupoli (Fig. 1C). These three sampling areas form the largest coherent outcrops of metabasite and sepentinite units on Syros.

\section{Methods}

CPO measurements were performed at the neutron time-of-flight (TOF) texture diffractometer SKAT at the Frank Laboratory of Neutron Physics (Joint Institute for Nuclear Research in, Dubna, Russia; Keppler et al., 2014; Ullemeyer et al., 1998). Due to the high penetration capability of neutrons in matter and the large beam cross section of the SKAT instrument, measurements of large-volume samples of up to $65 \mathrm{~cm}^{3}$ are possible, without the need for sample preparation. This allows for good grain statistics even if the investigated samples are coarse-grained. 'Rietveld Texture Analysis' (RTA) was applied for the CPO calculation using the MAUD software (Von Dreele, 1997; Matthies et al. 1997; Lutterotti et al., 1997; Wenk et al., 2010). Low $R_{w p}$ values (5.7-12.4\%) were achieved in the RTA for all samples (Von Dreele, 1997). Since RTA requires knowledge of the constituting minerals present in the sample, mineral assemblages and chemical compositions were obtained at the Steinmann-Institute Bonn using a JEOL-JXA-8900 microprobe.

The orientation distribution function (ODF) of each phase, which describes the orientation of the crystal lattice planes related to an external reference frame is finally used to model the elastic properties of the samples applying Christoffel's equation:

$<C_{i j k l}>n_{j} n_{i}-\rho V^{2} \delta_{i j}=0$

where $V$ is the velocity implying P-waves $(V p)$ and shear waves (Vs1, Vs2), $<C_{i j k}>n_{j} n_{i}$ the acoustic tensor, $C_{i j k l}$ being the single-crystal stiffness coefficient and $n$ the plane wave propagation direction, $\rho$ is the density and $\delta_{i j k}$ is the Kronecker delta. The bulk seismic properties are calculated as weighted averages of the elastic properties of the constituent mineral phases using the ODF and the corresponding single crystal elastic constants. The latter were taken from the literature (omphacite: Bhagat et al., 1992; garnet: Babuska et al., 1978; glaucophane: Bezacier et al., 2010; muscovite: Vaughan and Guggenheim, 1986; quartz: Heyliger et al., 2003; albite: Brown et al., 2006; epidote/zoisite/clinozoisite: Aleksandrov et al., 1974).. The Voigt-Reuss-Hill approximation was used 
for the calculations because it gives the closest agreement between CPO derived and laboratorymeasured seismic velocities (Seront et al., 1989).

\section{Microstructure and compostion}

The investigated blueschists contain glaucophane (50-60\%), clinozoisite ( $30 \%)$, phengite $(5-10 \%)$ and minor amounts of garnet,albite and titanite. Since the fraction of retrograde phases is small, this mineral assemblage can be assigned close to peak metamorphic conditions of the PT-path. The blueschists are fine-grained and show a pronounced shape preferred orientation (SPO) of glaucophane and clinozoisite defining the foliation and lineation. Phengite and titanite are also aligned in the foliation, and few sub-idiomorphic albite grains with a random orientation are found within the matrix (Fig. 2A, 3A and 3B). Pressure shadows of garnet mostly contain phengite, could indicate retrograde phengite growth (Fig. 3B; see Table 2A for phengite composition). Inclusions in garnet, which are glaucophane, quartz, rutile and white mica, form a foliation, oblique to the matrix foliation. The glaucophane is rich in Fe and relatively poor in Mg (see Table 1). Lowest Na contents are found in the grain centers, visible as lighter spots in Fig. 3A., arguing for prograde glaucophane growth. Garnets are zoned with increasing almandine and decreasing spessartine contents from core to rim also indicating prograde growth (Fig. 3B). Epidote is composed relatively homogenously and has a high clinozoisite component.

The eclogites are coarse-grained. They contain omphacite (35-45\%, Table $2 \mathrm{a}$ and $2 \mathrm{~b}$ ), clinozoisite (0$35 \%)$, glaucophane (0-20\%), phengite (5-20\%), garnet (5-10\%), quartz (0-15\%) and minor amounts of titanite. Sample SY2 shows randomly oriented omphacite with locally interspersed glaucophane (Fig. $2 \mathrm{C}$ ), indicating local blueschist grade overprinting. Where the fabric is dominated by glaucophane, an SPO is more pronounced (Fig. 2E). The other eclogite sample (SY4) exhibits a strong SPO (Fig. 2D) defining a pronounced foliation and lineation made up by omphacite and glaucophane. Some larger glaucophane grains have been completely replaced by smaller ones presumably indicative of dynamic recrystallization. Phengite commonly has a relatively weak preferred orientation (Fig. 2C), pointing to late stage formation after development of the glaucophane foliation (Fig. 2F). Pressure shadows around garnet contain quartz and phengite (Figs. 2D and 2F). Inclusions in garnets are quartz, white mica and glaucophane. They form a weakly defined foliation fabric oblique to the matrix foliation (Figs. 2D and 2F).

Amphibole in the eclogites is either ferro-eckermannit or ferro-glaucophane (Fig. $2 \mathrm{C}$ and Table $2 \mathrm{~A}$ ). The omphacite composition is relatively homogenous within grains (see Fig. $3 \mathrm{C}$ for location of microprobe measurements and Table $2 \mathrm{~B}$ for grain composition), but varies from sample to sample (compare grain compositions in Table 2B and Table 3; see Fig 3D for location of measurements). Omphacite is low in $\mathrm{Mg}$ and $\mathrm{Ca}$, and high in $\mathrm{Na}$ and Fe. Garnets in the eclogites exhibit a higher almandine component than in the blueschists, but also show increasing almandine and decreasing spessartine contents from core to rim indicating prograde growth (Fig. 3E). White mica in the eclogites is also phengitic (Table 2A) and epidote contains a high clinozoisite component (Table 3). 


\section{Crystallographic preferred orientation (CPO)}

The blueschists show distinct CPO of glaucophane, clinozoisite, and phengite. The [001] axis of glaucophane is either distributed within the foliation plane (Fig. 4; SY1) or forms a point maximum parallel to the mineral lineation (Fig. 4; SY5). Accordingly, [100] forms a maximum normal to the foliation or girdle structures perpendicular to the lineation, representing SL-type and LS-type CPO, respectively. The clinozoisite texture corresponds to that of glaucophane, displaying either S-types with an alignment of [010] in the foliation and a [001] point maximum normal to the foliation, or Ltypes with an alignment of [010] in lineation direction and [001] girdle structures perpendicular to the lineation. For this interpretation it needs to be taken into account that due to the crystal shape clinozoisite [010] coincides with the glaucophane [001] axis and that clinozoisite [001] coincides with the glaucophane [100] axis. Albite in the blueschists shows a random orientation (not displayed here). Phengite, if present, exhibits a weak alignment of the basal plane parallel to the foliation (Fig. 4). The CPO of all constituent mineral phases has almost orthorhombic symmetry, with the foliation and the plane normal to the lineation being mirror planes.

The eclogites show a distinct CPO of omphacite, glaucophane, clinozoisite and phengite. The [001] axis of omphacite is aligned parallel to the mineral lineation, and the [010] pole figure displays a maximum normal to the foliation with some small rotation around the lineation direction in some samples (Fig. 4; SY2 and SY4). The omphacite CPO is more pronounced in sample SY4 (Fig. 4), an observation that corresponds well to what can be seen as shape preferred orientations in the scanning electron (Fig. 3C, 3D) and optical micrographs (Fig. 2C-2F). Like for the blueschists, the clinozoisite CPO is geometrically compatible, here with that of omphacite. [010] of clinozoisite is parallel to the mineral lineation, comparable to [001] of omphacite, and [001] of clinozoisite forms a maximum normal to the foliation comparable to [010] of omphacite (Fig. 4; SY4). Glaucophane, when present in substantial amounts (Fig. 4; SY2), depicts an SL-type with weaker alignment of [001] in lineation direction than [001] of omphacite. Glaucophane [100] forms a point maximum normal to the foliation, just as omphacite [010] (Fig. 4). Phengite exhibits an alignment of its basal plane parallel to the foliation similar in topology and intensity to that of the blueschists (Fig. 4). Quartz CPO is weak and garnet displays a random orientation (not displayed here). Like for the blueschists, the $\mathrm{CPO}$ of the eclogite constituent mineral phases has the same type of symmetry.

\section{Elastic properties}

Calculated P-wave velocity ( $\mathrm{Vp}$ ) anisotropy of the blueschists is high, ranging from $6.5 \%$ to $12.1 \%$ (Table 4). Resulting elastic moduli are given in Table 5. Depending on whether there is a foliationdominated or a lineation-dominated fabric of glaucophane, maximum $V p$ is distributed in the foliation (Fig. 5; SY1) or parallel to the lineation direction (Fig. 5; SY5). The lowest Vp is found normal or nearly normal to the foliation. S-wave velocity (Vs) anisotropies are lower, ranging between 0.8 and 7.0\%, but still display clear patterns. The foliation-dominated blueschist SY1 has highest Vs1 distributed in the foliation plane, and the maxima for Vs2 are found at the periphery of the pole figure, half way between the foliation normal and the lineation (Fig. 5; SY1). In sample SY5, Vs1 forms two maxima in the foliation plane at angles of about $45^{\circ}$ to the lineation. Vs2 maxima are at the periphery of the pole figure between the foliation normal and the lineation (Fig. 5; SY5). Minima 
of S-wave velocity distributions are also distinct. In samples SY1 and SY5 lowest Vs1 velocity is oriented normal or nearly normal to the foliation. Lowest Vs2 in sample SY1 is located near the lineation, with a secondary minimum normal to the foliation. In blueschist sample SY5 Vs2 displays two minima in a girdle perpendicular to the lineation. In sample SY5, the anisotropy of Vs2 is slightly higher than that of Vs1. In contrast, in sample SY1, the anisotropy of Vs1 is well above the one of Vs2 (7.0 versus $2.4 \%)$. Vp/Vs ratios of the blueschist samples were calculated using the mean Vp and Vs velocities, and vary between 1.71 and 1.76 (Table 4).

With values of $3.3 \%$ and $3.7 \%$ the $V p$ anisotropy of the eclogites (Table 4 ) is lower by a factor of two to three than that in the blueschists. Resulting elastic moduli are given in Table 5. Both eclogite samples show highest $\mathrm{Vp}$ in the lineation direction and lowest $\mathrm{Vp}$ normal to the foliation (Fig. $5 \mathrm{SY} 2$ and SY4). Vs anisotropy lies between $0.8 \%$ and $2 \%$. Two maxima of Vs1 occur in the foliation plane at about $45^{\circ}$ to the lineation, and Vs1 minima are aligned with the foliation normal (Fig. 5, SY2 and SY4). For Vs2, maxima are at the periphery of the pole figure between the foliation normal and the lineation. Vs2 minima form a girdle distribution in sample SY2. In sample SY4 one minimum is parallel to the foliation normal, and a secondary minimum aligned with the lineation and smeared out along the foliation plane (Fig. 5, SY2 and SY4). The Vp/Vs ratio of the eclogite samples, calculated using the mean Vp and Vs velocities, is 1.69 to 1.70 (Table 4).

\section{Discussion}

The question whether mineralogical composition of subducted oceanic crust is capable of defining or modifying the seismic image of subduction zones will be the starting point of this discussion. There are two major methods for seismic investigation. In seismic tomography large rock volumes can be investigated and data on seismic velocities and anisotropies are usefull to compare subducted oceanic crust with the surrounding mantle peridotites. In reflection seismology, smaller scales, like the tectonic setting of a subduction channel are considered. Recent numerical simulations of seismic wave propagation modeled a detailed subduction channel structure with mafic blocks in a serpentinite matrix (Friedrich et al., 2014).

Generally speaking blueschists have a stability field with a lower pressure bound of about 5-6 kbar, (e.g. Bousquet et al., 2008) in a regime of low geothermal gradients. This translates to a depth in a subducted slab of about 15-18 km. Beyond a pressure of about $10 \mathrm{kbar}$, i.e. a depth of about $30 \mathrm{~km}$, conversion of blueschist to eclogite is expected to occur, principally involving breakdown of glaucophane and paragonite (e.g. Winter, 2001) on the prograde path of metamorphism, a process that can be documented on Syros (e.g. Okrusch et al., 1978; Schliestedt, 1986; Rosenbaum et al., 2002; Schmädicke and Will, 2003). The persistence of prograde glaucophane (Fig. 3A) in the eclogites (Figs. 2C, 2D) indicates that this breakdown did probably not proceed completely, until peak pressures of around $20 \mathrm{kbar}$ were attained (see Fig. 1C, and Jolivet and Brun, 2010).

Several recent numerical studies have been proposing tectonic overpressure as a major component influencing metamorphic conditions, which would indicate that many previous studiesassuming lithostatic pressures might not be correct (e.g. Burg and Gerya, 2005; Mancktelow, 2008; Angel et al., 2015; Gerya, 2015). The main factor influencing tectonic overpressure in these models is the rheology dependent heterogeneity in deforming rock units. The extent of the influence of tectonic overpressure suggested in these models, however, is not widely accepted among metamorphic 
petrologists. Klonowska et al. (2017) for example showed that in the Seve Nappe of the Scandinavian Caledonides both, strong eclogites, peridotites and the surrounding weak gneissic matrix yield evidence for ultra-high pressure conditions. According to the previously mentioned numerical models, on the other hand, this rheology contrast should have led to enormous tectonic overpressure and/or underpressure, which have not been detected. Before this and other inconsistencies between petrological data and tectonic overpressure models have not been clarified, we prefer adhere to the classical concept assuming only lithostatic pressures in the present study. As this assumption does not affect our data, the presented results could be (re-)interpreted at any later point of time.

There might be some uncertainty regarding the depth and extent of the transition zone from blueschists to eclogites, a general picture can be drawn regarding the seismic characteristics of subducted oceanic crust depending on depth. Below a depth of $15 \mathrm{~km}$, subducted oceanic crust would be highly anisotropic (6-12 \%) because of the presence of prograde blueschists with strong CPO. Comparably strong seismic anisotropies have been documented in blueschists from elsewhere before (Bezacier et al., 2010; Ha et al., 2016) and seem to be a widespread characteristic of such metamorphic belts. Blueschists making up subducted oceanic crust can also be identified by average shear wave velocities below about $4.5 \mathrm{~km} / \mathrm{s}$, and variable shear wave splitting depending on the intensity of deformation and, thus, seismic anisotropy (see Table 4).

Our observations and data regarding compositional and textural changes suggest that anisotropy in subducted oceanic crust would start vanishing below about $30 \mathrm{~km}$ due to progressive eclogitization, mainly because eclogites have much lower seismic anisotropy (1.5-3 \% texture-induced contribution). This is an observation that has also been reported by studies from other subduction complexes (e.g. Mauler et al., 2000; Keppler et al., 2015). Velocity, and Vp/Vs signature of the Syros samples is also very similar to that of other eclogites (e.g. Keppler et al., 2015). Apparently, Vp/Vs can be changed to higher values by retrograde transformation of eclogites to amphibolites (e.g. Gao et al., 2001; Keppler et al., 2015), probably owing to the growth of lower-pressure hornblende, but this is not an issue in the samples of this study. Moreover, this is a process unlikely to occur in subducted oceanic crust at great depth, but may, of course, alter the seismic signature of ophiolite complexes as they are exhumed and tectonically emplaced at higher levels in the crust.

Following a discussion of Keppler et al. (2015) the $\mathrm{Vp} / \mathrm{Vs}$ values of the blueschists and eclogites are lower than those of peridotites of the lithospheric mantle of a downgoing slab in global earth models (e.g. Kennett et al., 1995) and experimental work (e.g., Christensen, 1966, 2004; Kern, 1993; Ullemeyer et al., 2010). In a tomographic study of subducting slabs off Northern Honshu Zhang et al. (2004) concluded that the downgoing peridotite slab has $\mathrm{Vp} / \mathrm{Vs}$ ratios of $1.80-1.85$ at depths between 60 and $85 \mathrm{~km}$, and is overlain by a zone of lower $V p / V s$ ratios (1.70-1.80). This zone was interpreted to reflect subducted metagabbros of the oceanic crust that are transformed to blueschists and eclogites at depth. Our results corroborate this interpretation, and add the notion that blueschists may be visible in seismic velocity models on grounds of their pronounced anisotropy.

An interesting aspect lies in the observation that both, the eclogite and the blueschist samples show variations in fabric topology, indicating different strain histories that the samples experienced while being subducted (see e.g. discussion by Keppler et al., 2016). In the SL-type blueschist sample 
highest $\mathrm{Vp}$ is distributed within the foliation plane. The pattern is determined by the glaucophane CPO, showing a distribution of [001] within the foliation plane, which is the crystal axis closest to highest $V p$ in glaucophane single crystals. The LS-type blueschist produces highest $V p$ in the lineation direction, which is in line with an alignment of glaucophane [001] parallel to the lineation of this sample. A similar pattern for $\mathrm{Vp}$ is observed in the eclogite samples. For these, omphacite [001], the vector closest to highest $V p$ in omphacite single crystals, is aligned parallel to the lineation, yielding maximum $V p$ in the same direction. Garnet shows a random CPO, but due to its high Vp and Vs generally increases the average velocities of the samples. White mica can strongly influence the elastic anisotropy of rocks, even with low volume percentages (Mainprice and Ildefonse, 2009). However, because of its weak CPO it is a minor contributor to anisotropy in the studied samples. Based on the small sample set, however, we cannot demonstrate that strain variations are characteristic for the entire deformation path (e.g.,Abalos 1997; Abalos et al., 2011; Keppler et al., 2016), i.e. whether texture evolution followed a distinct spatial or temporal pattern (e.g., Kurz, 2005).

In the calculation of the elastic properties minor errors may be introduced by compositional differences of the minerals in our samples relative to those of the single crystal data used for modelling. Our measurements show that there are not only grain-to-grain differences in mineral chemistry within a sample but also within individual grains (Tables 1-3). Volume percentages were determined by 'Rietveld Refinement', which is not as exact as powder diffraction. However, these minor errors in mineral volume fractions produced using 'Rietveld Refinement' do not effect calculated elastic anisotropies. Further errors could have been caused by the fact that the single crystal elastic tensors are taken from measurements under ambient conditions. Some influence of pressure and temperature can be expected beyond pressures of $10 \mathrm{kbar}$. Comparison of modelled and experimentally measured data frequently shows higher values for the measured elastic anisotropies (e.g., Kern et al., 2008; Keppler et al., 2015). The velocity patterns (i.e. location of minima and maxima), however, usually are similar in measured and modelled results. Also, inaccuracy in the CPO determination is a possible error source for the calculation of the elastic anisotropy. On the other hand Keppler et al. (2014) demonstrated that even for polyphase rock samples TOF texture analysis, using RTA, leads to reliable CPO results with only minor differences in texture strength. In this study the influence of incompletely closed microcracks on the elastic anisotropy (e.g. Ullemeyer et al., 2011) was not considered. When considering material behaviour at subduction zone depth, however, it is more likely that microcracks in the subduction slab are generally closed. Elastic properties calculated from CPO could, therefore, approximate the elastic properies of crack-closed rocks at depth. 


\section{Conclusions}

Knowledge of the elastic properties of subducted oceanic crust is important for seismic investigations on active subduction zones. In this study we examined exhumed slices of blueschists and eclogites, which were subducted as part of the Hellenic subduction system and are now exposed on the island of Syros. Based on neutron texture measurements and modelling of the elastic anisotropies of the paleo-subduction zone rocks and their constituting minerals we can conclude:

1. Blueschists show larger elastic anisotropy than eclogites due to a higher single crystal elastic anisotropy of glaucophane. Accordingly, eclogites will exhibit larger elastic anisotropies if glaucophane is present.

2. The contrasting seismic properties (e.g. much higher elastic anisotropy in the blueschists compared to the eclogites) might permit the distinction between blueschists, eclogites, and possibly glaucophane-bearing eclogites in seismic imaging of subduction zones.

3. As blueschists generally occur at shallower depths than eclogites, our data imply a depth dependence of seismic anisotropy in a subducted oceanic crustal slab. In any quantification of this depth dependence, however, it needs to be considered that there is a depth range where eclogite and blueschist stabilities might overlap.

\section{ACKNOWLEDGEMENTS:}

We kindly thank Tatiana Ivankina and Benito Abalos for their constructive and very helpful comments. We are also grateful to the late Klaus Ullemeyer for his help performing the texture measurements. Michael Marks and Lisa Vielstaedter are thanked for providing insights on Syros eclogites and blueschists during discussions in the field. Funding by the German Federal Ministry of Education and Research (BMBF) is gratefully acknowledged. We also would like to thank the Frank Laboratory of Neutron Physics (FLNP) at Dubna (Russia) for support in the texture measurements. All time-of-flight spectra used for the calculations can be found on https://unibonn.sciebo.de/index.php/s/mSboAvg8hdwvNZw. 


\section{REFERENCES}

Ábalos, B., 1997. Omphacite fabric variation in the Cabo Ortegal eclogite (NW Spain):

Relationships with strain symmetry during high-pressure deformation. Journal of Structural Geology, 19, 621-637.

Ábalos, B., Fountain, D.M., Gil Ibarguchi, J.I. and Puelles, P., 2011. Eclogite as a seismic marker in subduction channels: Seismic velocities, anisotropy, and petrofabric of Cabo Ortegal eclogite tectonite (Spain). Geological Society of America Bulletin, 123, 439-456.

Abalos, B., Puelles, P., Gil Ibarguchi, J.I., 2003. Structural assemblage of high-pressure mantle and crustal rocks in a subduction channel (Cabo Ortegal, NW Spain). Tectonics 22 (2), 1006, doi:

10.1029/2002TC001405.

Abers, G.A., 2005. Seismic low-velocity layer at the top of subducting slabs: observations, predictions, and systematics. Physics of the Earth and Planetary Interiors, 149, 7-29.

Aleksandrov, K.S., Alchikov, U.V., Belikov, B.P., Zaslavski, B.I., and Krupny, A.I., 1974. Elastic wave velocities in minerals at atmospheric pressure and increasing precision of elastic constants by means of EVM. Izvestija Academy of Science USSR, Geological Series, 10, 15-24.

Altherr, R., Kreuzer, H., Wendt, I., Lenz, H., Wagner, G.A., Keller, J., Harre, W. and Hohndorf, A., 1982. A late Oligocene/early Miocene high temperature belt in the Attic-Cycladic crystalline complex (SE Pelagonian, Greece): Geologisches Jahrbuch, 23, 97-164.

Andriessen, P. A. M., Banga, G. and Hebeda, E.H., 1987. Isotopic age study of pre-Alpine rocks in the basal units on Naxos, Sikinos and los, Greek Cyclades, Geologie van de Mijnbouw, 66, 3-14.

Audet, P., Bostock, M.G., Christensen, N.I. and Peacock, S.M., 2009. Seismic evidence for overpressured subducted oceanic crust and megathrust fault sealing. Nature, 457, 76-78.

Babuska, V., Fiala, J., Kumazawa, M., Ohno, I., and Sumino, Y., 1978. Elastic properties of garnet solidsolution series. Physics of the Earth and Planetary Interiors, 16, 157-176.

Bascoua, J., Barruol, G., Vauchez, A., Mainprice, D. and Egydio-Silva, M., 2001. EBSD-measured latticepreferred orientations and seismic properties of eclogites. Tectonophysics, 342, 61-80.

Behr, W.M., Platt, J.P., 2013. Rheological evolution of a Mediterranean subduction complex. Journal of Structural Geology, 54, 136-155.

Behrmann, J.H., Ratschbacher, L., 1989. Archimedes revisited. A structural test of eclogite emplacement models in the Austrian Alps. Terra Nova, 1, 242-252.

Bezacier L., Reynard B., Bass J.D., Wang J., Mainprice D., 2010. Elasticity of glaucophane, seismic velocities and anisotropy of the subducted oceanic crust. Tectonophysics 494, 201-210.

Bhagat, S.S., Bass, J.D., and Smyth, J.R., 1992. Single-crystal elastic properties of omphacite-C2/C by Brillouin spectroscopy. Journal of Geophysical Research-Solid Earth, 97, 6843-6848.

Bousquet, R., El Mamoun, R., Saddiqi, O., Goffé, B., Möller, A., and Madi, A. , 2008. Mélanges and ophiolites during the Pan-African orogeny: the case of the Bou-Azzer ophiolite suite (Morocco) Geological Society, London, Special Publications, 297, 233-247, doi:10.1144/SP297.11 
Bröcker, M. and Enders, M., 1999. U-Pb zircon geochronology of unusual eclogite-facies rocks from Syros and Tinos (Cyclades, Greece). Geological Magazine, 136(2), 111-118.

Brown, J. M., Abramson, E. H. and Angel, R. J., 2006. Triclinic elastic constants for low albite. Physics and Chemistry of Minerals, 33, 4, 256-265.

Burg, J.-P. and Gerya, T., 2005. Viscous heating and thermal doming in orogenic metamorphism: numerical modeling and geological implications. Journal of Metamorphic Geology, 23, 75-95.

Christensen, N.I., 1965. Compressional wave velocities in metamorphic rocks at pressures to 10 kilobars. Journal of Geophysical Research 70(24), 6147-6164.

Christensen, N.I., 1966. Elasticity of ultrabasic rocks. Journal of Geophysical Research, 71, 5921-5931.

Christensen, N.I., 2004. Serpentinites, Peridotites, and Seismology. International Geology Review 46 (9), 795-816.

Christensen, N.I. and Fountain, D.M., 1975: Constitution of the lower continental crust based on experimental studies of seismic velocities in granulite. Geological Society of America Bulletin 86(2), 227-236.

Dixon, J.E., Ridley, J., 1987. Syros. In: Helgeson, H.C., (Ed.), Chemical Transport in Metasomatic Processes, Reidel Publishing Company, Dordrecht, 489-501.

Dürr, S., Seidel, E., Kreuzer, H. and Harre, W., 1978. Témoins d'un métamorphisme d'âge crétacé supérieur dans l'Egéide: Datations radiométriques de minéraux provenant de l'île de Nikouria (Cyclades, Grèce), Bulletin Géologique de la Société Francaise, 20, 209-213.

Essen, K., Braatz, M., Ceranna, L., Friederich W. and Meier, T., 2009. Numerical modelling of seismic wave propagation along the plate contact of the Hellenic Subduction Zone-the influence of a deep subduction channel. Geophysical Journal International 179, 1737-1756.

Ernst, W.G., 1988. Tectonic history of subduction zones inferred from retrograde blueschist $P-T$ paths. Geology, 27, 103-106.

Fountain, D.M., Boundy, T.M., Austrheim, H., and Rey, P., 1994. Eclogite-facies shear zones-Deep crustal reflectors? Tectonophysics, 232, 411-424.

Friederich, W., Lambrecht, L., Stöckhert, B., Wassmann, S. and Moos, C., 2014. Seismic visibility of a deep subduction channel - insights from numerical simulation of high-frequency seismic waves emitted from intermediate depth earthquakes. Solid Earth, 5, 141-159.

Fryer, P., Wheat, C.G., Mottl, M.J. 1999. Mariana blueschist mud volcanism: Implications for conditions within the subduction zone. Geology, 16, 1081-1084.

Gao, S., Kern, H., Jin, Z., Popp, T., Jin, S., Zhang, H., and Zhang, B., 2001. Poisson's ratio of eclogite: the role of retrogression. Earth Planet. Sci. Lett. 102, 523-531.

Gautier, P. and Brun, J.-P., 1994. Crustal-scale geometry and kinematics of late-orogenic extension 
in the central Aegean (C\&lades and Ewia Island). Tectonophysics 238, 399-424.

Gautier, P., Brun, J.-P. and Jolivet, L., 1993. Structure and kinematics of Upper Cenozoic extensional detachment on Naxos and Paros (Cyclades Islands, Greece). Tectonics, 12, 5, 1180 -1194.

Ha, Y., Jung, H. and Raymond L.A., 2016. Deformation fabrics of blueschist facies phengite-rich, epidote-glaucophane schists from Ring Mountain, California and implications for seismic anisotropy in subduction zone. Abstract, AGU Fall Meeting, T31E-2955

Helffrich, G.,Stein,S.,1993. Study of the structure of the slab-mantle interface using reflected and converted seismic waves. Geophys.J.Int.115,14-4072.

Henjes-Kunst, F., Altherr, R., Kreuzer, H. and Hansen, B.T., 1988. Disturbed U-Th-Pb systematics of young zircons and uranothorites: The case of the Miocene Aegean granitoids (Greece): Chemical Geology, 73, 125-145.

Heyliger, P., Ledbetter, H., Kim, S., 2003. Elastic constants of natural quartz. Journal of the Acoustical Society of America, 114, 644-650.

Huet, B., Labrousse, L., and Jolivet, L., 2009. Thrust or detachment? Exhumation processes in the Aegean: Insight from a field study on los (Cyclades, Greece): Tectonics, 28, TC3007, doi: 10.1029 /2008TC002397.

Jacobshagen, V., 1986. Geologie von Griechenland. Gebrüder Bornträger, Berlin 363 pp.

Jansen, J.B.H. and Schuiling, R.D., 1976. Metamorphism on Naxos: Petrology and geothermal gradients: American Journal of Science, 276, 1225-1253.

Ji, S., Saruwatari, K., Mainprice, D., Wirth, R., Xu, Z. and Xia B., 2003. Microstructures, petrofabrics and seismic properties of ultra high-pressure eclogites from Sulu region, China: implications

for rheology of subducted continental crust and origin of mantle reflections. Tectonophysics, 370, 4976.

$\mathrm{Ji}$, S. and Zhao, P., 1994: Layered rheological structure of subducting oceanic lithosphere. Earth Planet. Sci. Lett., 124: 75-94.

Ji, S., Wang, Z. and Saruwatari, K., 1998: Plasticity of eclogite: implications for rheology and seismic reflectivity of the subducting slab. LITHOPROBE Report no 64: 86-91.

Jolivet, L., Faccenna, C., Goffé, B., Burov, E., Agard, P., 2003. Subduction tectonics and exhumation of high-pressure metamorphic rocks in the Mediterranean orogens. American Journal of Science, 303, 353-409.

Jolivet, L., Faccenna, C., Huet, B., Labrousse, L., Le Pourhiet, L., Lacombe, O., Lecomte, E., Burov, E., Denele, Y., Brun, J.P., Philippon, M., Paul, A., Salaun, G., Karabulut, H., Piromallo, C., Monie, P., Gueydan, F., Okay, A., Oberhansli, R., Pourteau, A., Augier, R., Gadenne, L . and Driussi, O., 2013. Aegean tectonics: Strain localisation, slab tearing and trench retreat. Tectonophysics, 597, 1 -33.

Keiter, M., Ballhaus, C. and Tomaschek, F., 2011. A new geological map of the Island of Syros (Aegean Sea, Greece): implications for lithostratigraphy and structural history of the Cycladic 
blueschist unit. Geological Society of America Special Paper, 481, 43 pp.

Keiter, M., Piepjohn, K., Ballhaus, C., Lagos, M. and Bode, M, 2004. Structural development of highpressure metamorphic rocks on Syros island (Cyclades, Greece). Journal of Structural Geology, 26, 8, $1433-1445$

Kennett, B.L.N., Engdahl, E.R. and Buland, R., 1995. Constraints on seismic velocities in the Earth from travel times. Geophys. J. Int. 122, 108-124.

Keppler, R., Stipp, M., Behrmann, J.H., Ullemeyer, K. \& Heidelbach, F., 2016. Deformation inside a paleosubduction channel - Insights from microstructures and crystallographic preferred orientations of eclogites and metasediments from the Tauern Window, Austria. Journal of Structural Geology, 82, 60-79.

Keppler, R., Ullemeyer, K., Behrmann, J.H. \& Stipp, M., 2014. Potential of full pattern fit methods for the texture analysis of geological materials: implications from texture measurments at the recently upgraded neutron time-of-flight diffractometer SKAT. Journal of Applied Crystallography, 47, 15201535.

Keppler, R., Ullemeyer, K., Behrmann, J.H., Stipp, M., Kurzawski, R. \& Lokajíček, T., 2015. Crystallographic preferred orientations of exhumed subduction channel rocks from the Eclogite Zone of the Tauern Window (Eastern Alps, Austia), and implications on rock elastic anisotropies at great depths. Tectonophysics, 647, 89-104.

Kern, H., 1978. The effect of high temperature and high confining pressure on compressional wave velocities in quartz-bearing and quartz-free igneous and metamorphic rocks. Tectonophysics, 44, 185203.

Kern, H., 1993. P- and S-wave anisotropy and shear-wave splitting at pressure and temperature in possible mantle rocks and their relation to the rock fabric. Physics of the Earth and Planetary Interiors 78, 245-256.

Kern, H., Ivankina, T.I., Nikitin, A.N., Lokajíček, T., Pros, Z., 2008. The effect of oriented microcracks and crystallographic and shape preferred orientation on bulk elastic anisotropy of a foliated biotite gneiss from Outokumpu. Tectonophysics, 457, 143-149.

Kim, D., Katayama, I., MIchibayashi. K. and Tsujimori. T., 2013. Deformation fabrics of natural blueschists and implications for seismic anisotropy in subducting oceanic crust. Physics of the Earth and Planetary Interiors 222, 8-21.

Klonowska, I., Janak, M., Majka, J., Petrík, I., Froitzheim, N. Gee, D.G. and Sasinkova, V., 2017. Journal of Metamorphic Petrology. doi:10.1111/jmg.12244

Kurz, W., 2005. Constriction during exhumation: Evidence from eclogite microstructures. Geology, 33, $1,37-40$.

Le Pichon, X. and Angelier, J., 1979. The Hellenic Arc and Trench System: A Key tot he Neotectonic Evolution of the Eastern Mediterranean. Tectonophysics, 60, 1-42.

Lutterotti, L., Matthies, S., Wenk, H.-R., Schultz, A. J., and Richardson, J. W., 1997. Combined texture 
and structure analysis of deformed limestone from time-of-flight neutron diffraction spectra. Journal of Applied Physics 81, 594-600.

Maekawa, H., Shozu,I M., Ishll, T., Fryer, P., Pearce, J.A., 1993. Blueschist metamorphism in an active subduction zone. Nature, 364, 520-523.

Mainprice, D., and Ildefonse, B., 2009. Seismic Anisotropy of Subduction Zone Minerals-Contribution of Hydrous Phases. In: S. Lallemand and F. Funiciello (eds.), Subduction Zone Geodynamics, SpringerVerlag Berlin Heidelberg, 63-84.

Malusá, M.G., Faccenna, C., Garzanti, E., Polino, R., 2011. Divergence in subduction zones and exhumation of high pressure rocks (Eocene Western Alps). Earth and Planetary Science Letters, 310, 21-32.

Mancktelow, N.S., 2008. Tectonic pressure: theoretical concepts and modelled examples. Lithos, 103, 149-177.

Maruyama, S., Liou, J.G., Terabayashi, M. 1996. Blueschists and eclogites of the world and their exhumation. International Geology Review, 38, 485-594.

Matthies, S., Lutterotti, L. and Wenk, H.-R., 1997. Combined texture and structure analysis of deformed limestone from time-of-flight neutron diffraction spectra. Journal of Applied Crystallography, 28, 254-266.

Mauler, A., Burlini, L., Kunze, K., Philippot, P., and Burg, J.-P., 2000. P-wave anisotropy in eclogites and relationship to the omphacite crystallographic fabric. Phys. Chem. Earth 15, 119-126.

Okrusch, M., Seidel, E., Kreuzer, H., Harre, W., 1978. Jurassic age of metamorphism at the base of the Brecovica peridotite (Yugoslavia). Earth and Planetary Science Letters, 39, 291-297.

Parra, T., Vidal, O. and Jolivet, L., 2002. Relation between the intensity of deformation and retrogression in blueschist metapelites of Tinos Island (Greece) evidenced by chlorite-mica local equilibria. Lithos 63, 41-66.

Platt, J.P., 1993. Exhumation of high-pressure rocks: a review of concept and processes. Terra Nova 5, 119-133.

Ring, U., Glodny, J., Will, T. and Thomson, S., 2010. The Hellenic Subduction System: High-Pressure Metamorphism, Exhumation, Normal Faulting, and Large-Scale Extension. Annual Reviews of Earth and Planetary Science, 38, 45-76.

Ring, U. and Layer, P.W., 2003. High-pressure metamorphism in the Aegean, eastern Mediterranean: Underplating and exhumation from the Late Cretaceous until the Miocene to Recent above the retreating Hellenic subduction zone. Tectonics, 22, 3, doi:10.1029/2001TC001350.

Ring, U., Thomson S.N. and Bröcker, M., 2003. Fast extension but little exhumation: the Vari detachment in the Cyclades, Greece. Geological Magazine, 140, 3, 245-252.

Roche, V., Laurent, V., Cardello, G.L., Jolivet, L. and Scaillet, S., 2016. Anatomy of the Cycladic 
Blueschist Unit on Sifnos Island (Cyclades, Greece). Journal of geodynamics, 97, 62 -87.

Rosenbaum G, Avigad D, Sanchez-Gomez M (2002) Coaxial flattening at deep levels of orogenic belts: evidence from blueschists and eclogites on Syros and Sifnos (Cyclades, Greece). Journal of Structural Geology, 24, 1451-1462.

Schliestedt, M., Altherr, R. and Mattews, A., 1987. Evolution of the Cycladic crystalline complex: Petrology, isotope geochemistry and geochronology, in Chemical Transport in Metasomatic Processes, edited by H. C. Helgerson, pp. 389-428, D. Reidel, Dordrecht, Netherlands.

Schmädicke, E. and Will, T.M. 2003. Pressure-temperature evolution of blueschist facies rocks from Sifnos, Greece, and implications for the exhumation of high-pressure rocks in the central Aegean. Journal of Metamorphic Geology, 21, 799-811.

Seront, B., Mainprice, D., Christensen, N.I., 1989. The complete seismic properties of an anorthosite: comparison between LPO and laboratory measurements. EOS 70, 460-461.

Tomaschek, F., Kennedy, A., Villa, I.M., Lagos, M., Ballhaus, C., 2003. Zircons from Syros, Cyclades, Greece-recrystallization and mobilisation during high-pressure metamorphism. Journal of Petrology, 44, 1977-2002.

Trotet, F., Jolivet, L. and Vidal, O., 2001a. Tectono-metamorphic evolution of Syros and Sifnos islands (Cyclades, Greece). Tectonophysics, 338, 179-206.

Trotet, F., Vidal, O., Jolivet, L., 2001b. Exhumation of Syros and Sifnos metamorphic rocks (Cyclades, Greece). New constraints on the P-T paths. European Journal of Mineralogy, 13, 901-920.

Ullemeyer, K., Leiss, B., Stipp, M., 2010. Textures and Microstructures in Peridotites from the Finero Complex (Ivrea Zone, Alps) and their Influence on the Elastic Rock Properties. Solid State Phenomena $160,183-188$.

Ullemeyer, K., Nikolayev, D.I., Christensen, N.I., Behrmann, J.H., 2011. Evaluation of intrinsic velocitypressure trends from low-pressure P-wave velocity measurements in rocks containing microcracks. Geophys. J. Int. 185, 1312-1320.

Ullemeyer, K., Siegesmund, S., Rasolofosaon, P.N.J., Behrmann, J.H., 2006. Experimental and texturederived $\mathrm{P}$-wave anisotropy of principal rocks from the TRANSALP traverse: an aid for the interpretation of seismic field data. Tectonophysics, 414, 97-116.

Ullemeyer, K., Spalthoff, P., Heinitz, J., Isakov, N. N., Nikitin, A. N., Weber, K., 1998. The SKAT texture diffractometer at the pulsed reactor IBR-2 at Dubna: Experimental layout and first measurements. Nuclear Instruments and Methods of Physical Research, 412, 80-88.

Vandenberg, L. C., and Lister, G.S., 1996. Structural analysis of basement tectonics from the Aegean metamorphic core complex of los, Cyclades, Greece. Journal of Structural Geology, 18, 1437-1454.

van der Maar, P., 1980. The geology and petrology of los, Cyclades, Greece, Ann. Geol. Pays Helleniques, 30, 206-224.

Vaughan, M.T, Guggenheim, S., 1986. Elasticity of muscovite and its relationship to crystal structure. Journal of Geophysical Research 91, 4657-4664. 
Von Dreele, R.B., 1997. Quantitative texture analysis by Rietveld refinement. Journal of Applied Crystallography, 30, 577-587.

Wakabayashi, J. 1999. Subduction and the rock record: Concepts developed in the Franciscan Complex, California, in Moores EM, Sloan D, Stout DL (eds), Classic Cordilleran Concepts: A View from California: Boulder, Colorado, Geological Society of America Special Paper, 338, 123-133.

Wakabayashi, J., Tsujimori, T., Ogawa, Y., Shervais, J., 2015. Convergent plate margin processes and their rock record. International Geology Review, 57 (5-8), v-ix, DOI: 10.1080/00206814.2015.1026415 Wenk, H.-R., Lutterotti, L. and Vogel, S. C., 2010. Rietveld texture analysis from TOF neutron diffraction data. Powder Diffraction 25, 3, 283-296.

Wenk, H.-R., Lutterotti, L. and Vogel, S. C., 2010. Rietveld texture analysis from TOF neutron diffraction data. Powder Diffraction 25, 3, 283-296.

Winter, J.D., 2001. An introduction to igneous and metamorphic petrology. Prentice Hall, New Jersey, $687 \mathrm{pp}$.

Zhang, H., Thurber, C.H., Shelly, D., Ide, S., Beroza, G.C. and Hasegawa, A., 2004. High resolution subducting-slab structure beneath northern Honshu, Japan, revealed by double-difference tomography. Geology 42, 361-364. http://dx.doi.org/10.1130/G20261.2.

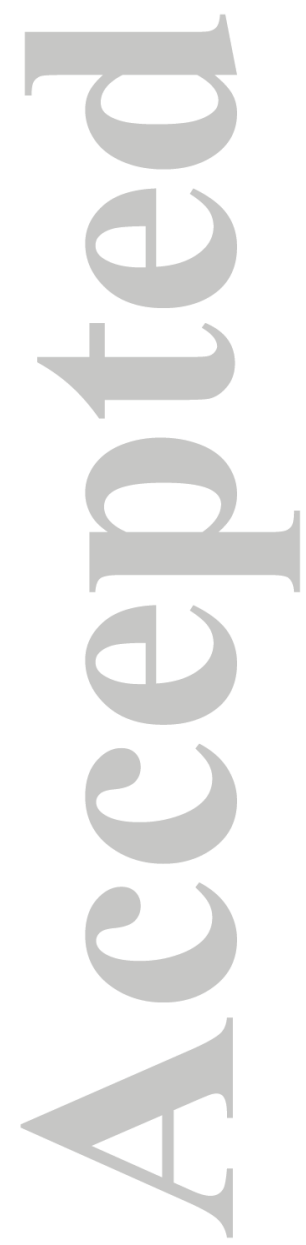


Table 1: Microprobe measurements of glaucophane in blueschist sample SY1. See Fig. 3A for location of measurements.

\begin{tabular}{|c|c|c|c|c|c|c|c|c|c|c|c|}
\hline 2 & 58.158 & 57.466 & 56.294 & 54.942 & 52.82 & 57.289 & 57.787 & 57.82 & 58.212 & 57.972 & 57.791 \\
\hline $\begin{array}{l}\mathrm{TiO} \\
2\end{array}$ & 0.019 & 0.034 & 0.111 & 0.069 & 0.157 & 0.045 & 0.016 & 0.05 & 0.069 & 0.079 & 0.074 \\
\hline $\begin{array}{l}\mathrm{Al} 2 \\
\mathrm{O} 3\end{array}$ & 11.319 & 11.432 & 11.619 & 11.015 & 9.591 & 11.412 & 11.334 & 11.366 & 11.425 & 11.492 & 11.307 \\
\hline $\begin{array}{l}\mathrm{Cr} 2 \\
\mathrm{O} 3\end{array}$ & 0 & 0.031 & 0.008 & 0.01 & 0 & 0.013 & 0.013 & 0.023 & 0.045 & 0.028 & 0 \\
\hline $\begin{array}{l}\mathrm{Fe} \\
\mathrm{O}\end{array}$ & 9.537 & 9.868 & 9.853 & 10.784 & 11.213 & 10.011 & 9.399 & 9.296 & 9.756 & 10.233 & 9.466 \\
\hline $\begin{array}{l}\mathrm{Mn} \\
\mathrm{O}\end{array}$ & 0 & 0.043 & 0.086 & 0.038 & 0.081 & 0.059 & 0.005 & 0.032 & 0.021 & 0.086 & 0.07 \\
\hline $\begin{array}{l}\mathrm{Mg} \\
\mathrm{O}\end{array}$ & 10.628 & 10.505 & 10.446 & 11.178 & 12.625 & 10.414 & 10.699 & 10.299 & 10.493 & 10.417 & 10.628 \\
\hline $\begin{array}{l}\mathrm{Ca} \\
\mathrm{O}\end{array}$ & 0.815 & 1.154 & 2.253 & 3.83 & 6.882 & 1.261 & 0.888 & 0.597 & 0.76 & 0.99 & 0.972 \\
\hline $\begin{array}{l}\mathrm{Na} \\
2 \mathrm{O}\end{array}$ & 7.096 & 6.987 & 6.407 & 5.456 & 3.93 & 6.949 & 7.293 & 7.414 & 7.086 & 6.839 & 7.26 \\
\hline $\begin{array}{l}\mathrm{K} 2 \\
\mathrm{O}\end{array}$ & 0.004 & 0.017 & 0.075 & 0.1 & 0.213 & 0.017 & 0.015 & 0.01 & 0.013 & 0.012 & 0.009 \\
\hline & 97.576 & 97.537 & 97.152 & 97.422 & 97.512 & 97.47 & 97.449 & 96.907 & 97.88 & 98.148 & 97.577 \\
\hline
\end{tabular}

\begin{tabular}{|c|c|c|c|c|c|c|c|c|c|c|c|}
\hline $\mathrm{Si}$ & $\begin{array}{r}7.93084 \\
03787\end{array}$ & $\begin{array}{r}7.86893 \\
16226\end{array}$ & \begin{tabular}{|r|}
7.78851 \\
44776 \\
\end{tabular} & $\begin{array}{r}7.62293 \\
46084\end{array}$ & $\begin{array}{r}7.42275 \\
44777\end{array}$ & $\begin{array}{r}7.86200 \\
79286\end{array}$ & $\begin{array}{r}7.90933 \\
75001\end{array}$ & $\begin{array}{r}7.96040 \\
27497\end{array}$ & \begin{tabular}{r|}
7.91729 \\
59388
\end{tabular} & \begin{tabular}{|r}
7.87035 \\
56105
\end{tabular} & $\begin{array}{r}7.90898 \\
9659 \\
\end{array}$ \\
\hline Al & $\begin{array}{r}0.06915 \\
96213 \\
\end{array}$ & $\begin{array}{r}0.13106 \\
83774\end{array}$ & $\begin{array}{r}0.21148 \\
55224\end{array}$ & $\begin{array}{r}0.37706 \\
53916\end{array}$ & $\begin{array}{r}0.57724 \\
55223\end{array}$ & $\begin{array}{r}0.13799 \\
20714\end{array}$ & $\begin{array}{r}0.09066 \\
24999\end{array}$ & $\begin{array}{r}0.03959 \\
72503\end{array}$ & $\begin{array}{r}0.08270 \\
40612\end{array}$ & $\begin{array}{r}0.12964 \\
43895\end{array}$ & $\begin{array}{r}0.09101 \\
0341\end{array}$ \\
\hline Al & $\begin{array}{r}1.74990 \\
40421\end{array}$ & $\begin{array}{r}1.71376 \\
48479\end{array}$ & $\begin{array}{r}1.68300 \\
03339 \\
\end{array}$ & $\begin{array}{r}1.42401 \\
17901\end{array}$ & $\begin{array}{r}1.01115 \\
74191\end{array}$ & $\begin{array}{r}1.70767 \\
80927\end{array}$ & $\begin{array}{r}1.73753 \\
56292\end{array}$ & $\begin{array}{r}1.80454 \\
61907\end{array}$ & $\begin{array}{r}1.74855 \\
86809\end{array}$ & \begin{tabular}{|r}
1.70901 \\
71105 \\
\end{tabular} & $\begin{array}{l}.73262 \\
61895 \\
\end{array}$ \\
\hline \begin{tabular}{|l}
$\mathrm{Fe}(\mathrm{i}$ \\
ii)
\end{tabular} & $\begin{array}{r}0.20053 \\
4365 \\
\end{array}$ & $\begin{array}{r}0.21056 \\
48794 \\
\end{array}$ & $\begin{array}{r}0.10485 \\
75851 \\
\end{array}$ & $\begin{array}{r}0.31368 \\
95254 \\
\end{array}$ & $\begin{array}{r}0.35181 \\
06668 \\
\end{array}$ & $\begin{array}{r}0.19703 \\
43899 \\
\end{array}$ & $\begin{array}{r}0.15019 \\
27657 \\
\end{array}$ & $\begin{array}{r}0.06545 \\
40387 \\
\end{array}$ & $\begin{array}{r}0.22303 \\
98076 \\
\end{array}$ & \begin{tabular}{|r}
0.31141 \\
12786 \\
\end{tabular} & $\begin{array}{r}0.13033 \\
71526 \\
\end{array}$ \\
\hline $\mathrm{Ti}$ & $\begin{array}{r}0.00194 \\
87459 \\
\end{array}$ & $\begin{array}{r}0.00350 \\
1673 \\
\end{array}$ & $\begin{array}{r}0.01155 \\
06751 \\
\end{array}$ & $\begin{array}{r}0.00720 \\
04342 \\
\end{array}$ & $\begin{array}{r}0.01659 \\
42726\end{array}$ & $\begin{array}{r}0.00464 \\
47957 \\
\end{array}$ & $\begin{array}{r}0.00164 \\
7107 \\
\end{array}$ & $\begin{array}{r}0.00517 \\
74847 \\
\end{array}$ & $\begin{array}{r}0.00705 \\
83846 \\
\end{array}$ & \begin{tabular}{|r}
0.00806 \\
66838 \\
\end{tabular} & $\begin{array}{r}0.00761 \\
70075 \\
\end{array}$ \\
\hline $\mathrm{Cr}$ & 0 & $\begin{array}{r}0.00335 \\
59185\end{array}$ & $\begin{array}{r}0.00087 \\
5039 \\
\end{array}$ & $\begin{array}{r}0.00109 \\
68889 \\
\end{array}$ & 0 & $\begin{array}{r}0.00141 \\
04266\end{array}$ & $\begin{array}{r}0.00140 \\
66894 \\
\end{array}$ & $\begin{array}{r}0.00250 \\
33968\end{array}$ & $\begin{array}{r}0.00483 \\
86229 \\
\end{array}$ & $\begin{array}{r}0.00300 \\
52389\end{array}$ & 0 \\
\hline $\begin{array}{l}\mathrm{Fe}(\mathrm{i} \\
\text { i) }\end{array}$ & $\begin{array}{r}0.88695 \\
41526 \\
\end{array}$ & $\begin{array}{r}0.91932 \\
75411 \\
\end{array}$ & $\begin{array}{r}1.03503 \\
55996 \\
\end{array}$ & $\begin{array}{r}0.93743 \\
56422 \\
\end{array}$ & $\begin{array}{r}0.96581 \\
38663 \\
\end{array}$ & $\begin{array}{r}0.95176 \\
14358 \\
\end{array}$ & $\begin{array}{r}0.92551 \\
61301 \\
\end{array}$ & $\begin{array}{r}1.00472 \\
44578 \\
\end{array}$ & $\begin{array}{r}0.88649 \\
08356 \\
\end{array}$ & \begin{tabular}{|r}
0.85025 \\
71807 \\
\end{tabular} & $\begin{array}{r}0.95291 \\
72179 \\
\end{array}$ \\
\hline $\mathrm{Mn}$ & 0 & $\begin{array}{r}0.00498 \\
66857 \\
\end{array}$ & $\begin{array}{r}0.01007 \\
69642 \\
\end{array}$ & $\begin{array}{r}0.00446 \\
51913 \\
\end{array}$ & $\begin{array}{r}0.00964 \\
0298 \\
\end{array}$ & $\begin{array}{r}0.00685 \\
72974 \\
\end{array}$ & $\begin{array}{r}0.00057 \\
95871 \\
\end{array}$ & $\begin{array}{r}0.00373 \\
11755 \\
\end{array}$ & $\begin{array}{r}0.00241 \\
89249 \\
\end{array}$ & $\begin{array}{r}0.00988 \\
81094 \\
\end{array}$ & \begin{tabular}{r|}
0.00811 \\
33008 \\
\end{tabular} \\
\hline $\mathrm{Mg}$ & $\begin{array}{r}2.16065 \\
86944 \\
\end{array}$ & $\begin{array}{r}2.14449 \\
84545\end{array}$ & $\begin{array}{r}2.15460 \\
38032 \\
\end{array}$ & $\begin{array}{r}2.31210 \\
05279 \\
\end{array}$ & $\begin{array}{r}2.64498 \\
34772 \\
\end{array}$ & $\begin{array}{r}2.13061 \\
3562 \\
\end{array}$ & $\begin{array}{r}2.18312 \\
20915 \\
\end{array}$ & $\begin{array}{r}2.11386 \\
32559 \\
\end{array}$ & $\begin{array}{r}2.12759 \\
47436 \\
\end{array}$ & \begin{tabular}{|r|}
2.10835 \\
43982 \\
\end{tabular} & $\begin{array}{r}2.16838 \\
91316 \\
\end{array}$ \\
\hline $\mathrm{Ca}$ & $\begin{array}{r}0.11906 \\
6414 \\
\end{array}$ & $\begin{array}{r}0.16929 \\
04778 \\
\end{array}$ & \begin{tabular}{|r|}
0.33394 \\
55291 \\
\end{tabular} & $\begin{array}{r}0.56929 \\
63806 \\
\end{array}$ & $\begin{array}{r}1.03610 \\
38467 \\
\end{array}$ & $\begin{array}{r}0.18539 \\
55226 \\
\end{array}$ & $\begin{array}{r}0.13021 \\
01514 \\
\end{array}$ & $\begin{array}{r}0.08805 \\
48342 \\
\end{array}$ & $\begin{array}{r}0.11073 \\
88143 \\
\end{array}$ & $\begin{array}{r}0.14399 \\
02832 \\
\end{array}$ & \begin{tabular}{r|}
0.14251 \\
11951 \\
\end{tabular} \\
\hline $\mathrm{Na}$ & $\begin{array}{r}1.87599 \\
51036\end{array}$ & $\begin{array}{r}1.85482 \\
90708\end{array}$ & $\begin{array}{r}1.71852 \\
39717 \\
\end{array}$ & $\begin{array}{r}1.46757 \\
54533\end{array}$ & $\begin{array}{r}1.07069 \\
94927\end{array}$ & $\begin{array}{r}1.84881 \\
2613 \\
\end{array}$ & $\begin{array}{r}1.93519 \\
40512\end{array}$ & $\begin{array}{r}1.97887 \\
28186\end{array}$ & $\begin{array}{r}1.86841 \\
71876\end{array}$ & \begin{tabular}{|r}
1.80001 \\
87282 \\
\end{tabular} & $\begin{array}{r}1.92621 \\
94628 \\
\end{array}$ \\
\hline
\end{tabular}




\begin{tabular}{|l|r||r|r|r|r|r|r|r|r|r|r|}
\hline K & 0.00069 & 0.00296 & 0.01323 & 0.01769 & 0.03818 & 0.00297 & 0.00261 & 0.00175 & 0.00225 & 0.00207 & 0.00157 \\
\hline TO & 14.9957 & 93592 & 61842 & 81042 & 17051 & 59126 & 88477 & 61676 & 53644 & 80995 & 11307 \\
\hline TAL & 573085 & 889077 & 15.0657 & 15.0545 & 15.1449 & 15.0371 & 15.0680 & 15.0686 & 14.9814 & 14.9460 & 15.0703 \\
\hline
\end{tabular}
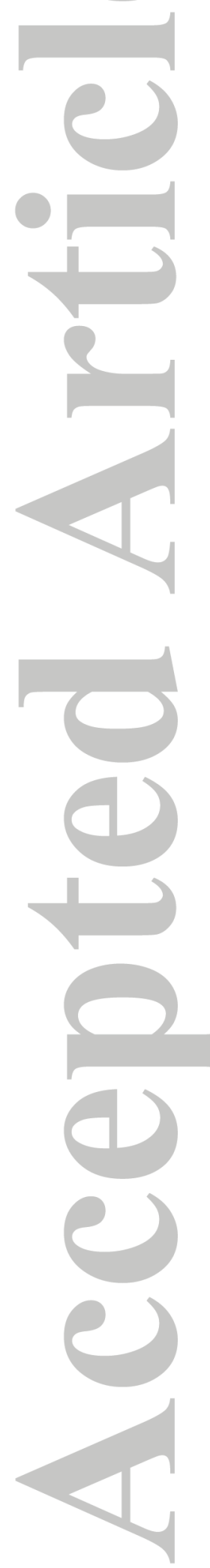

(C) 2017 American Geophysical Union. All rights reserved. 
Table 2: Microprobe data of (A) amphibole and white mica; (B) omphacite in eclogite sample SY2. See Fig. $3 C$ for location of measurements.

Sy2 amp line

\begin{tabular}{|c|c|c|c|c|c|c|c|c|c|c|c|c|c|c|c|c|c|}
\hline & 1 & 2 & 3 & 4 & 5 & 6 & 7 & 8 & 9 & 10 & 11 & 12 & 13 & 14 & 15 & 16 & 17 \\
\hline Si & & & & & & & & & & & & & & & & & \\
\hline 0 & 47.73 & 50.90 & 49.88 & 47.55 & 50.78 & 50.59 & $\mid 50.74$ & 50.66 & 51.08 & 50.8 & 50.38 & 50.75 & 50.67 & 50.72 & $\mid 51.42$ & 49.92 & \\
\hline 2 & 4 & & & & & & & & & 91 & & & & & & & 50.62 \\
\hline $\mathrm{Ti}$ & & & & & & & & & & & & & & & & & \\
\hline O & & & & & & & & & & 0.22 & & & & & & & \\
\hline 2 & 0.202 & 0.172 & 0.311 & 0.221 & 0.261 & 0.227 & | 0.224 & 0.254 & 0.182 & & 0.245 & 0.166 & 0.232 & |0.264|| & $\mid$ & 0.243 & 0.243 \\
\hline$|A|$ & & & & & & & & & & & & & & & & & \\
\hline 0 & 27.28 & 28.51 & 28.54 & 27.56 & 28.41 & 28.77 & 29.22 & 28.54 & & 28.7 & 28.64 & 28.52 & 28.77 & $27.92 \mid$ & $\mid$ & |28.11 & 28.34 \\
\hline 3 & 9 & & & 1 & 4 & & & & 28.66 & 63 & & 2 & 5 & 6 & & 7 & \\
\hline $\mathrm{Cr}$ & & & & & & & & & & & & & & & & & \\
\hline 0 & & & & & & & & & & 0.01 & & & & & & & \\
\hline 3 & 0 & & 0 & 0 & 0 & 0.028 & 0.022 & 0 & 0.008 & 5 & 0.013 & 0.01 & 0 & 0.036 & 0.005 & 0 & 0 \\
\hline $\mathrm{Fe}$ & & & & & & & & & & 4.43 & & & & & & & \\
\hline 0 & 8.659 & 5.064 & 5.13 & 5.433 & 4.969 & 5.101 & 4.753 & 4.403 & 4.555 & & 5.362 & 4.869 & 4.639 & 4.963 & $\mid 4.878$ & 5.438 & 5.006 \\
\hline$M$ & & 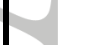 & & & & & & & & & & & & & & & \\
\hline 0 & 004 & & & & 0.01 & 0 & 0.025 & 0 & 0.041 & $\begin{array}{r}0.01 \\
5\end{array}$ & 0,03 & 0.01 & 0 & 0 & 10046 & & $\ln 086$ \\
\hline$M$ & & & & & & & & & & & & & & & & & \\
\hline & & & & & & & & & & 1.97 & & & & & & & \\
\hline 0 & 1.937 & 1.967 & 1.823 & 1.76 & 2.122 & 1.571 & 1.956 & 2.061 & 2.051 & 8 & 1.903 & 1.965 & 2.004 & 2.056 & || & 1.809 & 2.02 \\
\hline$C$ & & & & & & & & & & & & & & & & & \\
\hline $\mathrm{O}^{\mathrm{a}}$ & 0.089 & 0 & 0.006 & 0.131 & 0 & & 0.001 & 0 & 0.006 & $\begin{array}{r}0.00 \\
7\end{array}$ & 0 & 0.03 & 0.008 & 0 & 0 & 0.01 & 0 \\
\hline$N$ & & & & & & & & & & & & & & & & & \\
\hline & & & & & & & & & & 0.45 & & & & & & & \\
\hline 0 & 0.339 & 0.371 & 0.46 & 0.397 & 0.72 & 0.225 & 0.417 & 0.418 & 0.386 & 5 & 0.379 & 0.371 & 0.522 & 0.451 & 0.417 & 0.38 & 0.509 \\
\hline K & & & & & & & & & & & & & & & & & \\
\hline 2 & 10.38 & 11.06 & 10.79 & 10.28 & 10.83 & 11.17 & 11.09 & 11.00 & 10.89 & 10.9 & 11.10 & 10.93 & 10.95 & |11.02 & & |10.67 & 10.91 \\
\hline 0 & 7 & 2 & 3 & 8 & & & 8 & 2 & & 23 & 7 & 6 & 6 & 9 & $\mid 10.92$ & 4 & 5 \\
\hline & 96.67 & 98.05 & 96.94 & & 98.11 & 97.69 & 98.46 & 97.35 & 97.86 & \begin{tabular}{|l|l|}
97.7 \\
\end{tabular} & 98.06 & 97.63 & 97.80 & & 98.54 & 96.59 & 97.74 \\
\hline $\mathrm{m}$ & 6 & 17 & & 93.35 & & & & & 9 & 12 & 9 & 2 & & 97.45 & | 6 & 4 & \\
\hline
\end{tabular}

\begin{tabular}{|c|c|c|c|c|c|c|c|c|c|c|c|c|c|c|c|c|c|}
\hline & 6.809 & 7.008 & 6.952 & 6.904 & 6.989 & 6.994 & |6.950 & 7.004 & 7.020 & 7.00 & 6.956 & 7.008 & 6.981 & 7.030 & 7.029 & 6.986 & 6.995 \\
\hline \multirow[b]{2}{*}{ Si } & 7159 & 8737 & 0964 & 5698 & 0836 & 4179 & ||9645 & 9302 & 7238 & 5802 & 6442 & 2576 & 8033 & 5954 & 0846 & 6414 & 0255 \\
\hline & 221 & 536 & 847 & 838 & 639 & 148 & 33 & 583 & 17 & 263 & 172 & 167 & 63 & 952 & 03 & 114 & 704 \\
\hline & 1.190 & .991 & 1.047 & 1.095 & 1.010 & 1.005 & 1.049 & 0.995 & 0.979 & 0.99 & 1.043 & 0.991 & 1.018 & 0.969 & 0.970 & 1.013 & 1.004 \\
\hline & 2840 & 1262 & 9035 & 4301 & 9163 & 5820 & 0354 & 0697 & 2761 & 4197 & 3557 & 7423 & 1966 & 4045 & 9153 & 3585 & 9744 \\
\hline Al & 779 & 464 & 153 & 162 & 361 & 852 & 67 & 417 & 83 & 737 & 828 & 833 & 37 & 048 & \begin{tabular}{||l}
97 \\
\end{tabular} & 886 & 296 \\
\hline & & & & & & & & & & & & & & & & & \\
\hline & 3.397 & 3.634 & 3.639 & 3.620 & 3.597 & 3.681 & 3.668 & 3.656 & 3.662 & 3.67 & 3.617 & 3.649 & 3.654 & 3.592 & 3.642 & 3.623 & 3.611 \\
\hline & 6680 & 9357 & 8255 & 0832 & 3619 & 7409 & $\mid$\begin{tabular}{||l}
$\mid 5939$ \\
\end{tabular} & 5008 & 9765 & 2193 & 1160 & 7581 & 1647 & 1081 & 7673 & 9591 & 4354 \\
\hline Al & 789 & 243 & 702 & 395 & 759 & 255 & 594 & 786 & 135 & 6806 & 458 & 821 & 005 & 327 & 883 & 324 & 538 \\
\hline $\mathrm{Fe}$ & & & & & & & & & & & & & & & & & \\
\hline i) & 0 & 0 & 0 & 0 & 0 & 0 & 0 & 0 & 0 & 0 & 0 & 0 & 0 & 0 & 0 & & \\
\hline
\end{tabular}




\begin{tabular}{|c|c|c|c|c|c|c|c|c|c|c|c|c|c|c|c|c|c|}
\hline $\mathrm{Ti}$ & $\mid \begin{array}{r}0.021 \\
6742 \\
662\end{array}$ & $\begin{array}{r}0.017 \\
8104 \\
128\end{array}$ & $\begin{array}{r}0.032 \\
5998 \\
411\end{array}$ & $\mid \begin{array}{r}0.024 \\
1317 \\
077\end{array}$ & $\begin{array}{r}0.027 \\
0152 \\
261\end{array}$ & $\begin{array}{r}0.023 \\
6008 \\
35\end{array}$ & $\begin{array}{r}0.023 \\
0785 \\
659\end{array}$ & $\begin{array}{r}0.026 \\
4121 \\
777\end{array}$ & $\begin{array}{r}0.018 \\
8141 \\
999\end{array}$ & $\begin{array}{c}0.02 \\
3503 \\
6123\end{array}$ & $\begin{array}{r}0.025 \\
4412 \\
967\end{array}$ & $\begin{array}{r}0.017 \\
2404 \\
38\end{array}$ & $\begin{array}{r}0.024 \\
0420 \\
142\end{array}$ & $\begin{array}{r}0.027 \\
5211 \\
039\end{array}$ & $\mid \begin{array}{r}0.021 \\
9990 \\
93\end{array}$ & $\begin{array}{r}0.025 \\
5779 \\
609\end{array}$ & $\begin{array}{r}0.025 \\
2560 \\
429\end{array}$ \\
\hline $\mathrm{Cr}$ & 0 & 0 & 0 & 0 & 0 & $\begin{array}{r}0.003 \\
0599 \\
377\end{array}$ & $\mid \begin{array}{r}0.002 \\
3825 \\
198\end{array}$ & 0 & $\begin{array}{r}0.000 \\
8692 \\
754\end{array}$ & $\begin{array}{r}0.00 \\
1632 \\
4995\end{array}$ & $\begin{array}{r}0.001 \\
4189 \\
58\end{array}$ & $\mid \begin{array}{r}0.001 \\
0916 \\
747\end{array}$ & 0 & $\begin{array}{r}0.003 \\
9447 \\
316\end{array}$ & $\mid \begin{array}{r}0.000 \\
5402 \\
74\end{array}$ & 0 & 0 \\
\hline (ii & $\begin{array}{r}1.032 \\
9327 \\
74\end{array}$ & $\begin{array}{r}0.582 \\
9757 \\
9\end{array}$ & $\begin{array}{r}0.597 \\
8383 \\
121\end{array}$ & $\mid \begin{array}{r}0.659 \\
5485 \\
53\end{array}$ & $\begin{array}{r}0.571 \\
8055 \\
67\end{array}$ & $\begin{array}{r}0.589 \\
6144 \\
506\end{array}$ & $\mid \begin{array}{r}0.544 \\
4273 \\
051\end{array}$ & $\begin{array}{r}0.509 \\
0148 \\
614\end{array}$ & $\begin{array}{r}0.523 \\
4967 \\
997\end{array}$ & $\begin{array}{c}0.51 \\
0866 \\
4002\end{array}$ & $\begin{array}{r}0.619 \\
0293 \\
667\end{array}$ & $\mid$\begin{tabular}{|r}
0.562 \\
2005 \\
49
\end{tabular} & $\begin{array}{r}0.534 \\
4640 \\
773\end{array}$ & $\begin{array}{r}0.575 \\
1981 \\
527\end{array}$ & $\mid \begin{array}{r}0.557 \\
4989 \\
873\end{array}$ & $\begin{array}{r}0.636 \\
3706 \\
38\end{array}$ & \begin{tabular}{|r}
0.578 \\
4437 \\
892
\end{tabular} \\
\hline$M$ & $\mid \begin{array}{r}0.004 \\
8328 \\
12\end{array}$ & 0 & 0 & 0 & $\begin{array}{r}0.001 \\
1655 \\
072\end{array}$ & 0 & \begin{tabular}{|r}
0.002 \\
9003 \\
318
\end{tabular} & 0 & $\begin{array}{r}0.004 \\
7724 \\
907\end{array}$ & $\begin{array}{r}0.00 \\
1748 \\
8272\end{array}$ & $\begin{array}{r}0.003 \\
5078 \\
522\end{array}$ & $\begin{array}{r}0.001 \\
1694 \\
646\end{array}$ & 0 & 0 & $\mid \begin{array}{r}0.005 \\
3247 \\
069\end{array}$ & & $\begin{array}{r}0.010 \\
0647 \\
816\end{array}$ \\
\hline $\mathrm{M}$ & $\begin{array}{r}0.411 \\
9605 \\
837\end{array}$ & $\begin{array}{r}0.403 \\
7224 \\
581\end{array}$ & $\begin{array}{r}0.378 \\
7693 \\
014\end{array}$ & $\mid \begin{array}{r}0.380 \\
9267 \\
408\end{array}$ & $\begin{array}{r}0.435 \\
3579 \\
59\end{array}$ & $\begin{array}{r}0.323 \\
7506 \\
93\end{array}$ & $\mid \begin{array}{r}0.399 \\
4502 \\
167\end{array}$ & $\begin{array}{r}0.424 \\
7970 \\
528\end{array}$ & $\mid \begin{array}{r}0.420 \\
2551 \\
425\end{array}$ & $\begin{array}{r}0.40 \\
5945 \\
803\end{array}$ & $\mid \begin{array}{r}0.391 \\
6922 \\
308\end{array}$ & $\mid$\begin{tabular}{||r}
0.404 \\
5160 \\
631
\end{tabular} & $\begin{array}{r}0.411 \\
6362 \\
295\end{array}$ & $\begin{array}{r}0.424 \\
8328 \\
041\end{array}$ & $\mid \begin{array}{r}0.406 \\
5059 \\
561\end{array}$ & $\begin{array}{r}0.377 \\
4254 \\
861\end{array}$ & $\begin{array}{r}0.416 \\
1437 \\
849\end{array}$ \\
\hline C & $\begin{array}{r}0.013 \\
6023 \\
233\end{array}$ & & $\begin{array}{r}0.000 \\
8958 \\
523\end{array}$ & \begin{tabular}{|r}
0.020 \\
3749 \\
771
\end{tabular} & 0 & 0 & $\begin{array}{r}0.000 \\
1467 \\
543\end{array}$ & 0 & $\begin{array}{r}0.000 \\
8834 \\
779\end{array}$ & $\begin{array}{c}0.00 \\
1032 \\
3735\end{array}$ & 0 & $\begin{array}{r}0.004 \\
4380 \\
431\end{array}$ & $\begin{array}{r}0.001 \\
1808 \\
722\end{array}$ & 0 & 0 & $\begin{array}{r}0.001 \\
4993 \\
04\end{array}$ & 0 \\
\hline$N$ & $\begin{array}{r}0.093 \\
7581 \\
895\end{array}$ & $\begin{array}{r}0.099 \\
0229 \\
655\end{array}$ & $\begin{array}{r}0.124 \\
2880 \\
591\end{array}$ & $\mid \begin{array}{r}0.111 \\
7384 \\
827\end{array}$ & $\begin{array}{r}0.192 \\
0954 \\
486\end{array}$ & $\begin{array}{r}0.060 \\
2976 \\
671\end{array}$ & $\mid \begin{array}{r}0.110 \\
7422 \\
481\end{array}$ & $\begin{array}{r}0.112 \\
0374 \\
601\end{array}$ & $\begin{array}{r}0.102 \\
8532 \\
811\end{array}$ & $\begin{array}{r}0.12 \\
1432 \\
975\end{array}$ & $\begin{array}{r}0.101 \\
4445 \\
801\end{array}$ & $\mid \begin{array}{r}0.099 \\
3186 \\
017\end{array}$ & $\begin{array}{r}0.139 \\
4343 \\
727\end{array}$ & \begin{tabular}{|r}
0.121 \\
1866 \\
961
\end{tabular} & {$\left[\begin{array}{r}0.110 \\
4952 \\
32\end{array}\right.$} & $\begin{array}{r}0.103 \\
1002 \\
51\end{array}$ & $\begin{array}{r}0.136 \\
3619 \\
791\end{array}$ \\
\hline K & $\mid \begin{array}{r}1.890 \\
1676 \\
01\end{array}$ & $\begin{array}{r}1.942 \\
6579 \\
605\end{array}$ & $\begin{array}{r}1.918 \\
7324 \\
495 \\
\end{array}$ & $\mid \begin{array}{r}1.905 \\
2145 \\
421\end{array}$ & $\begin{array}{r}1.902 \\
0159 \\
892\end{array}$ & $\begin{array}{r}1.969 \\
7482 \\
013\end{array}$ & \begin{tabular}{|r}
1.939 \\
2003 \\
02
\end{tabular} & $\mid \begin{array}{r}1.940 \\
2571 \\
067\end{array}$ & $\begin{array}{r}1.910 \\
8129 \\
137\end{array}$ & \begin{tabular}{|l}
1.91 \\
8084 \\
9647
\end{tabular} & $\begin{array}{r}1.956 \\
0821 \\
05\end{array}$ & $\mid$\begin{tabular}{||r}
1.926 \\
2642 \\
197
\end{tabular} & $\begin{array}{r}1.925 \\
5377 \\
48\end{array}$ & $\begin{array}{r}1.949 \\
9128 \\
865\end{array}$ & $\mid \begin{array}{r}1.903 \\
8415 \\
054\end{array}$ & $\begin{array}{r}1.905 \\
4782 \\
405\end{array}$ & $\begin{array}{r}1.923 \\
9772 \\
059\end{array}$ \\
\hline A & $\begin{array}{l}14.86 \\
6596 \\
6285\end{array}$ & $\begin{array}{l}14.68 \\
1125 \\
3113\end{array}$ & $\mid \begin{array}{l}14.69 \\
2949 \\
3857\end{array}$ & $\mid \begin{array}{r}14.72 \\
2018 \\
243\end{array}$ & $\mid \begin{array}{l}14.72 \\
6817 \\
6729\end{array}$ & $\begin{array}{c}14.65 \\
1812 \\
7102\end{array}$ & $\begin{array}{l}14.69 \\
0922 \\
2031\end{array}$ & $\begin{array}{r}14.66 \\
9019 \\
5373\end{array}$ & $\mid \begin{array}{r}14.64 \\
5734 \\
0945\end{array}$ & $\begin{array}{c}14.6 \\
5644 \\
1136\end{array}$ & $\begin{array}{l}14.71 \\
5732 \\
4353\end{array}$ & $\mid$\begin{tabular}{||r}
14.66 \\
5997 \\
236
\end{tabular} & $\begin{array}{l}14.69 \\
0460 \\
0144\end{array}$ & $\begin{array}{l}14.69 \\
4704 \\
5076\end{array}$ & $\mid \begin{array}{r}14.64 \\
8973 \\
143\end{array}$ & $\mid \begin{array}{l}14.67 \\
3411 \\
0129\end{array}$ & $\begin{array}{r}14.70 \\
1683 \\
0375\end{array}$ \\
\hline
\end{tabular}

Glaucophane

\begin{tabular}{|c|c|c|c|c|c|c|c|c|c|}
\hline & $1 \mathrm{~m} 8$ & $\operatorname{mos}$ & $\min 10$ & $\operatorname{mi1}$ & $\operatorname{lm} 11$ & $m 1 n$ & $I_{m 15}$ & & \\
\hline $\mathrm{Si}$ & & & & & & & & & \\
\hline 0 & 55.77 & 55.34 & 55.47 & & 54.84 & 54.80 & 55.97 & 56.00 & 56.15 \\
\hline 2 & & & 9 & 54.67 & 9 & & 4 & 4 & \\
\hline $\mathrm{Ti}$ & & & & & & & & & \\
\hline 2 & 0.074 & 0013 & 0 & A & $\ln \cap 0 \wedge$ & $\operatorname{lo} 04$ & llo & 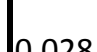 & בח \\
\hline Al & & & & & & & & & \\
\hline & & & & & & & & & \\
\hline 0 & 10.20 & 10,32 & 10.22 & $\mid 10.70$ & 10.35 & |10.67 & & 10.57 & 10.37 \\
\hline 3 & 8 & & & 4 & 2 & & 10.36 & 4 & 9 \\
\hline $\mathrm{Cr}$ & - & 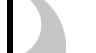 & & & & & & & \\
\hline O & & & & & & & & & \\
\hline 3 & 0.014 & 0 & 0 & 0 & 0 & 0 & 0 & 0 & 0 \\
\hline $\mathrm{Fe}$ & 18.49 & 18.54 & 19.26 & 19.69 & |19.64 & 19.09 & $\mid 18.08$ & 18.59 & 18.60 \\
\hline 0 & & 7 & 2 & 7 & 9 & 6 & 3 & 8 & 2 \\
\hline$M$ & & 1 & & & & & & & \\
\hline 0 & 0.005 & 0 & 0.03 & 0.005 & 0 & 0 & 0.02 & 0 & 0 \\
\hline
\end{tabular}

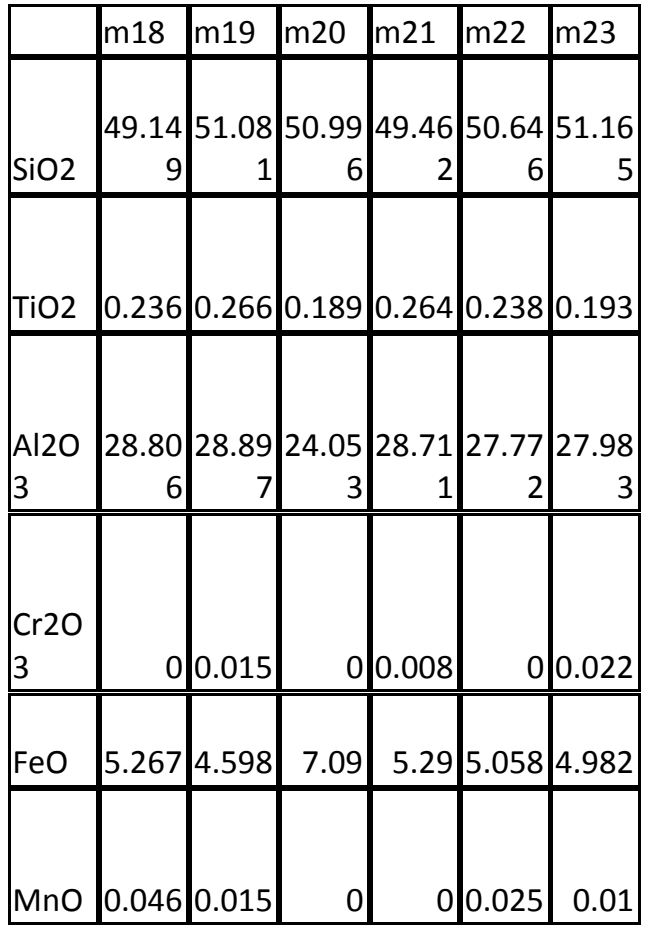

(C) 2017 American Geophysical Union. All rights reserved. 


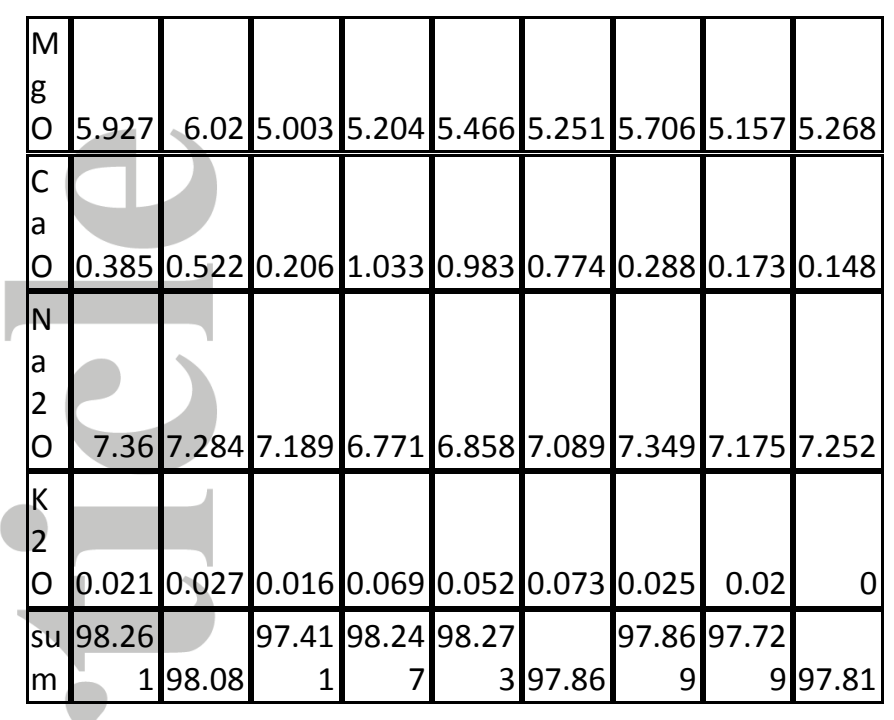

\begin{tabular}{|r||r|r|r||r|r|r||r|r|r|}
\hline & 7.865 & 7.820 & 7.915 & 7.759 & 7.777 & 7.807 & 7.920 & 7.937 & 7.952 \\
$\mathrm{Si}$ & 9103 & 4118 & 0510 & 8424 & 7912 & 9664 & 0684 & 2407 & 6322 \\
\hline \hline & 673 & 988 & 616 & 136 & 574 & 424 & 097 & 531 & 1 \\
\hline & 0.134 & 0.179 & 0.084 & 0.240 & 0.222 & 0.192 & 0.079 & 0.062 & 0.047 \\
$\mathrm{Al}$ & 0896 & 5881 & 9489 & 1575 & 2087 & 0335 & 9315 & 7592 & 3677 \\
\hline & 327 & 012 & 384 & 864 & 426 & 576 & 903 & 469 & 9 \\
\hline
\end{tabular}

\begin{tabular}{|l|r|r|r|r|r|r||r|r|r|}
\hline & 1.562 & 1.539 & 1.634 & 1.550 & 1.507 & 1.599 & 1.647 & 1.703 & 1.684 \\
& 6043 & 0928 & 3879 & 3658 & 7746 & 9885 & 6256 & 3595 & 7797 \\
$\mathrm{Al}$ & 859 & 36 & 371 & 962 & 158 & 004 & 165 & 206 & 052 \\
\hline \hline $\mathrm{Fe}$ & 0.421 & 0.479 & 0.396 & 0.479 & 0.507 & 0.364 & 0.310 & 0.325 & 0.326 \\
(ii & 6808 & 4641 & 2860 & 8411 & 3493 & 5324 & 9096 & 8524 & 0689 \\
$\mathrm{il})$ & 973 & 437 & 86 & 435 & 574 & 619 & 586 & 092 & 681 \\
\hline \hline & 0.007 & 0.001 & & 0.010 & 0.006 & 0.010 & 0.006 & 0.002 & 0.000 \\
& 8497 & 3815 & & 0351 & 8258 & 0717 & 8110 & 9846 & 3195 \\
$\mathrm{Ti}$ & 597 & 882 & 0 & 426 & 92 & 696 & 557 & 981 & 306 \\
\hline \hline & 0.001 & & & & & & & & \\
& 5610 & & & & & & & & \\
$\mathrm{Cr}$ & 101 & 0 & 0 & 0 & 0 & 0 & 0 & 0 & 0 \\
\hline \hline $\mathrm{Fe}$ & 1.759 & 1.711 & 1.901 & 1.857 & 1.822 & 1.910 & 1.828 & 1.878 & 1.876 \\
$(\mathrm{ii}$ & 4928 & 9285 & 6059 & 9572 & 5178 & 2067 & 6097 & 1897 & 6650 \\
$\mathrm{~L}$ & 495 & 663 & 85 & 953 & 75 & 67 & 138 & 704 & 398 \\
\hline \hline $\mathrm{N}$ & 0.000 & & 0.003 & 0.000 & & & 0.002 & & \\
$\mathrm{M}$ & 5972 & & 6248 & 6010 & & & 3966 & & \\
$\mathrm{n}$ & 299 & 0 & 087 & 527 & 0 & 0 & 87 & 0 & 0 \\
\hline \hline $\mathrm{M}$ & 1.246 & 1.268 & 1.064 & 1.101 & 1.155 & 1.115 & 1.203 & 1.089 & 1.112 \\
$\mathrm{M}$ & 2138 & 1328 & 0951 & 1994 & 5322 & 2005 & 6472 & 6136 & 1667 \\
$\mathrm{~g}$ & 676 & 659 & 832 & 697 & 598 & 011 & 683 & 016 & 563 \\
\hline \hline $\mathrm{C}$ & 0.058 & 0.079 & 0.031 & 0.157 & 0.149 & 0.118 & 0.043 & 0.026 & 0.022 \\
$\mathrm{C}$ & 1721 & 0197 & 4857 & 0818 & 3354 & 1269 & 6573 & 2674 & 4534 \\
$\mathrm{a}$ & 912 & 791 & 64 & 72 & 813 & 361 & 124 & 872 & 407 \\
\hline \hline $\mathrm{N}$ & 2.012 & 1.995 & 1.988 & 1.863 & 1.885 & 1.957 & 2.015 & 1.971 & 1.990 \\
$\mathrm{~N}$ & 4214 & 3618 & 3916 & 2236 & 3561 & 8498 & 9473 & 4272 & 9731 \\
$\mathrm{a}$ & 451 & 933 & 372 & 556 & 32 & 578 & 451 & 705 & 742 \\
\hline
\end{tabular}

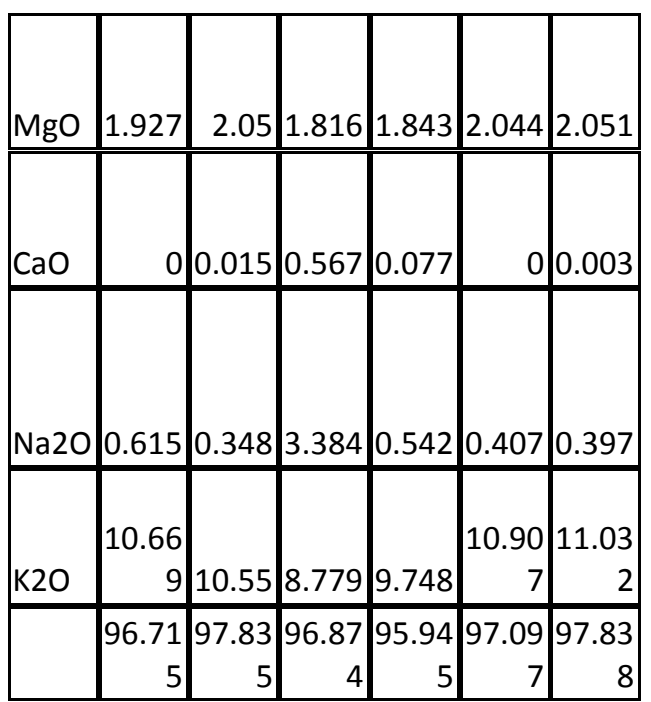

\begin{tabular}{|l||r|r|r|r|r|r|}
\hline & 6.581 & 6.703 & 6.886 & 6.631 & 6.736 & 6.750 \\
& 0898 & 1518 & 0088 & 8994 & 4058 & 3087 \\
$\mathrm{Si}$ & 767 & 071 & 381 & 881 & 439 & 295 \\
\hline \hline & 0.023 & 0.026 & 0.019 & 0.026 & 0.023 & 0.019 \\
& 7617 & 2472 & 1900 & 6166 & 8036 & 1465 \\
$\mathrm{Ti}$ & 424 & 885 & 635 & 463 & 302 & 756 \\
\hline \hline & 4.546 & 4.469 & 3.828 & 4.537 & 4.354 & 4.351 \\
& 5438 & 7961 & 3885 & 6382 & 1715 & 7127 \\
$\mathrm{Al}$ & 356 & 039 & 178 & 699 & 948 & 491 \\
\hline \hline & 0.589 & 0.504 & 0.800 & 0.593 & 0.562 & 0.549 \\
& 7250 & 5355 & 5359 & 0961 & 5551 & 6136 \\
$\mathrm{Fe}$ & 907 & 62 & 69 & 241 & 046 & 78 \\
\hline \hline & 0.005 & 0.001 & & & 0.002 & 0.001 \\
& 2165 & 6670 & & & 8161 & 1173 \\
$\mathrm{Mn}$ & 06 & 54 & 0 & 0 & 893 & 504 \\
\hline \hline & 0.384 & 0.400 & 0.365 & 0.368 & 0.405 & 0.403 \\
& 5758 & 9504 & 4806 & 3059 & 2108 & 3048 \\
$\mathrm{Mg}$ & 215 & 001 & 876 & 402 & 92 & 491 \\
\hline \hline & & 0.002 & 0.082 & 0.011 & & 0.000 \\
& & 1087 & 0231 & 0606 & & 4240 \\
$\mathrm{Ca}$ & 0 & 876 & 495 & 056 & 0 & 273 \\
\hline \hline & 0.159 & 0.088 & 0.885 & 0.140 & 0.104 & 0.101 \\
& 6439 & 5305 & 8417 & 8834 & 9474 & 5396 \\
$\mathrm{Na}$ & 944 & 663 & 639 & 191 & 369 & 117 \\
\hline \hline & 1.822 & 1.765 & 1.512 & 1.667 & 1.850 & 1.856 \\
& 2831 & 9611 & 1174 & 2118 & 5355 & 5811 \\
$\mathrm{~K}$ & 857 & 322 & 639 & 934 & 104 & 109 \\
\hline \hline & 14.11 & 13.96 & 14.37 & 13.97 & 14.04 & 14.03 \\
& 2840 & 2948 & 9586 & 6712 & 0446 & 3748 \\
$\mathrm{Sum}$ & 0531 & 7017 & 4534 & 3869 & 2021 & 6817 \\
\hline
\end{tabular}




\begin{tabular}{|l|r|r|r||r|r|r|r|r|r|}
\hline & 0.003 & 0.004 & 0.002 & 0.012 & 0.009 & 0.013 & 0.004 & 0.003 & \\
& 7779 & 8664 & 9117 & 4928 & 4058 & 2653 & 5122 & 6156 & \\
$K$ & 925 & 938 & 501 & 618 & 907 & 263 & 34 & 761 & 0 \\
\hline$T$ & & & & & & & & & \\
\hline & & & & & & & & & \\
$T$ & 15.07 & 15.07 & 15.02 & 15.03 & 15.04 & 15.08 & 15.06 & 15.00 & 15.01 \\
$A$ & 4371 & 9248 & 2789 & 2798 & 4097 & 9242 & 4116 & 1310 & 3426 \\
$L$ & 6288 & 1661 & 1513 & 3894 & 5041 & 1201 & 8915 & 4337 & 6149 \\
\hline
\end{tabular}
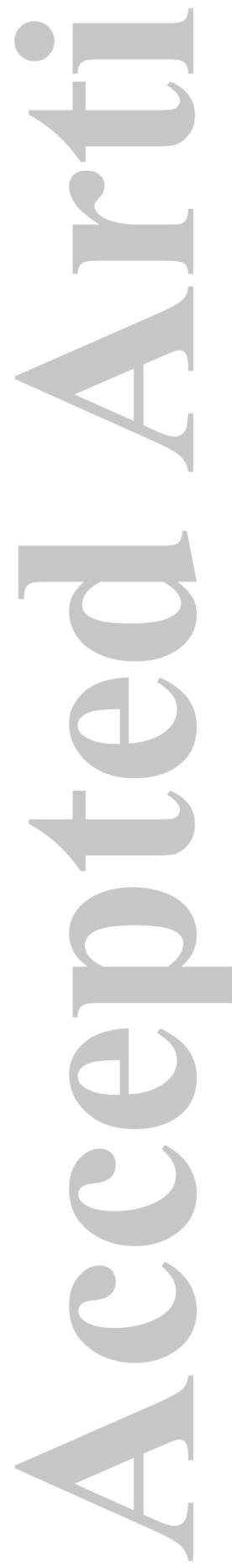

(C) 2017 American Geophysical Union. All rights reserved. 


\begin{tabular}{|c|c|c|c|c|c|c|c|c|c|c|c|c|c|c|c|c|c|c|c|c|c|c|c|}
\hline & 1 & 2 & 3 & 4 & 5 & 6 & 7 & 8 & 9 & 10 & 11 & 12 & 13 & 14 & 15 & 16 & 17 & 18 & 19 & 20 & 21 & 22 & 23 \\
\hline & $\begin{array}{r}55 . \\
26 \\
6\end{array}$ & $\begin{array}{r}55 . \\
55 \\
5\end{array}$ & \begin{tabular}{|r||}
55. \\
53 \\
9
\end{tabular} & $\mid$\begin{tabular}{|r}
55. \\
37 \\
3
\end{tabular} & $\begin{array}{r}55 \\
41 \\
1\end{array}$ & $\begin{array}{r}55 . \\
62 \\
3\end{array}$ & $\begin{array}{r}55 . \\
45 \\
9\end{array}$ & $\begin{array}{r}55 \\
49 \\
9\end{array}$ & $\begin{array}{r}55 . \\
58 \\
2\end{array}$ & $\begin{array}{r}56 . \mid \\
00 \\
2\end{array}$ & $\begin{array}{r}55.3 \\
75\end{array}$ & $\begin{array}{r}55 . \\
66 \\
8\end{array}$ & $\begin{array}{r}54.9 \\
8\end{array}$ & \begin{tabular}{r||r}
56. & 5 \\
03 & \\
6
\end{tabular} & \begin{tabular}{|r||r}
56. & 5 \\
28 & 5 \\
2 & 5
\end{tabular} & \begin{tabular}{r|r}
55. & 53 \\
53 &
\end{tabular} & $\begin{array}{r}56 . \\
12 \\
3\end{array}$ & \begin{tabular}{|r||}
56. \\
05 \\
7
\end{tabular} & $\begin{array}{r}56.2 \\
29\end{array}$ & \begin{tabular}{|r||}
55. \\
69 \\
8
\end{tabular} & $\begin{array}{r}51 . \\
31 \\
4\end{array}$ & $\begin{array}{r}56 . \\
00 \\
4\end{array}$ & $\begin{array}{r}55.7 \\
56\end{array}$ \\
\hline & \begin{tabular}{|r|}
0.1 \\
37
\end{tabular} & $\left|\begin{array}{r}0.0 \\
28\end{array}\right|$ & $\mid \begin{array}{l}0.0 \\
49\end{array}$ & $\mid \begin{array}{r}0.0 \\
62\end{array}$ & $\left|\begin{array}{r|}0.0 \\
28\end{array}\right|$ & & & $\mid \begin{array}{r}0.0 \\
18\end{array}$ & 0 & 49 & $\begin{array}{r}0.07 \\
2\end{array}$ & $\begin{array}{r}0.0 \\
44\end{array}$ & $\begin{array}{r}0.00 \\
5\end{array}$ & \begin{tabular}{r||r}
0.0 \\
57
\end{tabular} & \begin{tabular}{|r||r}
0.0 & 0 \\
08 &
\end{tabular} & \begin{tabular}{r|r}
0.0 & \\
08 &
\end{tabular} & \begin{tabular}{r|}
0.0 \\
26
\end{tabular} & $\begin{array}{r}0.0 \\
08\end{array}$ & 0 & $\begin{array}{r}0.0 \\
05\end{array}$ & $\mid \begin{array}{r}0.0 \\
26\end{array}$ & $\begin{array}{r}0.0 \\
36\end{array}$ & \\
\hline & $\begin{array}{r}11 . \\
25 \\
2\end{array}$ & $\begin{array}{r}13 . \\
53\end{array}$ & \begin{tabular}{|r}
13 \\
48 \\
4
\end{tabular} & $\mid \begin{array}{r}12 . \mid \\
78 \\
6\end{array}$ & \begin{tabular}{|r|}
12. \\
16 \\
8
\end{tabular} & \begin{tabular}{|r||}
13. \\
17 \\
9
\end{tabular} & \begin{tabular}{r|r}
13. \\
52 \\
1
\end{tabular} & \begin{tabular}{|r|r|}
13. \\
99 \\
7
\end{tabular} & $\begin{array}{r}13 . \\
74 \\
2\end{array}$ & $\begin{array}{r}13 . \mid \\
85 \\
2\end{array}$ & $\begin{array}{r}12.6 \\
62\end{array}$ & $\begin{array}{r}63 \\
5 \\
\end{array}$ & $\begin{array}{r}11.2 \\
31\end{array}$ & \begin{tabular}{r||}
12. \\
84 \\
84
\end{tabular} & \begin{tabular}{|r||r}
14. & \\
34 & 1 \\
5 &
\end{tabular} & $\begin{array}{r}12 . \\
55\end{array}$ & $\begin{array}{r}13 . \\
40 \\
3\end{array}$ & \begin{tabular}{|r||}
13. \\
47 \\
1
\end{tabular} & \begin{tabular}{r||}
12.7 \\
82
\end{tabular} & \begin{tabular}{|r||}
12. \\
44 \\
3
\end{tabular} & \begin{tabular}{|r|}
30. \\
50 \\
7
\end{tabular} & $\begin{array}{r}14 . \\
23 \\
7\end{array}$ & $\begin{array}{r}13.5 \\
37\end{array}$ \\
\hline & $\begin{array}{r}15 . \\
28 \\
6\end{array}$ & \begin{tabular}{|r|}
13. \\
65 \\
3
\end{tabular} & \begin{tabular}{|r}
13. \\
68 \\
5
\end{tabular} & \begin{tabular}{|r||}
14. \\
15 \\
9
\end{tabular} & \begin{tabular}{|r|r|}
14. \\
91 \\
5
\end{tabular} & $\begin{array}{r}14 . \\
20 \\
9\end{array}$ & $\begin{array}{r}14 . \\
14 \\
3\end{array}$ & \begin{tabular}{r|r|}
13. & 1 \\
29 & \\
5 &
\end{tabular} & $\begin{array}{r}13 . \\
49 \\
3\end{array}$ & $\begin{array}{r}12 . \\
84 \\
9\end{array}$ & $\begin{array}{r}14.4 \\
12\end{array}$ & $\begin{array}{r}13 . \\
51 \\
6\end{array}$ & $\begin{array}{r} \\
15.0 \\
72\end{array}$ & \begin{tabular}{|r||}
14. \\
13 \\
8
\end{tabular} & \begin{tabular}{|r||}
12. \\
12. \\
93
\end{tabular} & \begin{tabular}{r|r}
14. & \\
47 & \\
4 &
\end{tabular} & $\begin{array}{r}13 . \\
91 \\
3\end{array}$ & \begin{tabular}{|r||}
13. \\
98 \\
8
\end{tabular} & $\begin{array}{r}14.6 \\
68\end{array}$ & $\begin{array}{r}14 . \mid \\
51\end{array}$ & $\mid$\begin{tabular}{|r|}
6.1 \\
47
\end{tabular} & $\begin{array}{r}13 . \\
22 \\
9\end{array}$ & $\begin{array}{r}13.8 \\
09\end{array}$ \\
\hline & $\begin{array}{r}0.0 \\
65\end{array}$ & $\left|\begin{array}{r}0.1 \\
81\end{array}\right|$ & $\mid \begin{array}{r}0.0 \\
55\end{array}$ & $\begin{array}{r}0.0 \\
86\end{array}$ & $\mid \begin{array}{l}0.0 \\
75\end{array}$ & \begin{tabular}{|r||}
0.0 \\
65
\end{tabular} & \begin{tabular}{r||}
0.1 \\
01
\end{tabular} & \begin{tabular}{r|c}
0.0 & 0 \\
96
\end{tabular} & $\begin{array}{r}0.1 \\
16\end{array}$ & $\begin{array}{r}0.0 \\
2\end{array}$ & $\begin{array}{r}0.10 \\
1\end{array}$ & $\begin{array}{r}0.0 \\
4\end{array}$ & 이 & \begin{tabular}{|r|r}
0.0 & 0 \\
1 &
\end{tabular} & \begin{tabular}{|r|r|r|}
0.0 & 0 \\
3 &
\end{tabular} & \begin{tabular}{r|r}
0.0 & \\
65 &
\end{tabular} & \begin{tabular}{r|r}
0.0 \\
45
\end{tabular} & \begin{tabular}{|r||}
0.1 \\
56
\end{tabular} & \begin{tabular}{r||}
0.13 \\
1
\end{tabular} & \begin{tabular}{r|r}
0.1 \\
06
\end{tabular} & $\left|\begin{array}{l|}0.0 \\
25\end{array}\right|$ & $\begin{array}{r}0.0 \\
6\end{array}$ & $\begin{array}{r}0.12 \\
6\end{array}$ \\
\hline & $\begin{array}{r}1.7 \\
34 \\
\end{array}$ & $\begin{array}{r}0.9 \\
42\end{array}$ & \begin{tabular}{|r||}
1.2 \\
7
\end{tabular} & \begin{tabular}{||r|}
1.2 \\
46
\end{tabular} & \begin{tabular}{r|r}
1.1 & 1 \\
62 &
\end{tabular} & \begin{tabular}{|r|r}
1.0 & \\
7 &
\end{tabular} & $\begin{array}{r}0.8 \\
99\end{array}$ & \begin{tabular}{|r|c}
1.1 & \\
09
\end{tabular} & $\begin{array}{r}0.9 \\
79\end{array}$ & $\begin{array}{r}1.1 \\
11\end{array}$ & $\begin{array}{r}1.25 \\
9\end{array}$ & $\begin{array}{r}1.0 \\
41\end{array}$ & 1.4 & 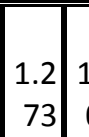 & \begin{tabular}{|r|r}
1.1 & 1 \\
03 &
\end{tabular} & \begin{tabular}{r|r}
1.3 \\
01
\end{tabular} & \begin{tabular}{r|r}
1.0 \\
31
\end{tabular} & \begin{tabular}{|r||}
1.0 \\
93
\end{tabular} & $\begin{array}{r}1.08 \\
7\end{array}$ & $\mid$\begin{tabular}{|r||}
1.3 \\
99
\end{tabular} & $\mid \begin{array}{r}0.4 \\
16\end{array}$ & $\begin{array}{r}0.8 \\
54\end{array}$ & $\begin{array}{r}0.98 \\
9\end{array}$ \\
\hline & $\begin{array}{r}3.8 \\
93\end{array}$ & \begin{tabular}{|r|}
2.3 \\
09 \\
\end{tabular} & $\mid \begin{array}{r}3.1 \\
2\end{array}$ & \begin{tabular}{||c||}
2.9 \\
78
\end{tabular} & \begin{tabular}{r|r}
3.0 & 2 \\
11 &
\end{tabular} & \begin{tabular}{|r|r}
2.6 \\
62
\end{tabular} & $\begin{array}{r}2.3 \\
56\end{array}$ & \begin{tabular}{|r|r}
2.6 & 2 \\
52 &
\end{tabular} & $\begin{array}{r}2.4 \\
15\end{array}$ & $\begin{array}{r}2.7 \\
13\end{array}$ & $\begin{array}{r}2.97 \\
4\end{array}$ & $\begin{array}{r}2.5 \\
96\end{array}$ & $\begin{array}{r}3.47 \\
9\end{array}$ & \begin{tabular}{|r||r|}
2.7 & 2 \\
89 &
\end{tabular} & \begin{tabular}{|r|r}
2.3 & 3 \\
14 & 5
\end{tabular} & \begin{tabular}{r|r}
3.1 & 2 \\
51
\end{tabular} & \begin{tabular}{r|r}
2.6 \\
19
\end{tabular} & \begin{tabular}{|r||}
2.4 \\
98
\end{tabular} & 2.66 & $\mid$\begin{tabular}{r||}
3.3 \\
35
\end{tabular} & \begin{tabular}{|r|}
1.0 \\
32
\end{tabular} & $\begin{array}{r}2.3 \\
49\end{array}$ & $\begin{array}{r}2.29 \\
2 \\
\end{array}$ \\
\hline & $\begin{array}{r}11 . \\
87 \\
9\end{array}$ & $\begin{array}{r}12 . \\
94 \\
2\end{array}$ & $\mid \begin{array}{r}12 . \mid \\
68 \\
8\end{array}$ & $\mid$\begin{tabular}{||r||}
12. \\
70 \\
6
\end{tabular} & \begin{tabular}{|r|} 
\\
12. \\
12
\end{tabular} & $\begin{array}{r}12 . \mid \\
82 \\
4\end{array}$ & $\begin{array}{r}12 . \mid \\
8\end{array}$ & $\begin{array}{r}12 . \\
55 \\
8\end{array}$ & $\begin{array}{r}12 . \\
72 \\
3\end{array}$ & $\begin{array}{r}12 . \mid \\
62\end{array}$ & $\begin{array}{r}12.4 \\
63\end{array}$ & $\begin{array}{r}12 . \\
68 \\
6\end{array}$ & $\begin{array}{r}11.8 \\
37\end{array}$ & \begin{tabular}{|r||}
13. \\
00 \\
7
\end{tabular} & \begin{tabular}{r||}
13 \\
11
\end{tabular} & $\begin{array}{r}12 . \\
13 \\
8\end{array}$ & $\begin{array}{r}12 . \\
53 \\
8\end{array}$ & $\begin{array}{r}12 . \\
75 \\
3\end{array}$ & \begin{tabular}{r||}
12.5 \\
7
\end{tabular} & \begin{tabular}{|r||}
12. \\
91 \\
2
\end{tabular} & $\begin{array}{r}9.0 \\
98\end{array}$ & $\begin{array}{r}13 . \\
02 \\
2\end{array}$ & $\begin{array}{r}13.0 \\
15\end{array}$ \\
\hline & $\begin{array}{r}0.0 \\
33\end{array}$ & $\begin{array}{r}0.0 \\
19\end{array}$ & \begin{tabular}{|r|} 
\\
0.0 \\
13
\end{tabular} & $\mid$\begin{tabular}{|c||}
0.0 \\
24
\end{tabular} & $\left|\begin{array}{r|c}0.0 & 0 \\
28\end{array}\right|$ & \begin{tabular}{|r|r}
0.0 \\
28
\end{tabular} & $\begin{array}{r}0.0 \\
25\end{array}$ & 0 & $\mid$\begin{tabular}{r|c}
0.0 \\
04
\end{tabular} & \begin{tabular}{r||}
0.0 \\
24
\end{tabular} & $\begin{array}{r}0.01 \\
6\end{array}$ & $\begin{array}{r}0.0 \\
24\end{array}$ & 0 & \begin{tabular}{|r|r|r}
0.0 & 0 \\
2
\end{tabular} & \begin{tabular}{|r|}
0.0 \\
12
\end{tabular} \mid & & \begin{tabular}{r|r}
0.0 \\
11
\end{tabular} & \begin{tabular}{r||}
0.0 \\
03
\end{tabular} & \begin{tabular}{r||}
0.01 \\
1
\end{tabular} & $\mid \begin{array}{r}0.0 \\
11\end{array}$ & $\mid \begin{array}{r}0.8 \\
98\end{array}$ & $\begin{array}{r}0.0 \\
03\end{array}$ & 0 \\
\hline & $\begin{array}{r}0.0 \\
4\end{array}$ & 0 & 0 & $\mid$\begin{tabular}{|c||}
0.0 \\
24
\end{tabular} & 0 & 0 & 0 & 0 & 이 & 0 & 0 & $\begin{array}{r}0.0 \\
43\end{array} \mid$ & $\begin{array}{r}0.00 \\
6\end{array}$ & 0 & 0 & $\begin{array}{r}0.0 \\
34\end{array}$ & 0 & 0 & $\begin{array}{r}0.00 \\
3\end{array}$ & $\mid \begin{array}{r}0.0 \\
18\end{array}$ & $\left|\begin{array}{c}0.0 \\
21\end{array}\right|$ & 이 & 0 \\
\hline & $\begin{array}{r}99 . \\
58 \\
5\end{array}$ & \begin{tabular}{|r|}
99. \\
15 \\
9
\end{tabular} & \begin{tabular}{|r||}
99. \\
90 \\
3
\end{tabular} & \begin{tabular}{|r|}
99. \\
44 \\
4 \\
\end{tabular} & \begin{tabular}{|r|r|}
98. & 9 \\
91 & \\
8
\end{tabular} & \begin{tabular}{r||r|}
99. & \\
70 & \\
6
\end{tabular} & \begin{tabular}{r|}
99. \\
30 \\
4
\end{tabular} & \begin{tabular}{r|r}
99. & 9 \\
22 & 4
\end{tabular} & $\begin{array}{r}99 . \\
05 \\
4 \\
\end{array}$ & $\begin{array}{r}99 . \\
24\end{array}$ & $\begin{array}{r}99.3 \\
34\end{array}$ & \begin{tabular}{|r|}
99. \\
29 \\
3
\end{tabular} & $\begin{array}{r}98.0 \\
1\end{array}$ & \begin{tabular}{|r||}
10 \\
0.1 \\
7
\end{tabular} & \begin{tabular}{|r|r}
10 & 9 \\
0.1 & \\
34 & \\
\end{tabular} & $\begin{array}{r}99 . \\
25 \\
5\end{array}$ & $\begin{array}{r}99 . \\
70 \\
9\end{array}$ & \begin{tabular}{|r|}
10 \\
0.0 \\
27 \\
\end{tabular} & $\begin{array}{r}100 . \\
141\end{array}$ & \begin{tabular}{|r|}
10 \\
0.4 \\
37 \\
\end{tabular} & \begin{tabular}{|r|}
99. \\
48 \\
4 \\
\end{tabular} & $\begin{array}{r}99 . \\
79 \\
4\end{array}$ & $\begin{array}{r}99.5 \\
24\end{array}$ \\
\hline
\end{tabular}

\begin{tabular}{|r|r|r||r||r||r|r||r||r|r|r||r|r|r|r||r||r|r|r|r||r|r|r|r|}
\hline & 2.0 & 2.0 & 2.0 & 2.0 & 2.0 & 2.0 & 2.0 & 2.0 & 2.0 & & 2.0 & & 2.0 & & 2.0 & 2.0 & 2.0 & & 2.0 & 1.7 & 2.0 & \\
& 49 & 2.0 & 31 & 41 & 56 & 41 & 41 & 34 & 43 & 47 & & 42 & & 47 & 2.0 & 49 & 51 & 45 & & 39 & 80 & 39 \\
& 32 & 43 & 60 & 20 & 86 & 85 & 14 & 93 & 15 & 09 & & 34 & & 64 & 39 & 87 & 30 & 35 & & 85 & 60 & 46 \\
& 08 & 97 & 64 & 11 & 58 & 58 & 37 & 97 & 97 & 44 & 2.04 & 14 & 2.06 & 44 & 01 & 61 & 88 & 84 & 2.05 & 90 & 47 & 32 & 2.04 \\
$\mathrm{~S}$ & 93 & 98 & 17 & 32 & 49 & 39 & 12 & 45 & 53 & 29 & 4162 & 16 & 5329 & 43 & 72 & 34 & 28 & 55 & 5921 & 71 & 18 & 81 & 4272 \\
$\mathrm{i}$ & 7 & 9 & 9 & 7 & 1 & 6 & 3 & 3 & 2 & 4 & 9361 & 6 & 5241 & 9 & 29 & 5 & 9 & 5 & 6956 & 9 & 4 & 1 & 313 \\
\hline \hline & 0.0 & 0.0 & 0.0 & 0.0 & 0.0 & 0.0 & & 0.0 & & 0.0 & 0.00 & 0.0 & 0.00 & 0.0 & 0.0 & 0.0 & 0.0 & 0.0 & & 0.0 & 0.0 & 0.0 & \\
$\mathrm{~T}$ & 03 & 00 & 01 & 01 & 00 & 01 & & 00 & & 01 & 1998 & 01 & 0141 & 01 & 00 & 00 & 00 & 00 & & 00 & 00 & 00 & \\
$\mathrm{i}$ & 81 & 77 & 34 & 71 & 78 & 26 & 0 & 49 & 0 & 34 & 561 & 21 & 2335 & 56 & 21 & 22 & 71 & 21 & 0 & 13 & 67 & 98 & 0 \\
\hline
\end{tabular}




\begin{tabular}{|c|c|c|c|c|c|c|c|c|c|c|c|c|c|c|c|c|c|c|c|c|c|c|c|}
\hline & $\begin{array}{r}99 \\
32 \\
1\end{array}$ & $\begin{array}{r}46 \\
30 \\
6 \\
\end{array}$ & \begin{tabular}{|r||}
77 \\
85 \\
4
\end{tabular} & \begin{tabular}{|r|}
85 \\
51 \\
6 \\
\end{tabular} & $\begin{array}{r}15 \\
39 \\
9\end{array}$ & \begin{tabular}{|r||}
97 \\
30 \\
8
\end{tabular} & & $\begin{array}{r}62 \\
74 \\
6\end{array}$ & & $\begin{array}{r}68 \\
32 \\
4\end{array}$ & & $\begin{array}{r}38 \\
31 \\
9\end{array}$ & & \begin{tabular}{r||}
61 \\
93 \\
5
\end{tabular} & \begin{tabular}{|r||}
79 \\
33 \\
8 \\
\end{tabular} & \begin{tabular}{||r|}
20 \\
45 \\
4
\end{tabular} & \begin{tabular}{|r|}
45 \\
73 \\
1
\end{tabular} & \begin{tabular}{|l||}
94 \\
89
\end{tabular} & & $\begin{array}{r}76 \\
93 \\
6 \\
6\end{array}$ & $\mid$\begin{tabular}{|r}
84 \\
03 \\
6 \\
\end{tabular} & $\begin{array}{r}57 \\
85 \\
6\end{array}$ & \\
\hline & $\begin{array}{r}0.4 \\
91 \\
80 \\
95 \\
40 \\
3 \\
\end{array}$ & \begin{tabular}{r|}
0.5 \\
86 \\
76 \\
81 \\
79 \\
1 \\
\end{tabular} & \begin{tabular}{|r||}
0.5 \\
81 \\
40 \\
07 \\
05 \\
6
\end{tabular} & \begin{tabular}{|r|}
0.5 \\
55 \\
56 \\
86 \\
58 \\
6
\end{tabular} & \begin{tabular}{|r|}
0.5 \\
32 \\
40 \\
78 \\
75 \\
5
\end{tabular} & \begin{tabular}{|r|}
0.5 \\
70 \\
25 \\
40 \\
99 \\
8
\end{tabular} & \begin{tabular}{|r|}
0.5 \\
86 \\
57 \\
78 \\
40 \\
4 \\
\end{tabular} & \begin{tabular}{|r|}
0.6 \\
04 \\
94 \\
60 \\
55 \\
6 \\
\end{tabular} & $\begin{array}{r}0.5 \\
95 \\
43 \\
36 \\
71 \\
1\end{array}$ & $\begin{array}{r}0.5 \\
96 \\
84 \\
57 \\
59 \\
4\end{array}$ & \begin{tabular}{||c|} 
\\
\\
0.55 \\
0959 \\
1119 \\
\end{tabular} & \begin{tabular}{|r|}
0.5 \\
89 \\
64 \\
84 \\
46 \\
4
\end{tabular} & \begin{tabular}{|} 
\\
\\
0.49 \\
7299 \\
8583 \\
\end{tabular} & \begin{tabular}{r||}
0.5 \\
53 \\
05 \\
42 \\
51 \\
\end{tabular} & \begin{tabular}{|r|}
0.6 \\
12 \\
58 \\
62 \\
10 \\
7 \\
\end{tabular} & \begin{tabular}{|r}
0.5 \\
46 \\
04 \\
40 \\
50 \\
5 \\
\end{tabular} & \begin{tabular}{|r|}
0.5 \\
77 \\
44 \\
08 \\
17 \\
4
\end{tabular} & \begin{tabular}{|r|}
0.5 \\
79 \\
36 \\
82 \\
67 \\
9 \\
\end{tabular} & $\mid \begin{array}{c} \\
\\
0.55 \\
0884 \\
1959 \\
\end{array}$ & \begin{tabular}{|r|}
0.5 \\
37 \\
15 \\
66 \\
47 \\
9 \\
\end{tabular} & \begin{tabular}{||r}
1.2 \\
47 \\
80 \\
41 \\
98 \\
3 \\
\end{tabular} & \begin{tabular}{|r|}
0.6 \\
11 \\
12 \\
58 \\
00 \\
5
\end{tabular} & $\begin{array}{c}0.58 \\
5039 \\
0519\end{array}$ \\
\hline & $\begin{array}{r}0.4 \\
73 \\
96 \\
79 \\
13 \\
5\end{array}$ & \begin{tabular}{|r|}
0.4 \\
20 \\
03 \\
42 \\
53 \\
7 \\
\end{tabular} & \begin{tabular}{|c||} 
\\
0.4 \\
18 \\
59 \\
06 \\
02
\end{tabular} & \begin{tabular}{|r||}
0.4 \\
36 \\
43 \\
89 \\
28 \\
2
\end{tabular} & $\mid \begin{array}{r}0.4 \\
62 \\
95 \\
24 \\
52 \\
1\end{array}$ & \begin{tabular}{|r|}
0.4 \\
36 \\
15 \\
14 \\
63 \\
1
\end{tabular} & \begin{tabular}{|r|}
0.4 \\
35 \\
25 \\
74 \\
78 \\
7 \\
\end{tabular} & $\mid$\begin{tabular}{||r|}
0.4 \\
07 \\
62 \\
22 \\
57 \\
2
\end{tabular} & \begin{tabular}{|r|}
0.4 \\
14 \\
74 \\
37 \\
28 \\
1
\end{tabular} & $\begin{array}{r}0.3 \\
92 \\
74 \\
15 \\
22 \\
9 \\
9\end{array}$ & \begin{tabular}{||c|} 
\\
\\
0.44 \\
4865 \\
9594
\end{tabular} & $\begin{array}{r}0.4 \\
14 \\
64 \\
27 \\
35 \\
1\end{array}$ & \begin{tabular}{|r|} 
\\
\\
0.47 \\
3433 \\
1399 \\
\end{tabular} & \begin{tabular}{r|}
0.4 \\
31 \\
99 \\
48 \\
30 \\
2 \\
\end{tabular} & \begin{tabular}{|r|}
0.3 \\
91 \\
69 \\
95 \\
29 \\
6 \\
\end{tabular} & \begin{tabular}{||r|}
0.4 \\
46 \\
74 \\
57 \\
02 \\
1 \\
\end{tabular} & \begin{tabular}{|r|}
0.4 \\
25 \\
22 \\
04 \\
16 \\
1
\end{tabular} & \begin{tabular}{|r|}
0.4 \\
26 \\
77 \\
43 \\
93 \\
4
\end{tabular} & $\mid$\begin{tabular}{|c} 
\\
\\
0.44 \\
8456 \\
4374
\end{tabular} & \begin{tabular}{|r|}
0.4 \\
44 \\
35 \\
60 \\
80 \\
5 \\
\end{tabular} & \begin{tabular}{||r|}
0.1 \\
78 \\
36 \\
02 \\
26 \\
3 \\
\end{tabular} & \begin{tabular}{|r|}
0.4 \\
02 \\
83 \\
48 \\
28 \\
2
\end{tabular} & $\begin{array}{l} \\
0.42 \\
3362 \\
6281\end{array}$ \\
\hline & $\begin{array}{r}0.0 \\
02 \\
04 \\
12 \\
86 \\
8 \\
\end{array}$ & \begin{tabular}{|r|}
0.0 \\
05 \\
63 \\
98 \\
91 \\
9 \\
\end{tabular} & \begin{tabular}{|r|}
0.0 \\
01 \\
70 \\
38 \\
95 \\
5 \\
\end{tabular} & \begin{tabular}{|r|}
0.0 \\
02 \\
68 \\
48 \\
80 \\
\end{tabular} & \begin{tabular}{|r|}
0.0 \\
02 \\
35 \\
78 \\
16 \\
4 \\
\end{tabular} & \begin{tabular}{r||}
0.0 \\
02 \\
02 \\
07 \\
97 \\
4 \\
\end{tabular} & \begin{tabular}{|r||}
0.0 \\
03 \\
14 \\
81 \\
95
\end{tabular} & \begin{tabular}{|r|}
0.0 \\
02 \\
98 \\
10 \\
98 \\
8 \\
\end{tabular} & $\begin{array}{r}0.0 \\
03 \\
61 \\
13 \\
10 \\
9\end{array}$ & \begin{tabular}{r|}
0.0 \\
00 \\
61 \\
91 \\
60 \\
3 \\
\end{tabular} & \begin{tabular}{|r|} 
\\
\\
0.00 \\
3157 \\
6347
\end{tabular} & $\begin{array}{r}0.0 \\
01 \\
24 \\
28 \\
57 \\
8 \\
\end{array}$ & 0 & \begin{tabular}{|r|}
0.0 \\
00 \\
30 \\
94 \\
75 \\
4 \\
\end{tabular} & \begin{tabular}{|r|}
0.0 \\
00 \\
92 \\
04 \\
73 \\
7 \\
\end{tabular} & \begin{tabular}{||r|}
0.0 \\
02 \\
03 \\
19 \\
86 \\
2 \\
\end{tabular} & $\begin{array}{r}0.0 \\
01 \\
39 \\
29 \\
68 \\
9 \\
\end{array}$ & \begin{tabular}{r|}
0.0 \\
04 \\
82 \\
06 \\
20 \\
2 \\
\end{tabular} & $\mid$\begin{tabular}{|} 
\\
0.00 \\
4056 \\
5445
\end{tabular} & \begin{tabular}{|r|}
0.0 \\
03 \\
28 \\
77 \\
98 \\
3 \\
\end{tabular} & \begin{tabular}{|r|}
0.0 \\
00 \\
73 \\
47 \\
00 \\
6 \\
\end{tabular} & $\begin{array}{r}0.0 \\
01 \\
85 \\
04 \\
90 \\
4 \\
\end{array}$ & $\mid \begin{array}{c}0.00 \\
3912 \\
5187\end{array}$ \\
\hline & \begin{tabular}{|r|}
0.0 \\
95 \\
83 \\
36 \\
77 \\
5
\end{tabular} & \begin{tabular}{|r|}
0.0 \\
51 \\
65 \\
60 \\
85 \\
9 \\
\end{tabular} & \begin{tabular}{|r|}
0.0 \\
69 \\
24 \\
08 \\
46 \\
2 \\
\end{tabular} & $\mid \begin{array}{c}0.0 \\
68 \\
45 \\
77 \\
96\end{array}$ & \begin{tabular}{|r|}
0.0 \\
64 \\
28 \\
84 \\
91 \\
2 \\
\end{tabular} & $\begin{array}{r}0.0 \\
58 \\
54 \\
25 \\
41 \\
4\end{array}$ & $\mid \begin{array}{c}0.0 \\
49 \\
31 \\
49 \\
23\end{array}$ & \begin{tabular}{|r|}
0.0 \\
60 \\
60 \\
59 \\
22 \\
8 \\
\end{tabular} & \begin{tabular}{|r|}
0.0 \\
53 \\
63 \\
74 \\
31 \\
5 \\
\end{tabular} & $\begin{array}{r}0.0 \\
60 \\
52 \\
92 \\
82 \\
2 \\
\end{array}$ & \begin{tabular}{|c} 
\\
0.06 \\
9269 \\
9105 \\
\end{tabular} & \begin{tabular}{|r|}
0.0 \\
56 \\
92 \\
33 \\
67 \\
1
\end{tabular} & \begin{tabular}{|r|} 
\\
\\
0.07 \\
8384 \\
4255 \\
\end{tabular} & \begin{tabular}{|r||}
0.0 \\
69 \\
33 \\
18 \\
75 \\
8 \\
\end{tabular} & \begin{tabular}{|r|}
0.0 \\
59 \\
55 \\
85 \\
35 \\
7 \\
\end{tabular} & \begin{tabular}{|l|} 
\\
0.0 \\
71 \\
57 \\
52 \\
85 \\
\end{tabular} & \begin{tabular}{|r|}
0.0 \\
56 \\
16 \\
50 \\
25 \\
8 \\
\end{tabular} & $\begin{array}{r}0.0 \\
59 \\
43 \\
97 \\
35 \\
2 \\
\end{array}$ & $\mid$\begin{tabular}{|c} 
\\
\\
0.05 \\
9236 \\
9759
\end{tabular} & \begin{tabular}{|r|}
0.0 \\
76 \\
36 \\
51 \\
84 \\
2 \\
\end{tabular} & \begin{tabular}{|r|}
0.0 \\
21 \\
51 \\
50 \\
37 \\
5 \\
\end{tabular} & \begin{tabular}{|c|}
0.0 \\
46 \\
35
\end{tabular} & $\begin{array}{r}0.05 \\
4045 \\
6264 \\
\end{array}$ \\
\hline & $\begin{array}{r}0.1 \\
54 \\
65 \\
29 \\
67 \\
6\end{array}$ & \begin{tabular}{|r|}
0.0 \\
91 \\
01 \\
21 \\
38 \\
4 \\
\end{tabular} & \begin{tabular}{|l|}
0.1 \\
22 \\
26 \\
94 \\
71 \\
\end{tabular} & \begin{tabular}{|c||}
0.1 \\
17 \\
60 \\
73 \\
21
\end{tabular} & \begin{tabular}{|r|}
0.1 \\
19 \\
74 \\
09 \\
37 \\
5
\end{tabular} & \begin{tabular}{|r|}
0.1 \\
04 \\
68 \\
89 \\
00 \\
4
\end{tabular} & \begin{tabular}{|c||}
0.0 \\
92 \\
89 \\
63 \\
72
\end{tabular} & $\mid$\begin{tabular}{||r|}
0.1 \\
04 \\
17 \\
45 \\
98 \\
4
\end{tabular} & $\begin{array}{r}0.0 \\
95 \\
10 \\
58 \\
45 \\
2\end{array}$ & $\begin{array}{r}0.1 \\
06 \\
24 \\
44 \\
00 \\
9\end{array}$ & $\begin{array}{r}0.11 \\
7615 \\
5256\end{array}$ & \begin{tabular}{|r|}
0.1 \\
02 \\
03 \\
50 \\
38 \\
6
\end{tabular} & \begin{tabular}{|} 
\\
\\
0.14 \\
0010 \\
6158
\end{tabular} & \begin{tabular}{r|}
0.1 \\
09 \\
18 \\
37 \\
11 \\
7
\end{tabular} & \begin{tabular}{|r||}
0.0 \\
89 \\
81 \\
24 \\
71 \\
4
\end{tabular} & $\mid$\begin{tabular}{|r}
0.1 \\
24 \\
60 \\
60 \\
08 \\
8
\end{tabular} & \begin{tabular}{|r|}
0.1 \\
02 \\
55 \\
28 \\
15 \\
7
\end{tabular} & \begin{tabular}{|r|}
0.0 \\
97 \\
64 \\
58 \\
81 \\
8 \\
\end{tabular} & $\mid \begin{array}{r}0.10 \\
4195 \\
6925\end{array}$ & \begin{tabular}{||r||}
0.1 \\
30 \\
85 \\
13 \\
84 \\
1 \\
1
\end{tabular} & \begin{tabular}{|c|} 
\\
0.0 \\
38 \\
36 \\
48 \\
29 \\
\end{tabular} & $\begin{array}{r}0.0 \\
91 \\
64 \\
35 \\
23 \\
7\end{array}$ & $\begin{array}{l}0.09 \\
0029\end{array}$ \\
\hline & \begin{tabular}{|r|}
0.8 \\
53 \\
93 \\
76 \\
29 \\
4 \\
\end{tabular} & \begin{tabular}{|r|}
0.9 \\
23 \\
10 \\
09 \\
46 \\
2 \\
\end{tabular} & \begin{tabular}{|r|}
0.8 \\
99 \\
76 \\
48 \\
52 \\
2 \\
\end{tabular} & \begin{tabular}{|r|}
0.9 \\
08 \\
01 \\
06 \\
28 \\
8 \\
\end{tabular} & \begin{tabular}{|r|}
0.8 \\
72 \\
18 \\
16 \\
26 \\
2 \\
\end{tabular} & $\begin{array}{r}0.9 \\
12 \\
61 \\
69 \\
09 \\
1 \\
\end{array}$ & \begin{tabular}{||c||}
0.9 \\
13 \\
28 \\
40 \\
07 \\
3 \\
\end{tabular} & \begin{tabular}{|r|r|}
0.8 \\
92 \\
64 \\
99 \\
99 \\
4 \\
\end{tabular} & \begin{tabular}{|r|}
0.9 \\
06 \\
67 \\
57 \\
83 \\
8 \\
\end{tabular} & $\begin{array}{r}0.8 \\
94 \\
30 \\
98 \\
78 \\
8 \\
\end{array}$ & \begin{tabular}{|r|} 
\\
\\
0.89 \\
1905 \\
2069 \\
\end{tabular} & \begin{tabular}{|l|}
0.9 \\
02 \\
28 \\
09 \\
06 \\
\end{tabular} & \begin{tabular}{|r|} 
\\
0.86 \\
2026 \\
4654 \\
\end{tabular} & \begin{tabular}{|r||}
0.9 \\
21 \\
42 \\
26 \\
73 \\
8 \\
\end{tabular} & \begin{tabular}{|r|}
0.9 \\
20 \\
76 \\
41 \\
44 \\
9 \\
\end{tabular} & \begin{tabular}{|r|}
0.8 \\
68 \\
58 \\
06 \\
10 \\
8 \\
\end{tabular} & \begin{tabular}{|r|}
0.8 \\
88 \\
40 \\
86 \\
34 \\
8 \\
\end{tabular} & \begin{tabular}{|r||}
0.9 \\
02 \\
08 \\
25 \\
3 \\
\end{tabular} & \begin{tabular}{|r}
0.89 \\
0996 \\
1374 \\
\end{tabular} & \begin{tabular}{|r|}
0.9 \\
16 \\
74 \\
47 \\
14 \\
6 \\
\end{tabular} & \begin{tabular}{|r}
0.6 \\
12 \\
02 \\
88 \\
80 \\
9 \\
\end{tabular} & \begin{tabular}{|r|}
0.9 \\
19 \\
32 \\
45 \\
72 \\
9
\end{tabular} & $\begin{array}{r}0.92 \\
5093 \\
5303\end{array}$ \\
\hline & \begin{tabular}{r|}
0.0 \\
01 \\
56 \\
08 \\
99 \\
3
\end{tabular} & \begin{tabular}{|r|}
0.0 \\
00 \\
89 \\
16 \\
94 \\
5 \\
\end{tabular} & \begin{tabular}{|r|}
0.0 \\
00 \\
60 \\
65 \\
88 \\
1
\end{tabular} & \begin{tabular}{r||}
0.0 \\
01 \\
12 \\
85 \\
16 \\
7
\end{tabular} & $\left|\begin{array}{|c}0.0 \\
01 \\
32 \\
57 \\
97\end{array}\right|$ & \begin{tabular}{|r||}
0.0 \\
01 \\
31 \\
11 \\
05 \\
7
\end{tabular} & \begin{tabular}{||r||}
0.0 \\
01 \\
17 \\
36 \\
82 \\
4 \\
\end{tabular} & & $\begin{array}{r}0.0 \\
00 \\
18 \\
75 \\
58 \\
7\end{array}$ & \begin{tabular}{r|}
0.0 \\
01 \\
11 \\
90 \\
63 \\
2 \\
\end{tabular} & \begin{tabular}{|r|} 
\\
\\
0.00 \\
0753 \\
4089 \\
\end{tabular} & \begin{tabular}{|r|}
0.0 \\
01 \\
12 \\
31 \\
63 \\
5 \\
\end{tabular} & 0 & \begin{tabular}{|r|}
0.0 \\
00 \\
93 \\
22 \\
37 \\
2
\end{tabular} & \begin{tabular}{|r|}
0.0 \\
00 \\
55 \\
45 \\
51 \\
2 \\
\end{tabular} & 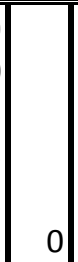 & \begin{tabular}{|r|}
0.0 \\
00 \\
51 \\
28 \\
51 \\
8
\end{tabular} & \begin{tabular}{|r|}
0.0 \\
00 \\
13 \\
96 \\
27 \\
1
\end{tabular} & \begin{tabular}{||c} 
\\
0.00 \\
0513 \\
0361
\end{tabular} & \begin{tabular}{|r|}
0.0 \\
00 \\
51 \\
38 \\
80 \\
7
\end{tabular} & \begin{tabular}{|r|}
0.0 \\
39 \\
74 \\
81 \\
57 \\
6 \\
\end{tabular} & \begin{tabular}{|r}
0.0 \\
00 \\
13 \\
93 \\
56 \\
5
\end{tabular} & \\
\hline & $\begin{array}{r}0.0 \\
01 \\
17 \\
26 \\
18 \\
7\end{array}$ & 0 & 0 & $\begin{array}{r}0.0 \\
00 \\
69 \\
94 \\
29 \\
4\end{array}$ & 0 & 0 & 0 & 0 & 0 & 0 & 0 & $\begin{array}{r}0.0 \\
01 \\
24 \\
72\end{array}$ & $\begin{array}{r}0.00 \\
0178 \\
189\end{array}$ & 0 & 0 & $\mid$\begin{tabular}{||r}
0.0 \\
00 \\
99 \\
21 \\
84 \\
6
\end{tabular} & 0 & | & \begin{tabular}{|r}
8.67 \\
1862 \\
2184 \\
7847 \\
E-
\end{tabular} & \begin{tabular}{|r|}
0.0 \\
00 \\
52 \\
11 \\
68 \\
3 \\
\end{tabular} & $\begin{array}{r}0.0 \\
00 \\
57 \\
60 \\
97 \\
3\end{array}$ & 0 & \\
\hline & $\begin{array}{r}4.1 \\
26 \\
94\end{array}$ & $\begin{array}{r}4.1 \\
23 \\
85\end{array}$ & \begin{tabular}{|r||}
4.1 \\
26 \\
53
\end{tabular} & $\begin{array}{r}4.1 \\
32 \\
81\end{array}$ & $\mid \begin{array}{r}4.1 \\
12 \\
90\end{array}$ & \begin{tabular}{|r||}
4.1 \\
28 \\
71
\end{tabular} & \begin{tabular}{||r||}
4.1 \\
22 \\
79 \\
$\mid$
\end{tabular} & $\mid$\begin{tabular}{|r|}
4.1 \\
08 \\
41
\end{tabular} & \begin{tabular}{|r|}
4.1 \\
12
\end{tabular} & \begin{tabular}{r||}
4.1 \\
00 \\
85
\end{tabular} & \begin{tabular}{|}
4.12 \\
4688 \\
2549
\end{tabular} & \begin{tabular}{|r|}
4.1 \\
11 \\
45
\end{tabular} & $\begin{array}{r}4.11 \\
6625 \\
2624\end{array}$ & \begin{tabular}{r||}
4.1 \\
35 \\
43
\end{tabular} & \begin{tabular}{|r||}
4.1 \\
15 \\
13
\end{tabular} & $\mid \begin{array}{r}4.1 \\
09 \\
68\end{array}$ & \begin{tabular}{|r|}
4.1 \\
03 \\
71
\end{tabular} & \begin{tabular}{|r||}
4.1 \\
15 \\
84
\end{tabular} & $\mid$\begin{tabular}{|}
4.11 \\
4260 \\
7152
\end{tabular} & $\mid \begin{array}{r}4.1 \\
49 \\
27\end{array}$ & $\mid \begin{array}{r}3.9 \\
19 \\
83\end{array}$ & $\begin{array}{l}13 \\
71\end{array}$ & $\begin{array}{c}4.12 \\
5754 \\
9262\end{array}$ \\
\hline
\end{tabular}

(C) 2017 American Geophysical Union. All rights reserved. 


\begin{tabular}{|r|r||r||r||r|r||r||r|r|r|r|r|r|r||r|r|r|r|r||r|r|r|r|}
\hline 47 & 77 & 11 & 64 & 23 & 13 & 62 & 59 & 50 & 03 & & 17 & & 96 & 10 & 18 & 69 & 90 & & 24 & 91 & 99 & \\
40 & 10 & 64 & 15 & 84 & 87 & 12 & 52 & 82 & 29 & & 63 & & 92 & 79 & 23 & 32 & 00 & & 55 & 52 & 97 & \\
\hline 3 & 2 & & 1 & 8 & 1 & 3 & & 5 & 5 & & 1 & & 5 & 9 & 3 & 5 & 1 & & 8 & 2 & 7 & \\
\hline
\end{tabular}

\begin{tabular}{|c|c|c|c|c|c|c|c|c|c|c|c|c|c|c|c|c|c|c|c|c|c|c|c|}
\hline & 24 & 25 & 26 & 27 & 28 & 29 & 30 & 31 & 32 & 33 & 34 & 35 & 36 & 37 & $\mid$\begin{tabular}{||c||} 
\\
$\mid$
\end{tabular} & 39 & 40 & 41 & 42 & 43 & 44 & 45 & 46 \\
\hline ol & $\begin{array}{r}56 . \\
13 \\
3 \\
\end{array}$ & $\begin{array}{r}56 . \\
61 \\
5 \\
\end{array}$ & \begin{tabular}{||r}
56. \\
25 \\
1
\end{tabular} & $\begin{array}{r}55 . \\
69 \\
4\end{array}$ & $\mid \begin{array}{r}56 . \\
03 \\
3\end{array}$ & $\begin{array}{r}56 \\
01 \\
9 \\
9\end{array}$ & $\mid$\begin{tabular}{|r|r}
54. \\
13 \\
1
\end{tabular} & $\begin{array}{r}55 \\
56 \\
5\end{array}$ & \begin{tabular}{|r}
56. \\
79 \\
1
\end{tabular} & \begin{tabular}{|r|}
56. \\
31 \\
7
\end{tabular} & $\begin{array}{r}56.1 \\
11 \\
\end{array}$ & $\begin{array}{c}56 . \\
08\end{array}$ & $\begin{array}{r}55.8 \\
36\end{array}$ & \begin{tabular}{|c||}
$56 . \mid$ \\
76
\end{tabular} & $\mid$\begin{tabular}{||r}
$57 . \mid$ \\
34 \\
8
\end{tabular} & $\mid \begin{array}{r}56 \\
08 \\
4\end{array}$ & \begin{tabular}{|r|}
55. \\
78 \\
6
\end{tabular} & \begin{tabular}{|r||}
53. \\
28 \\
8
\end{tabular} & $\begin{array}{r}56.5 \\
7\end{array}$ & \begin{tabular}{|r||}
54. \\
87 \\
7
\end{tabular} & $\begin{array}{r}55 . \\
88 \\
7\end{array}$ & $\begin{array}{r}55 . \\
79\end{array}$ & $\begin{array}{r}55.6 \\
33\end{array}$ \\
\hline 2 & $\begin{array}{r}0.0 \\
26\end{array}$ & $\begin{array}{r}0.0 \\
31 \\
\end{array}$ & $\begin{array}{r}0.0 \\
21 \\
\end{array}$ & $\begin{array}{r}0.0 \\
41\end{array}$ & $\left|\begin{array}{r}0.1 \\
14\end{array}\right|$ & $\begin{array}{r}0.0 \\
65 \\
\end{array}$ & \begin{tabular}{|r||}
0.0 \\
7
\end{tabular} & 0 & $\begin{array}{r}0.0 \\
1\end{array}$ & \begin{tabular}{|r|}
0.0 \\
23 \\
\end{tabular} & $\begin{array}{r}0.09 \\
6\end{array}$ & \begin{tabular}{|r|}
0.0 \\
52 \\
\end{tabular} & $\begin{array}{r}0.02 \\
1\end{array}$ & 0 & $\mid \begin{array}{r}0.0 \\
52\end{array}$ & $\begin{array}{r}0.0 \\
28\end{array}$ & \begin{tabular}{|r|}
0.0 \\
1
\end{tabular} & \begin{tabular}{|r||}
0.1 \\
16
\end{tabular} & $\begin{array}{r}0.06 \\
7\end{array}$ & $\mid$\begin{tabular}{r||}
0.0 \\
64
\end{tabular} & $\begin{array}{r}0.0 \\
28\end{array}$ & $\begin{array}{r}0.0 \\
7\end{array}$ & 0.07 \\
\hline 0 & $\begin{array}{r}13 . \\
62 \\
1 \\
\end{array}$ & $\begin{array}{r}15 . \\
06 \\
3\end{array}$ & $\mid \begin{array}{r}14 . \mid \\
07 \\
5\end{array}$ & \begin{tabular}{|r||}
14. \\
59 \\
9
\end{tabular} & $\mid \begin{array}{r}13 . \\
35 \\
9\end{array}$ & $\begin{array}{r}12 \\
23 \\
6\end{array}$ & \begin{tabular}{|r|r}
10. \\
90 \\
2
\end{tabular} & $\begin{array}{r}11 . \\
28 \\
8\end{array}$ & \begin{tabular}{|r|}
15. \\
01 \\
2
\end{tabular} & $\begin{array}{r}13 . \\
70 \\
6\end{array}$ & $\begin{array}{r}13.4 \\
79 \\
\end{array}$ & $\begin{array}{r}13 . \\
58\end{array}$ & $\begin{array}{r}12.1 \\
04\end{array}$ & \begin{tabular}{|r||}
$16 . \mid$ \\
74
\end{tabular} & \begin{tabular}{||r}
15. \\
22 \\
3
\end{tabular} & $\begin{array}{r}12 . \\
91 \\
6\end{array}$ & $\begin{array}{r}14 . \\
28 \\
9\end{array}$ & \begin{tabular}{|r||}
12. \\
23 \\
8
\end{tabular} & $\begin{array}{r}11.3 \\
07\end{array}$ & \begin{tabular}{|r|}
10. \\
72 \\
3 \\
\end{tabular} & $\begin{array}{r}13 . \\
54 \\
4\end{array}$ & $\begin{array}{r}13 . \\
86 \\
8\end{array}$ & $\begin{array}{r}12.6 \\
49\end{array}$ \\
\hline $\mathrm{F}$ & $\begin{array}{r}13 . \\
82\end{array}$ & \begin{tabular}{r|}
12. \\
89 \\
4
\end{tabular} & \begin{tabular}{||r||}
13. \\
27 \\
7
\end{tabular} & \begin{tabular}{|r|}
13. \\
55 \\
9 \\
\end{tabular} & \begin{tabular}{|r|}
13. \\
99 \\
9
\end{tabular} & $\begin{array}{r}14 . \\
66 \\
3\end{array}$ & \begin{tabular}{|r||} 
\\
16. \\
17
\end{tabular} & \begin{tabular}{|r|}
15. \\
25 \\
5 \\
\end{tabular} & \begin{tabular}{|r|}
12. \\
28 \\
5
\end{tabular} & $\begin{array}{r}13 . \\
80 \\
2\end{array}$ & $\begin{array}{r}13.9 \\
32\end{array}$ & \begin{tabular}{|r|}
13. \\
95 \\
6
\end{tabular} & $\begin{array}{r}14.5 \\
5\end{array}$ & \begin{tabular}{|r||}
$11 . \mid$ \\
04 \\
5
\end{tabular} & \begin{tabular}{||r||}
11. \\
39 \\
1
\end{tabular} & $\begin{array}{r}13 . \\
78 \\
2\end{array}$ & \begin{tabular}{|r|}
12. \\
80 \\
4 \\
\end{tabular} & \begin{tabular}{|r|}
15 \\
42 \\
9 \\
\end{tabular} & \begin{tabular}{r|}
15.3 \\
03
\end{tabular} & \begin{tabular}{|r|}
15. \\
87 \\
7
\end{tabular} & \begin{tabular}{|r|}
13. \\
62 \\
1
\end{tabular} & \begin{tabular}{|r|}
13. \\
19 \\
1
\end{tabular} & $\begin{array}{r}14.5 \\
07\end{array}$ \\
\hline 0 & $\begin{array}{r}0.1 \\
56\end{array}$ & $\begin{array}{r}0.1 \\
01 \\
\end{array}$ & \begin{tabular}{|r|}
0.0 \\
81 \\
\end{tabular} & $\begin{array}{r}0.1 \\
16\end{array}$ & \begin{tabular}{|r}
0.0 \\
45 \\
\end{tabular} & $\begin{array}{r}0.0 \\
35 \\
\end{array}$ & \begin{tabular}{|c||}
0.1 \\
26 \\
\end{tabular} & $\begin{array}{r}0.0 \\
75 \\
\end{array}$ & \begin{tabular}{|r|}
0.1 \\
06
\end{tabular} & \begin{tabular}{|c|}
0.0 \\
76
\end{tabular} & $\begin{array}{r}0.15 \\
1\end{array}$ & $\begin{array}{r}0.0 \\
35\end{array}$ & 0 & 0 & $\begin{array}{r}0.0 \\
4\end{array}$ & $\begin{array}{r}0.0 \\
2\end{array}$ & 0 & \begin{tabular}{|r||}
0.2 \\
31
\end{tabular} & $\begin{array}{r}0.10 \\
6\end{array}$ & $\mid$\begin{tabular}{r||}
0.0 \\
86
\end{tabular} & $\begin{array}{r}0.0 \\
86\end{array}$ & $\begin{array}{r}0.0 \\
96\end{array}$ & $\begin{array}{r}0.04 \\
5\end{array}$ \\
\hline 0 & $\begin{array}{r}1.0 \\
39 \\
\end{array}$ & $\begin{array}{r}0.8 \\
33\end{array}$ & $\mid$\begin{tabular}{|c|c|}
0.8 \\
98
\end{tabular} & \begin{tabular}{|r||}
1.1 \\
08 \\
\end{tabular} & \begin{tabular}{|r|}
1.0 \\
97
\end{tabular} & \begin{tabular}{|r|}
1.3 \\
77
\end{tabular} & \begin{tabular}{||c||}
1.8 \\
04
\end{tabular} & $\begin{array}{r}1.6 \\
36\end{array}$ & \begin{tabular}{|r|}
0.7 \\
79
\end{tabular} \mid & $\begin{array}{r}0.8 \\
69\end{array}$ & $\begin{array}{r}1.08 \\
5\end{array}$ & \begin{tabular}{|r|}
1.0 \\
54
\end{tabular} \mid & $\begin{array}{r}1.32 \\
8 \\
\end{array}$ & \begin{tabular}{|c||}
0.5 \\
04
\end{tabular} \mid & \begin{tabular}{|r||}
0.8 \\
14
\end{tabular} & $\begin{array}{r}0.9 \\
98 \\
-1\end{array}$ & $\begin{array}{r}0.8 \\
81\end{array}$ & \begin{tabular}{|r||}
1.7 \\
28
\end{tabular} & $\begin{array}{r}1.62 \\
9\end{array}$ & \begin{tabular}{|r||}
1.6 \\
82
\end{tabular} & $\begin{array}{r}1.0 \\
79\end{array}$ & $\begin{array}{r}1.0 \\
14\end{array}$ & $\begin{array}{r}1.09 \\
2\end{array}$ \\
\hline $\mathrm{O}$ & $\begin{array}{l}2.4 \\
09\end{array}$ & $\begin{array}{r}1.9 \\
14\end{array}$ & \begin{tabular}{||r||}
2.2 \\
55
\end{tabular} & \begin{tabular}{|r||}
2.7 \\
64
\end{tabular} & $\mid$\begin{tabular}{||r|}
2.7 \\
47
\end{tabular} & \begin{tabular}{|r||}
3.4 \\
26
\end{tabular} & \begin{tabular}{|r|r}
4.4 \\
48
\end{tabular} & \begin{tabular}{|r|}
3.7 \\
4
\end{tabular} & \begin{tabular}{|r|}
1.6 \\
21
\end{tabular} & $\begin{array}{r}2.2 \\
03\end{array}$ & $\begin{array}{r}2.70 \\
7\end{array}$ & \begin{tabular}{|r|}
2.4 \\
19
\end{tabular} & $\begin{array}{r}3.17 \\
6\end{array}$ & \begin{tabular}{|c|}
1.2 \\
36
\end{tabular} & \begin{tabular}{||c|}
1.6 \\
56
\end{tabular} & $\mid \begin{array}{r}2.2 \\
59\end{array}$ & \begin{tabular}{|r|}
2.3 \\
09
\end{tabular} & \begin{tabular}{|r||}
6.0 \\
17
\end{tabular} & $\begin{array}{r}3.74 \\
4\end{array}$ & $\mid$\begin{tabular}{|r||}
4.1 \\
27
\end{tabular} & $\begin{array}{r}2.4 \\
85\end{array}$ & $\begin{array}{r}2.5 \\
89\end{array}$ & $\begin{array}{r}2.57 \\
5\end{array}$ \\
\hline 0 & $\begin{array}{r}13 . \\
22 \\
\end{array}$ & $\begin{array}{r}13 . \\
21 \\
9 \\
\end{array}$ & \begin{tabular}{||r}
12. \\
83 \\
7
\end{tabular} & $\begin{array}{c}12 . \\
72 \\
72\end{array}$ & \begin{tabular}{|r|}
12. \\
58 \\
5
\end{tabular} & \begin{tabular}{|r||}
12. \\
11 \\
5
\end{tabular} & \begin{tabular}{|r|r}
$11 . \mid$ \\
06 \\
2
\end{tabular} & $\begin{array}{r}12 . \\
04 \\
3 \\
\end{array}$ & \begin{tabular}{|r|}
13. \\
46 \\
1
\end{tabular} & $\begin{array}{r}12 . \\
90 \\
8\end{array}$ & $\begin{array}{r}13.0 \\
3 \\
\end{array}$ & \begin{tabular}{|r|}
12. \\
89 \\
8 \\
\end{tabular} & $\begin{array}{r}12.4 \\
2 \\
\end{array}$ & \begin{tabular}{|r||}
13. \\
98 \\
2
\end{tabular} & \begin{tabular}{||r|r}
13. \\
22 \\
8
\end{tabular} & $\begin{array}{r}12 . \\
57 \\
2\end{array}$ & \begin{tabular}{|r|}
12. \\
72 \\
9 \\
\end{tabular} & \begin{tabular}{|r||}
10. \\
29 \\
5
\end{tabular} & $\begin{array}{r}12.0 \\
62\end{array}$ & \begin{tabular}{|r||}
11. \\
79 \\
9
\end{tabular} & $\begin{array}{r}12 . \\
82 \\
1\end{array}$ & $\begin{array}{r}12 . \\
53 \\
5\end{array}$ & $\begin{array}{r}12.3 \\
28\end{array}$ \\
\hline O & $\begin{array}{r}0.0 \\
09 \\
\end{array}$ & \begin{tabular}{r||}
0.0 \\
1 \\
\end{tabular} & \begin{tabular}{|r||}
0.0 \\
13 \\
\end{tabular} & $\begin{array}{r}0.0 \\
5\end{array}$ & 0 & \begin{tabular}{|r|}
0.0 \\
03 \\
\end{tabular} & $\mid \begin{array}{r}0.0 \\
18\end{array}$ & $\begin{array}{r}0.0 \\
09\end{array}$ & $\left|\begin{array}{r}0.0 \\
03\end{array}\right|$ & $\begin{array}{r}0.0 \\
16\end{array}$ & 0 & 0 & $\begin{array}{r}0.00 \\
2\end{array}$ & \begin{tabular}{|c|}
0.0 \\
24
\end{tabular} \mid & \begin{tabular}{||c||}
0.0 \\
12
\end{tabular} & $\begin{array}{r}0.0 \\
05\end{array}$ & $\begin{array}{r}0.0 \\
18\end{array}$ & \begin{tabular}{|c|}
0.0 \\
05
\end{tabular} \mid & 0.01 & $\mid$\begin{tabular}{r||}
0.0 \\
05
\end{tabular} & $\begin{array}{r}0.0 \\
1\end{array}$ & $\begin{array}{r}0.0 \\
18\end{array}$ & 0.02 \\
\hline & $\begin{array}{r}0.0 \\
1 \\
\end{array}$ & 0 & $\begin{array}{r}0.0 \\
4\end{array}$ & $\begin{array}{r}0.0 \\
24\end{array}$ & $\begin{array}{r}0.0 \\
32\end{array}$ & 0 & 0 & $\begin{array}{r}0.0 \\
21\end{array}$ & \begin{tabular}{|r|}
0.0 \\
16
\end{tabular} & \begin{tabular}{|c|}
0.0 \\
03
\end{tabular} & $\begin{array}{r}0.00 \\
3\end{array}$ & 0 & 0 & 0 & 0 & $\mid \begin{array}{r}0.0 \\
1\end{array}$ & \begin{tabular}{r|r}
0.0 \\
31
\end{tabular} & \begin{tabular}{|r||}
0.0 \\
22
\end{tabular} & $\begin{array}{r}0.01 \\
3\end{array}$ & $\begin{array}{r}0.0 \\
06\end{array} \mid$ & 0 & 이 & $\begin{array}{r}0.00 \\
2\end{array}$ \\
\hline & $\begin{array}{r}10 \\
0.4 \\
43\end{array}$ & $\begin{array}{r}10 \\
0.6 \\
8\end{array}$ & $\mid \begin{array}{r}99 . \\
74 \\
8\end{array}$ & \begin{tabular}{|r||}
10 \\
0.6 \\
75
\end{tabular} & $\mid \begin{array}{r}10 \\
0.0 \\
11\end{array}$ & \begin{tabular}{|r||}
99. \\
93 \\
9
\end{tabular} & $\mid$\begin{tabular}{|r}
98. \\
73 \\
1
\end{tabular} & $\begin{array}{r}99 . \\
63 \\
2\end{array}$ & \begin{tabular}{|r|}
10 \\
0.0 \\
84
\end{tabular} & \begin{tabular}{|r|}
99. \\
92 \\
3
\end{tabular} & $\begin{array}{r}100 . \\
594\end{array}$ & \begin{tabular}{|r|}
10 \\
0.0 \\
8
\end{tabular} & $\begin{array}{r}99.4 \\
37\end{array}$ & \begin{tabular}{|r||}
10 \\
0.2 \\
91
\end{tabular} & $\mid$\begin{tabular}{|r}
99. \\
76 \\
4
\end{tabular} & $\begin{array}{r}98 . \\
67 \\
4\end{array}$ & $\begin{array}{r}98 . \\
85 \\
7\end{array}$ & \begin{tabular}{|r|}
99. \\
36 \\
9
\end{tabular} & $\begin{array}{r}100 . \\
811\end{array}$ & $\begin{array}{r}99 . \\
24 \\
6\end{array}$ & $\begin{array}{r}99 . \\
56 \\
1\end{array}$ & $\begin{array}{r}99 . \\
17 \\
1\end{array}$ & $\begin{array}{r}98.9 \\
21\end{array}$ \\
\hline
\end{tabular}

\begin{tabular}{|r|r|r|r||r||r|r||r||r|r|r||r|r|r|r|r||r|r|r|r||r|r|r|r|}
\hline & 2.0 & 2.0 & & 2.0 & 2.0 & 2.0 & 2.0 & 2.0 & 2.0 & 2.0 & & 2.0 & & 2.0 & 2.0 & 2.0 & 2.0 & 1.9 & & 2.0 & 2.0 & 2.0 & \\
& 40 & 35 & 2.0 & 16 & 44 & 55 & 36 & 57 & 46 & 51 & & 43 & & 27 & 59 & 68 & 44 & 91 & & 51 & 45 & 44 & \\
& 73 & 42 & 47 & 67 & 80 & 38 & 79 & 23 & 90 & 76 & & 93 & & 17 & 59 & 28 & 30 & 88 & & 04 & 51 & 04 & \\
& 10 & 93 & 43 & 08 & 00 & 21 & 95 & 82 & 90 & 36 & 2.03 & 37 & 2.05 & 60 & 41 & 65 & 00 & 07 & 2.06 & 11 & 74 & 50 & 2.05 \\
$\mathrm{~S}$ & 07 & 86 & 54 & 40 & 17 & 17 & 36 & 56 & 12 & 44 & 8828 & 12 & 9189 & 15 & 36 & 91 & 02 & 48 & 6216 & 65 & 26 & 51 & 7234 \\
$\mathrm{i}$ & 7 & 6 & 54 & 7 & 3 & 4 & 6 & 9 & 8 & 4 & 9316 & 1 & 1476 & 8 & 9 & 7 & 1 & 9 & 9132 & 6 & 3 & 1 & 5303 \\
\hline $\mathrm{T}$ & 0.0 & 0.0 & 0.0 & 0.0 & 0.0 & 0.0 & 0.0 & 0 & 0.0 & 0.0 & 0.00 & 0.0 & 0.00 & 0 & 0.0 & 0.0 & 0.0 & 0.0 & 0.00 & 0.0 & 0.0 & 0.0 & 0.00 \\
\hline
\end{tabular}




\begin{tabular}{|c|c|c|c|c|c|c|c|c|c|c|c|c|c|c|c|c|c|c|c|c|c|c|c|}
\hline \multicolumn{2}{|r|}{$\begin{array}{l}0 \\
7 \\
0 \\
6\end{array}$} & \begin{tabular}{|r|}
00 \\
83 \\
80 \\
48 \\
9
\end{tabular} \mid & $\mid \begin{array}{r}00 \\
57 \\
47 \\
54 \\
5\end{array}$ & $\begin{array}{r}01 \\
11 \\
63 \\
32 \\
6 \\
6\end{array}$ & $\begin{array}{r}03 \\
12 \\
82 \\
03 \\
2\end{array}$ & $\begin{array}{r}01 \\
79 \\
33 \\
03 \\
2 \\
\end{array}$ & \begin{tabular}{|r|r||}
01 \\
98 \\
05 \\
39 \\
1 \\
\end{tabular} & & $\begin{array}{r}00 \\
27 \\
10 \\
20 \\
5 \\
\end{array}$ & \begin{tabular}{|r|}
00 \\
63 \\
00 \\
84 \\
5 \\
\end{tabular} & $\mid$\begin{tabular}{||c}
2622 \\
9328 \\
\end{tabular} & $\begin{array}{r}01 \\
42 \\
50 \\
99 \\
8\end{array}$ & $\begin{array}{l}0582 \\
3504\end{array}$ & & $\begin{array}{r}01 \\
40 \\
42 \\
67 \\
5 \\
\end{array}$ & \begin{tabular}{||l|}
00 \\
77 \\
64 \\
49 \\
\end{tabular} & $\begin{array}{r}00 \\
27 \\
55 \\
51 \\
4 \\
\end{array}$ & \begin{tabular}{r||}
03 \\
26 \\
04 \\
31 \\
3 \\
3
\end{tabular} & \begin{tabular}{|l|}
1840 \\
1265 \\
\\
\\
\end{tabular} & $\mid$\begin{tabular}{||l||}
01 \\
79 \\
86 \\
52
\end{tabular} & $\begin{array}{r}00 \\
77 \\
06 \\
08 \\
1 \\
\end{array}$ & \multicolumn{2}{|c|}{\begin{tabular}{l|l}
1 & 194 \\
2 & 401 \\
4 & \\
0 & \\
7 &
\end{tabular}} \\
\hline$A$ & $\begin{array}{r}0.5 \\
83 \\
70 \\
28 \\
22 \\
3\end{array}$ & \begin{tabular}{|c||}
0.6 \\
38 \\
33 \\
88 \\
77 \\
\end{tabular} & \begin{tabular}{||r||}
0.6 \\
03 \\
87 \\
02 \\
93 \\
7 \\
\end{tabular} & \begin{tabular}{||r||}
0.6 \\
23 \\
11 \\
04 \\
10 \\
7 \\
\end{tabular} & \begin{tabular}{||r}
0.5 \\
74 \\
64 \\
04 \\
65 \\
5 \\
\end{tabular} & \begin{tabular}{|r|}
0.5 \\
29 \\
19 \\
04 \\
28 \\
5 \\
\end{tabular} & \begin{tabular}{||r||}
0.4 \\
83 \\
53 \\
03 \\
12 \\
8 \\
\end{tabular} & \begin{tabular}{||r|}
0.4 \\
92 \\
62 \\
39 \\
97 \\
9 \\
\end{tabular} & \begin{tabular}{|r|}
0.6 \\
37 \\
78 \\
28 \\
96 \\
3 \\
\end{tabular} & \begin{tabular}{|r|}
0.5 \\
88 \\
59 \\
12 \\
96 \\
9 \\
\end{tabular} & \begin{tabular}{||c|} 
\\
\\
0.57 \\
7305 \\
5634 \\
\end{tabular} & \begin{tabular}{|r|}
0.5 \\
83 \\
66 \\
77 \\
56 \\
9 \\
\end{tabular} & \begin{tabular}{|}
$\mid$ \\
0.52 \\
6170 \\
0785 \\
\end{tabular} & $\begin{array}{r}0.7 \\
04 \\
72 \\
52 \\
24 \\
\mid\end{array}$ & \begin{tabular}{|r|}
0.6 \\
44 \\
43 \\
46 \\
86 \\
4 \\
\end{tabular} & \begin{tabular}{||r|}
0.5 \\
61 \\
45 \\
51 \\
40 \\
7 \\
\end{tabular} & \begin{tabular}{|r|}
0.6 \\
17 \\
21 \\
50 \\
86 \\
9 \\
\end{tabular} & \begin{tabular}{r||}
0.5 \\
39 \\
21 \\
21 \\
29 \\
3 \\
3
\end{tabular} & \begin{tabular}{||c||} 
\\
\\
0.48 \\
6802 \\
0697 \\
\end{tabular} & \begin{tabular}{|r|}
0.4 \\
72 \\
40 \\
62 \\
25 \\
2 \\
\end{tabular} & \begin{tabular}{|r|}
0.5 \\
84 \\
32 \\
52 \\
07 \\
3 \\
\end{tabular} & \begin{tabular}{r|r}
0.5 & \\
98 & \\
91 & \\
22 & \\
90 & 1 \\
5 & 1 \\
\end{tabular} & $\begin{array}{r} \\
0.55 \\
1344 \\
1976 \\
\end{array}$ \\
\hline$F$ & $\begin{array}{r}0.4 \\
20 \\
12 \\
51 \\
73 \\
1\end{array}$ & \begin{tabular}{|r|}
0.3 \\
87 \\
62 \\
81 \\
83 \\
6 \\
\end{tabular} & \begin{tabular}{||r||}
0.4 \\
04 \\
09 \\
46 \\
29 \\
5 \\
\end{tabular} & \begin{tabular}{||c||}
0.4 \\
10 \\
54 \\
18 \\
36 \\
4
\end{tabular} & \begin{tabular}{||r|}
0.4 \\
27 \\
17 \\
62 \\
80 \\
6 \\
\end{tabular} & \begin{tabular}{|r|}
0.4 \\
49 \\
86 \\
60 \\
37 \\
9
\end{tabular} & \begin{tabular}{||c||}
0.5 \\
08 \\
76 \\
28 \\
70
\end{tabular} & \begin{tabular}{||c|} 
\\
0.4 \\
72 \\
27 \\
90 \\
02 \\
\end{tabular} & \begin{tabular}{|r|}
0.3 \\
70 \\
25 \\
19 \\
33 \\
1 \\
\end{tabular} & \begin{tabular}{|r|}
0.4 \\
20 \\
46 \\
80 \\
42 \\
4 \\
\end{tabular} & $\mid \begin{array}{c} \\
\\
0.42 \\
3301 \\
0993\end{array}$ & \begin{tabular}{|r|}
0.4 \\
25 \\
32 \\
69 \\
62 \\
1 \\
\end{tabular} & \begin{tabular}{|r|} 
\\
\\
0.44 \\
8691 \\
7528 \\
\end{tabular} & $\begin{array}{r}0.3 \\
29 \\
85 \\
11 \\
05 \\
7 \\
\end{array}$ & \begin{tabular}{|r|}
0.3 \\
42 \\
08 \\
05 \\
43 \\
6 \\
\end{tabular} & \begin{tabular}{||r|}
0.4 \\
24 \\
99 \\
82 \\
41 \\
4 \\
\end{tabular} & \begin{tabular}{|r|}
0.3 \\
92 \\
34 \\
50 \\
91 \\
4
\end{tabular} & \begin{tabular}{|r||}
0.4 \\
82 \\
25 \\
28 \\
95 \\
8 \\
8
\end{tabular} & \begin{tabular}{|l||} 
\\
\\
0.46 \\
7379 \\
2886 \\
\end{tabular} & \begin{tabular}{r||}
0.4 \\
96 \\
19 \\
86 \\
88 \\
3 \\
\end{tabular} & \begin{tabular}{|r|}
0.4 \\
16 \\
87 \\
37 \\
32 \\
5 \\
\end{tabular} & \begin{tabular}{r|r}
0.4 & \\
04 & \\
12 & \\
43 & 8 \\
08 & 9 \\
\end{tabular} & $\begin{array}{r}0.44 \\
8571 \\
9243 \\
\end{array}$ \\
\hline & \begin{tabular}{|r|} 
\\
0.0 \\
04 \\
80 \\
32 \\
02 \\
\end{tabular} & \begin{tabular}{|r|}
0.0 \\
03 \\
07 \\
52 \\
79 \\
8 \\
\end{tabular} & \begin{tabular}{|r|}
0.0 \\
02 \\
49 \\
69 \\
14 \\
8 \\
\end{tabular} & \begin{tabular}{||r||}
0.0 \\
03 \\
55 \\
73 \\
23 \\
3 \\
\end{tabular} & \begin{tabular}{||r|}
0.0 \\
01 \\
39 \\
07 \\
79 \\
3 \\
\end{tabular} & \begin{tabular}{|r||}
0.0 \\
01 \\
08 \\
75 \\
87 \\
\end{tabular} & \begin{tabular}{|r|}
0.0 \\
04 \\
01 \\
52 \\
40 \\
1 \\
\end{tabular} & \begin{tabular}{|r|}
0.0 \\
02 \\
35 \\
17 \\
07 \\
\end{tabular} & \begin{tabular}{|r|}
0.0 \\
03 \\
23 \\
56 \\
65 \\
6 \\
\end{tabular} & \begin{tabular}{|r|}
0.0 \\
02 \\
34 \\
49 \\
85 \\
4 \\
\end{tabular} & \begin{tabular}{|r|} 
\\
\\
0.00 \\
4646 \\
741 \\
\end{tabular} & \begin{tabular}{|r|}
0.0 \\
01 \\
08 \\
03 \\
52 \\
8 \\
\end{tabular} & 0 & 0 & \begin{tabular}{|r|}
0.0 \\
01 \\
21 \\
66 \\
4 \\
\end{tabular} & \begin{tabular}{|r|}
0.0 \\
00 \\
62 \\
46 \\
55 \\
4 \\
\end{tabular} & 이 & \begin{tabular}{|r||}
0.0 \\
07 \\
31 \\
28 \\
15 \\
8 \\
\end{tabular} & \begin{tabular}{|c||} 
\\
0.00 \\
3278 \\
9466 \\
\end{tabular} & \begin{tabular}{r||}
0.0 \\
02 \\
72 \\
22 \\
07 \\
4 \\
\end{tabular} & \begin{tabular}{|r|}
0.0 \\
02 \\
66 \\
58 \\
12 \\
4 \\
\end{tabular} & \begin{tabular}{r|}
0.0 \\
02 \\
97 \\
88 \\
18 \\
7 \\
\end{tabular} & $\begin{array}{r} \\
0.00 \\
1409 \\
2972 \\
\end{array}$ \\
\hline & $\begin{array}{r}0.0 \\
56 \\
29 \\
89 \\
35 \\
5\end{array}$ & \begin{tabular}{|r|}
0.0 \\
44 \\
63 \\
61 \\
42 \\
6 \\
\end{tabular} & \begin{tabular}{|r|}
0.0 \\
48 \\
71 \\
62 \\
03 \\
3 \\
\end{tabular} & \begin{tabular}{||r||}
0.0 \\
59 \\
79 \\
75 \\
64 \\
3 \\
\end{tabular} & \begin{tabular}{||r|}
0.0 \\
59 \\
66 \\
65 \\
21 \\
3 \\
\end{tabular} & \begin{tabular}{|r|}
0.0 \\
75 \\
30 \\
23 \\
08 \\
\end{tabular} & \begin{tabular}{||l||}
0.1 \\
01 \\
17 \\
09 \\
65 \\
\end{tabular} & \begin{tabular}{|r|}
0.0 \\
90 \\
27 \\
83 \\
67 \\
\end{tabular} & \begin{tabular}{|r|}
0.0 \\
41 \\
84 \\
78 \\
93 \\
9 \\
\end{tabular} & \begin{tabular}{|r|}
0.0 \\
47 \\
18 \\
72 \\
55 \\
7 \\
\end{tabular} & \begin{tabular}{||c|} 
\\
\\
0.05 \\
8759 \\
7099 \\
\end{tabular} & \begin{tabular}{|r|}
0.0 \\
57 \\
25 \\
54 \\
11 \\
3 \\
\end{tabular} & \begin{tabular}{|r|} 
\\
\\
0.07 \\
2995 \\
6774 \\
\end{tabular} & $\begin{array}{l}82 \\
85 \\
21\end{array}$ & \begin{tabular}{|r|}
0.0 \\
43 \\
57 \\
17 \\
39 \\
8 \\
\end{tabular} & \begin{tabular}{|r|}
0.0 \\
54 \\
85 \\
54 \\
02 \\
1 \\
\end{tabular} & \begin{tabular}{|r|}
0.0 \\
48 \\
11 \\
85 \\
39 \\
9 \\
\end{tabular} & \begin{tabular}{|r||}
0.0 \\
96 \\
27 \\
08 \\
43 \\
6 \\
\end{tabular} & \begin{tabular}{||c||} 
\\
\\
0.08 \\
8680 \\
4613 \\
\end{tabular} & \begin{tabular}{|r||}
0.0 \\
93 \\
69 \\
73 \\
12 \\
2 \\
\end{tabular} & \begin{tabular}{|r|}
0.0 \\
58 \\
86 \\
14 \\
50 \\
1 \\
\end{tabular} & $\begin{array}{r}0.0 \\
55 \\
37 \\
18 \\
69\end{array}$ & $\begin{array}{l}0.06 \\
0185 \\
3915 \\
\end{array}$ \\
\hline & \begin{tabular}{|l|}
0.0 \\
93 \\
82 \\
66 \\
54 \\
\end{tabular} & \begin{tabular}{|r|}
0.0 \\
73 \\
72 \\
05 \\
18 \\
5 \\
\end{tabular} & $\mid$\begin{tabular}{||r||}
0.0 \\
87 \\
93 \\
23 \\
00 \\
9 \\
\end{tabular} & \begin{tabular}{|l||}
0.1 \\
07 \\
22 \\
26 \\
57
\end{tabular} & \begin{tabular}{||r|}
0.1 \\
07 \\
39 \\
58 \\
60 \\
8 \\
\end{tabular} & \begin{tabular}{|r|}
0.1 \\
34 \\
66 \\
86 \\
47 \\
8
\end{tabular} & \begin{tabular}{|r}
0.1 \\
79 \\
30 \\
35 \\
69 \\
3 \\
\end{tabular} & $\left|\begin{array}{|c}0.1 \\
48 \\
34 \\
63 \\
25\end{array}\right|$ & \begin{tabular}{|l|} 
\\
0.0 \\
62 \\
59 \\
27 \\
39 \\
\end{tabular} & \begin{tabular}{|r||}
0.0 \\
85 \\
98 \\
53 \\
04 \\
7
\end{tabular} & $\mid \begin{array}{r} \\
\\
0.10 \\
5376 \\
302 \\
\end{array}$ & \begin{tabular}{|r|}
0.0 \\
94 \\
45 \\
31 \\
81 \\
1
\end{tabular} & $\begin{array}{r}0.12 \\
5482 \\
8445\end{array}$ & 0.0 & $\begin{array}{r}0.0 \\
63 \\
71 \\
55 \\
77 \\
2\end{array}$ & $\mid \begin{array}{r}0.0 \\
89 \\
25 \\
03 \\
41 \\
4 \\
\end{array}$ & $\begin{array}{r}0.0 \\
90 \\
64 \\
94 \\
67 \\
8\end{array}$ & \begin{tabular}{r|}
0.2 \\
40 \\
95 \\
49 \\
45 \\
3
\end{tabular} & \begin{tabular}{|r||}
0.14 \\
6503 \\
3287 \\
\end{tabular} & $\begin{array}{r}0.1 \\
65 \\
24 \\
95 \\
94 \\
9 \\
\end{array}$ & $\mid \begin{array}{r}0.0 \\
97 \\
44 \\
07\end{array}$ & \begin{tabular}{r|}
0.1 \\
01 \\
62 \\
20 \\
78 \\
1
\end{tabular} & $\begin{array}{r}0.10 \\
2011 \\
8158 \\
\end{array}$ \\
\hline $\mathrm{N}$ & $\begin{array}{r}0.9 \\
31 \\
73 \\
69 \\
07 \\
7\end{array}$ & \begin{tabular}{|r|}
0.9 \\
21 \\
33 \\
47 \\
78 \\
6 \\
\end{tabular} & \begin{tabular}{|r|}
0.9 \\
05 \\
81 \\
15 \\
35 \\
3 \\
\end{tabular} & \begin{tabular}{||r|}
0.8 \\
92 \\
91 \\
07 \\
54 \\
2 \\
\end{tabular} & \begin{tabular}{||r|}
0.8 \\
90 \\
33 \\
71 \\
98 \\
8 \\
\end{tabular} & \begin{tabular}{|r||}
0.8 \\
61 \\
73 \\
74 \\
63 \\
8
\end{tabular} & $\mid \begin{array}{r}0.8 \\
06 \\
91 \\
95 \\
27 \\
3 \\
\end{array}$ & \begin{tabular}{|r|}
0.8 \\
64 \\
39 \\
50 \\
94 \\
\end{tabular} & \begin{tabular}{|r|}
0.9 \\
40 \\
56 \\
90 \\
42 \\
6 \\
\end{tabular} & \begin{tabular}{|r||} 
\\
0.9 \\
11 \\
67 \\
72 \\
32 \\
\end{tabular} & $\mid$\begin{tabular}{|c|} 
\\
\\
0.91 \\
7849 \\
6121
\end{tabular} & \begin{tabular}{r|}
0.9 \\
11 \\
32 \\
96 \\
67
\end{tabular} & $\begin{array}{r}0.88 \\
7969\end{array}$ & $\begin{array}{l}0.9 \\
68 \\
08 \\
32 \\
46\end{array}$ & \begin{tabular}{|r|}
0.9 \\
20 \\
98 \\
35 \\
86 \\
7 \\
\end{tabular} & $\mid \begin{array}{r}0.8 \\
98 \\
81 \\
52 \\
70 \\
3 \\
\end{array}$ & \begin{tabular}{|r|}
0.9 \\
04 \\
29 \\
06 \\
22 \\
1
\end{tabular} & \begin{tabular}{|r|}
0.7 \\
46 \\
02 \\
70 \\
90 \\
9 \\
\end{tabular} & \begin{tabular}{|r||} 
\\
\\
0.85 \\
4089 \\
5172 \\
5
\end{tabular} & $\begin{array}{r}0.8 \\
54 \\
91 \\
62 \\
07 \\
7\end{array}$ & \begin{tabular}{|r|}
0.9 \\
09 \\
72 \\
18 \\
38 \\
7
\end{tabular} & \begin{tabular}{r|}
0.8 \\
90 \\
33 \\
36 \\
22 \\
5
\end{tabular} & $\begin{array}{r}0.88 \\
3768 \\
026\end{array}$ \\
\hline KI & $\begin{array}{r}0.0 \\
00 \\
41 \\
73 \\
67 \\
9\end{array}$ & \begin{tabular}{|r|}
0.0 \\
00 \\
45 \\
85 \\
99 \\
5 \\
\end{tabular} & \begin{tabular}{||c||}
0.0 \\
00 \\
60 \\
35 \\
76 \\
5 \\
\end{tabular} & $\mid$\begin{tabular}{||c||}
0.0 \\
02 \\
30 \\
94 \\
34 \\
4
\end{tabular} & 0 & \begin{tabular}{r||}
0.0 \\
00 \\
14 \\
04 \\
06 \\
6 \\
\end{tabular} & \begin{tabular}{|r|}
0.0 \\
00 \\
86 \\
39 \\
40 \\
4 \\
\end{tabular} & \begin{tabular}{|r|}
0.0 \\
00 \\
42 \\
50 \\
44 \\
9 \\
\end{tabular} & \begin{tabular}{|c|} 
\\
0.0 \\
00 \\
13 \\
79 \\
27 \\
\end{tabular} & \begin{tabular}{|r|}
0.0 \\
00 \\
74 \\
35 \\
61 \\
4 \\
\end{tabular} & 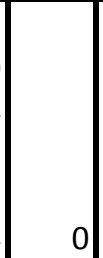 & 이 & $\begin{array}{r}9.40 \\
8512 \\
2495 \\
3297 \\
\mathrm{E}- \\
005\end{array}$ & \begin{tabular}{|r||}
0.0 \\
01 \\
09 \\
33 \\
75 \\
\end{tabular} & \begin{tabular}{|r||}
0.0 \\
00 \\
54 \\
97 \\
35 \\
3 \\
\end{tabular} & \begin{tabular}{|r|}
0.0 \\
00 \\
23 \\
52 \\
07 \\
3 \\
\end{tabular} & \begin{tabular}{|r|}
0.0 \\
00 \\
84 \\
13 \\
96 \\
9
\end{tabular} & \begin{tabular}{r|}
0.0 \\
00 \\
23 \\
84 \\
03 \\
7
\end{tabular} & \begin{tabular}{|r||} 
\\
\\
0.00 \\
0465 \\
9065 \\
\end{tabular} & \begin{tabular}{||r|||}
0.0 \\
00 \\
23 \\
83 \\
76 \\
3 \\
\end{tabular} & \begin{tabular}{|r|}
0.0 \\
00 \\
46 \\
68 \\
75 \\
8
\end{tabular} & \begin{tabular}{r|}
0.0 \\
00 \\
84 \\
12 \\
31 \\
7
\end{tabular} & $\begin{array}{r}0.00 \\
0943 \\
388\end{array}$ \\
\hline & $\begin{array}{l}0.0 \\
00 \\
28 \\
74 \\
17\end{array}$ & 0 & \begin{tabular}{|r|}
0.0 \\
01 \\
15 \\
10 \\
25 \\
3 \\
\end{tabular} & \begin{tabular}{||r||}
0.0 \\
00 \\
68 \\
70 \\
41 \\
2 \\
\end{tabular} & \begin{tabular}{||r|}
0.0 \\
00 \\
92 \\
32 \\
12 \\
9 \\
\end{tabular} & 0 & 0 & \begin{tabular}{r|}
0.0 \\
00 \\
61 \\
46 \\
77 \\
7
\end{tabular} & \begin{tabular}{|l|} 
\\
0.0 \\
00 \\
45 \\
59 \\
15 \\
\end{tabular} & \begin{tabular}{|c|}
0.0 \\
00 \\
08 \\
64 \\
08 \\
\end{tabular} & \begin{tabular}{||r|}
8.61 \\
7850 \\
1552 \\
2377 \\
$\mathrm{E}-$ \\
005 \\
\end{tabular} & & & & 0 & \begin{tabular}{|r|}
0.0 \\
00 \\
29 \\
15 \\
52 \\
4 \\
\end{tabular} & \begin{tabular}{|r|}
0.0 \\
00 \\
89 \\
81 \\
02 \\
7 \\
\end{tabular} & \begin{tabular}{|r||}
0.0 \\
00 \\
65 \\
01 \\
31 \\
9 \\
\end{tabular} & \begin{tabular}{|r||} 
\\
\\
0.00 \\
0375 \\
3859 \\
\end{tabular} & \begin{tabular}{||r||}
0.0 \\
00 \\
17 \\
72 \\
88 \\
3 \\
\end{tabular} & 0 & 0 & $\begin{array}{l}5342 \\
284 \mathrm{E} \\
-005\end{array}$ \\
\hline & |4.1 & $|4.1|$ & & $\mid$ & $\mid$\begin{tabular}{||c|}
$\mid$ \\
$\mid$
\end{tabular} & $|4.1|$ & | 4.1 & $|4.1|$ & & & $\mid 4.12$ & & 4.12 & & & $\mid 4.0$ & & $|4.1|$ & & || $4.1 \|$ & |4.1 & 4.1 & 4.10 \\
\hline
\end{tabular}




\begin{tabular}{|r|r|r|r||r||r|r||r||r|r|r||r|r|r|r|r||r|r|r|r||r||r|r|r|}
\hline $\mathrm{u}$ & 32 & 05 & 01 & 17 & 08 & 09 & 23 & 27 & 03 & 09 & 8690 & 18 & 1175 & 05 & 77 & 99 & 98 & 07 & 5256 & 38 & 16 & 00 & 7414 \\
$\mathrm{~m}$ & 35 & 45 & 53 & 23 & 53 & 16 & 34 & 93 & 59 & 39 & 8922 & 47 & 0745 & 04 & 55 & 29 & 03 & 41 & 5584 & 26 & 64 & 15 & 9724 \\
& 28 & 98 & 56 & 71 & 53 & 83 & 65 & 77 & 81 & 14 & & 21 & & 96 & 09 & 72 & 57 & 03 & & 84 & 37 & 77 & \\
& 31 & 15 & 62 & 53 & 26 & 00 & 01 & 97 & 30 & 07 & & 43 & & 82 & 13 & 99 & 58 & 04 & & 29 & 19 & 50 & \\
& 8 & 1 & 6 & 9 & 9 & 3 & 7 & 3 & 7 & 3 & & 3 & & 9 & 4 & 2 & 5 & 6 & & 4 & 2 & 1 & \\
\hline
\end{tabular}
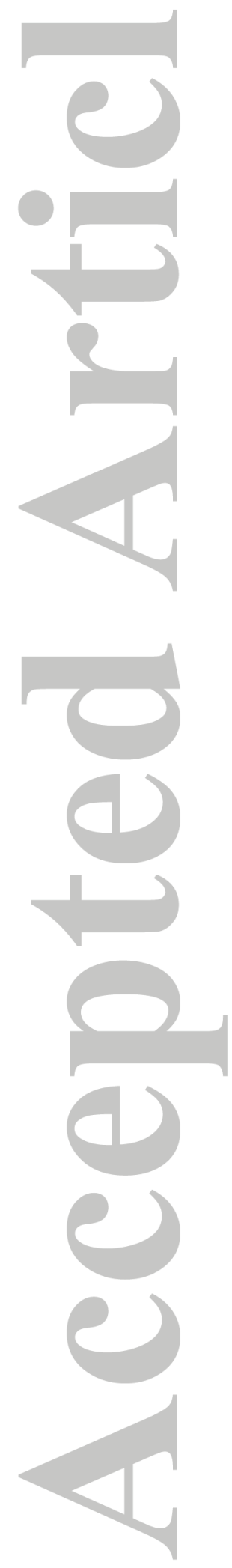
Table 3: Microprobe data of clinozoisite and omphacite in eclogite sample SY4. See Fig. 3D for location of measurements.

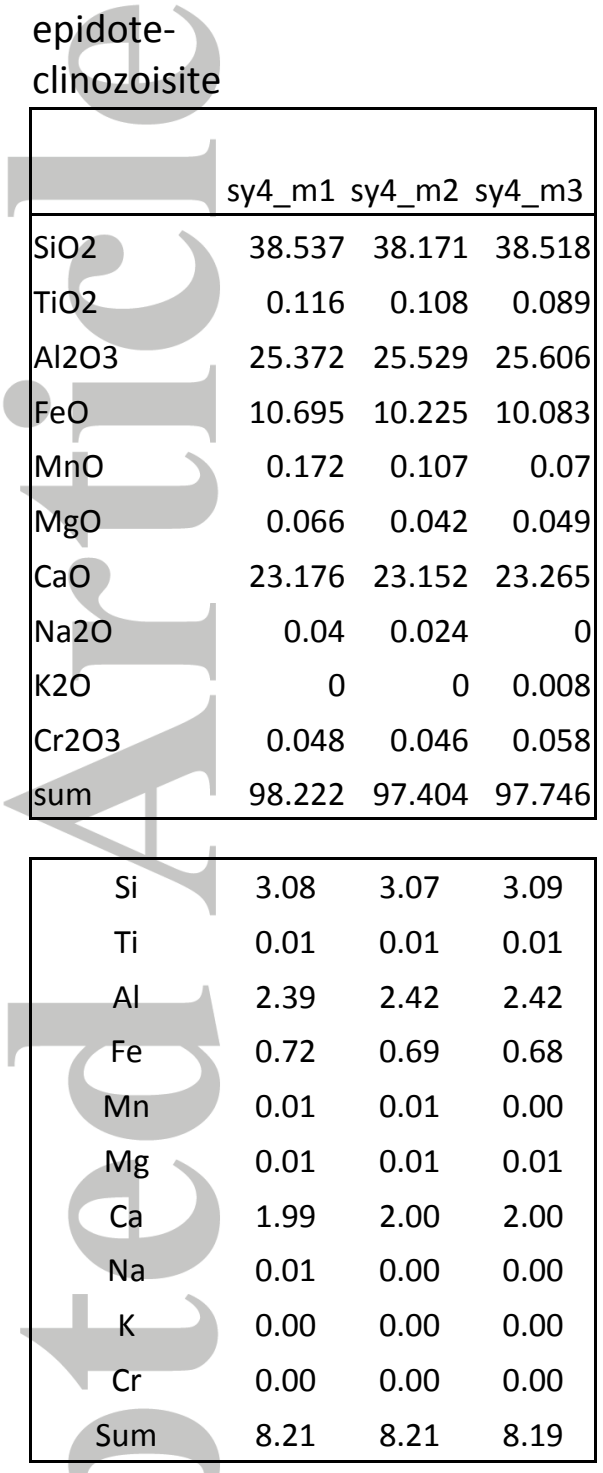

omphacite

\begin{tabular}{|rrrrrrrr|}
\hline \multicolumn{1}{|c|}{ sy4_m4 } & sy4_m5 & sy4_m6 & sy4_m7 & sy4_m8 & sy4_m9 & sy4_m10 \\
\hline 55.937 & 55.711 & 55.136 & 55.123 & 55.761 & 55.102 & 57.561 \\
0.048 & 0.066 & 0.019 & 0.056 & 0.045 & 0.055 & 0.053 \\
11.561 & 10.26 & 9.066 & 10.244 & 11.069 & 10.942 & 9.64 \\
9.513 & 11.29 & 12.273 & 10.74 & 9.554 & 10.259 & 13.106 \\
0.011 & 0.091 & 0.155 & 0.166 & 0.021 & 0.059 & 0.112 \\
4.821 & 4.642 & 4.927 & 4.98 & 5.159 & 5.159 & 9.377 \\
7.892 & 8.314 & 8.648 & 9.513 & 8.743 & 9.167 & 0.256 \\
9.724 & 9.568 & 9.188 & 8.652 & 9.4 & 9.184 & 7.663 \\
0.019 & 0.013 & 0 & 0 & 0 & 0 & 0.002 \\
0.039 & 0.057 & 0.023 & 0.052 & 0.011 & 0.056 & 0.006 \\
99.565 & 100.012 & 99.435 & 99.526 & 99.763 & 99.983 & 97.776 \\
\hline \multicolumn{7}{c}{}
\end{tabular}

\begin{tabular}{|lllllll|}
\hline 2.03 & 2.03 & 2.04 & 2.02 & 2.02 & 2.01 & 2.09 \\
0.00 & 0.00 & 0.00 & 0.00 & 0.00 & 0.00 & 0.00 \\
0.49 & 0.44 & 0.40 & 0.44 & 0.47 & 0.47 & 0.41 \\
0.29 & 0.34 & 0.38 & 0.33 & 0.29 & 0.31 & 0.40 \\
0.00 & 0.00 & 0.00 & 0.01 & 0.00 & 0.00 & 0.00 \\
0.26 & 0.25 & 0.27 & 0.27 & 0.28 & 0.28 & 0.51 \\
0.31 & 0.33 & 0.34 & 0.37 & 0.34 & 0.36 & 0.01 \\
0.68 & 0.68 & 0.66 & 0.62 & 0.66 & 0.65 & 0.54 \\
0.00 & 0.00 & 0.00 & 0.00 & 0.00 & 0.00 & 0.00 \\
0.00 & 0.00 & 0.00 & 0.00 & 0.00 & 0.00 & 0.00 \\
4.06 & 4.08 & 4.09 & 4.06 & 4.07 & 4.08 & 3.97 \\
\hline
\end{tabular}

(C) 2017 American Geophysical Union. All rights reserved. 
Table 4: P- and S-wave velocities and anisotropies of samples SY1, SY2, SY4 and SY5. Iso is the VRH isotropic average.

\begin{tabular}{|c|c|c|c|c|c|c|c|c|c|c|c|}
\hline Sample & Lithology & \begin{tabular}{|l} 
Vpiso \\
$(\mathrm{km} / \mathrm{s})$
\end{tabular} & $\begin{array}{l}\min \\
(\mathrm{km} / \mathrm{s})\end{array}$ & $\begin{array}{l}\max \\
(\mathrm{km} / \mathrm{s})\end{array}$ & Ap (\%) & $\begin{array}{l}\text { Vsiso } \\
(\mathrm{km} / \mathrm{s})\end{array}$ & $\begin{array}{l}\text { Vs1 min } \\
(\mathrm{km} / \mathrm{s})\end{array}$ & $\begin{array}{l}\text { Vs1 max } \\
(\mathrm{km} / \mathrm{s})\end{array}$ & $\begin{array}{l}\text { Vs2 min } \\
(\mathrm{km} / \mathrm{s})\end{array}$ & $\begin{array}{l}\text { Vs2 max } \\
(\mathrm{km} / \mathrm{s})\end{array}$ & $V p / V s$ \\
\hline sy & Blueschist & 7.82 & 7.15 & 8.09 & 12.1 & 4.45 & $4.4 C$ & 4.73 & 4.40 & 4.51 & 1.76 \\
\hline Sy2 & Eclogite & 7.89 & 7.76 & 8.06 & 3.7 & 4.64 & 4.62 & 4.70 & 4.60 & 4.64 & 1.70 \\
\hline & Eclogite & 7.76 & 7.64 & 7.90 & 3.3 & 4.58 & 4.55 & 4.64 & 4.54 & 4.59 & 1.69 \\
\hline Sy5 & Blueschist & 7.43 & 7.24 & 7.72 & 6.5 & 4.35 & 4.34 & 4.43 & 4.28 & 4.37 & 1.71 \\
\hline
\end{tabular}
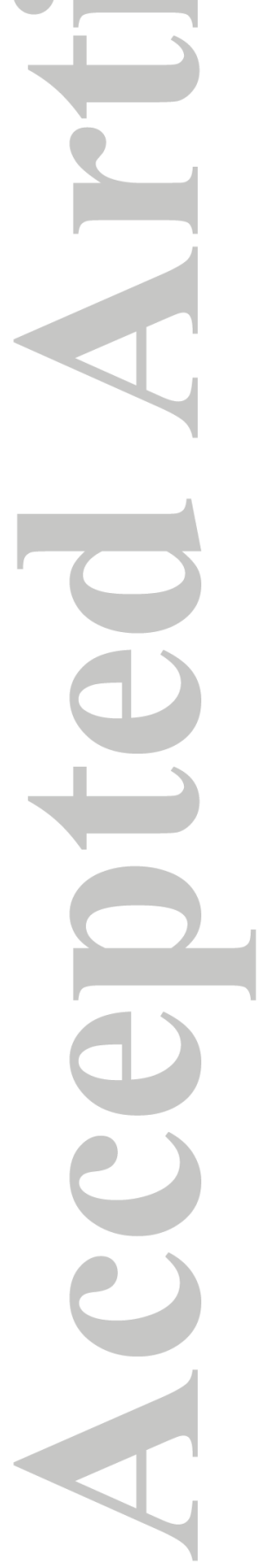
Table 5: Tensor components of elastic moduli for the four samples studied.

\begin{tabular}{|c|c|c|c|c|}
\hline & SY1 & SY2 & SY4 & SY5 \\
\hline C11C11 & 65.1 & 64.7 & 61.2 & 59.5 \\
\hline C12C12 & 17.1 & 20.0 & 17.7 & 17.2 \\
\hline C13C13 & 20.5 & 19.5 & 18.7 & 17.9 \\
\hline C14C14 & 0.5 & 0.1 & 0.1 & -0.2 \\
\hline C15C15 & -0.1 & -0.2 & 0.6 & -0.4 \\
\hline C16C16 & 0.1 & 0.3 & 0.4 & 0.1 \\
\hline C22C22 & 51.3 & 63.3 & 58.5 & 52.6 \\
\hline C23C23 & 17.0 & 19.4 & 17.8 & 17.0 \\
\hline$C 24 C 24$ & 0.7 & 0.3 & -0.1 & -0.4 \\
\hline C25C25 & 0.0 & -0.1 & -0.2 & 0.0 \\
\hline C26C26 & 0.0 & 0.2 & 0.1 & 0.1 \\
\hline C33C33 & 64.9 & 60.4 & 60.8 & 54.6 \\
\hline C34C34 & 1.3 & 0.3 & -0.1 & -0.4 \\
\hline C35C35 & -0.1 & -0.2 & 0.5 & -0.2 \\
\hline C36C36 & 0.0 & 0.0 & 0.1 & 0.0 \\
\hline$C 44$ & 19.5 & 21.2 & 20.7 & 18.4 \\
\hline$C 45$ & 0.0 & 0.1 & 0.1 & 0.0 \\
\hline$C 46$ & 0.0 & -0.1 & 0.0 & -0.1 \\
\hline C55 & 22.3 & 21.4 & 21.5 & 19.3 \\
\hline C56 & 0.4 & 0.1 & 0.1 & -0.2 \\
\hline C66 & 19.4 & 22.0 & 20.7 & 18.9 \\
\hline
\end{tabular}




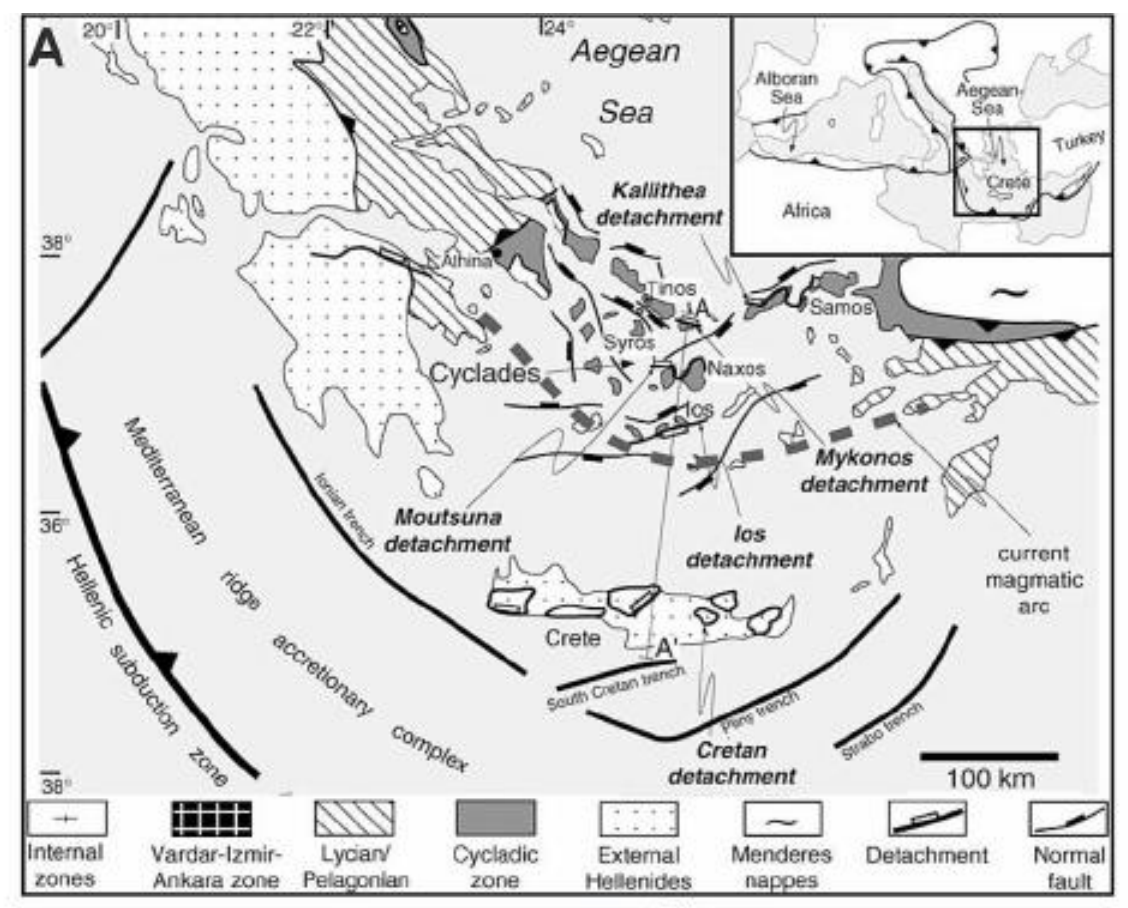

Cycladic Blueschist Unit
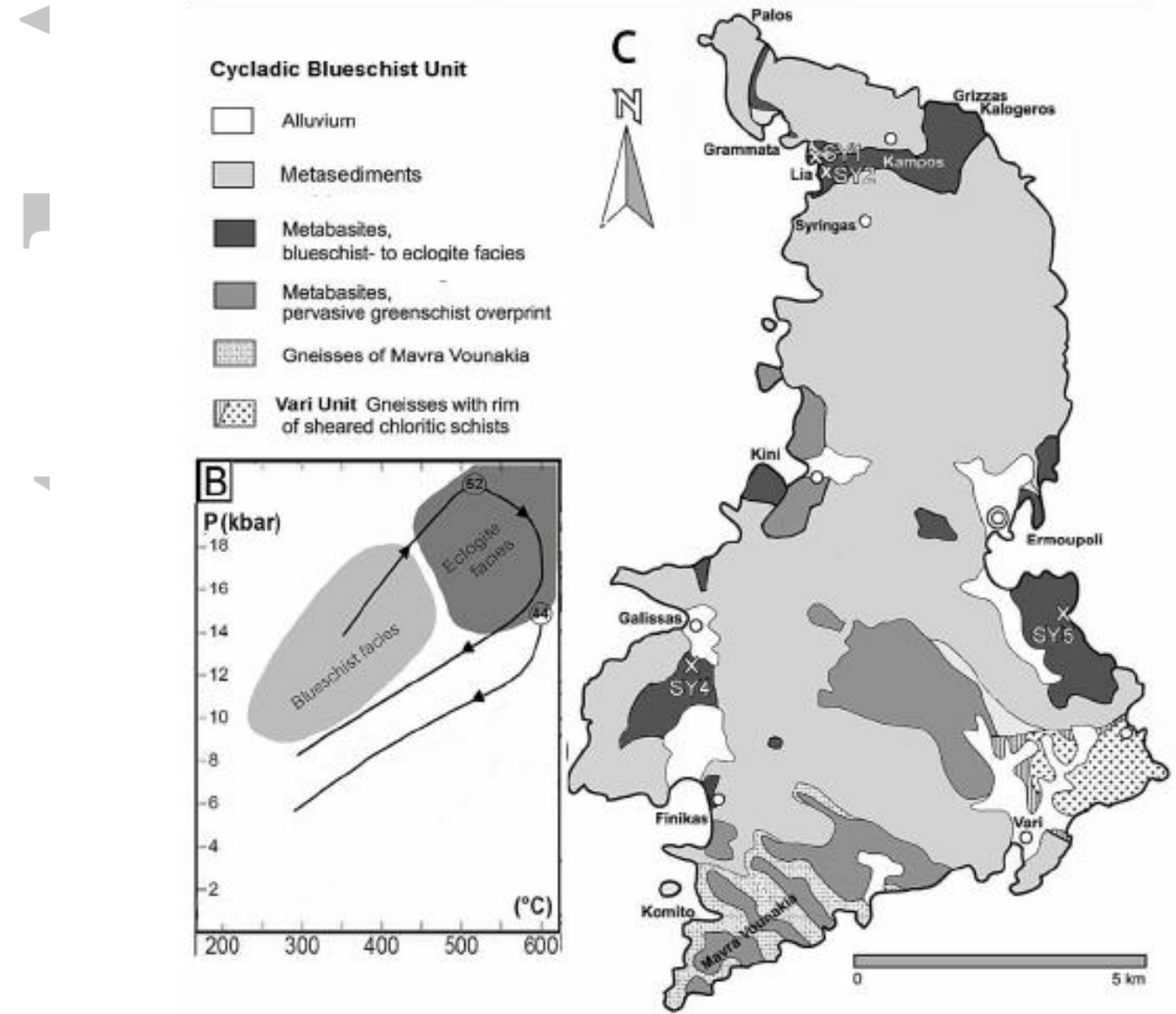

ault

Fig. 1: A: Overview map of the Cyclades (after Ring et al., 2003); B: Pressure-Temperature path of Syros (upper path) and Sifnos (lower path) from Jolivet and Brun (2010) based on the data from Trotet et al. (2001a; b), numbers indicate time of peak pressure metamorphism in Ma; C: Map of the major lithological units of Syros (from Keiter et al., 2004). 

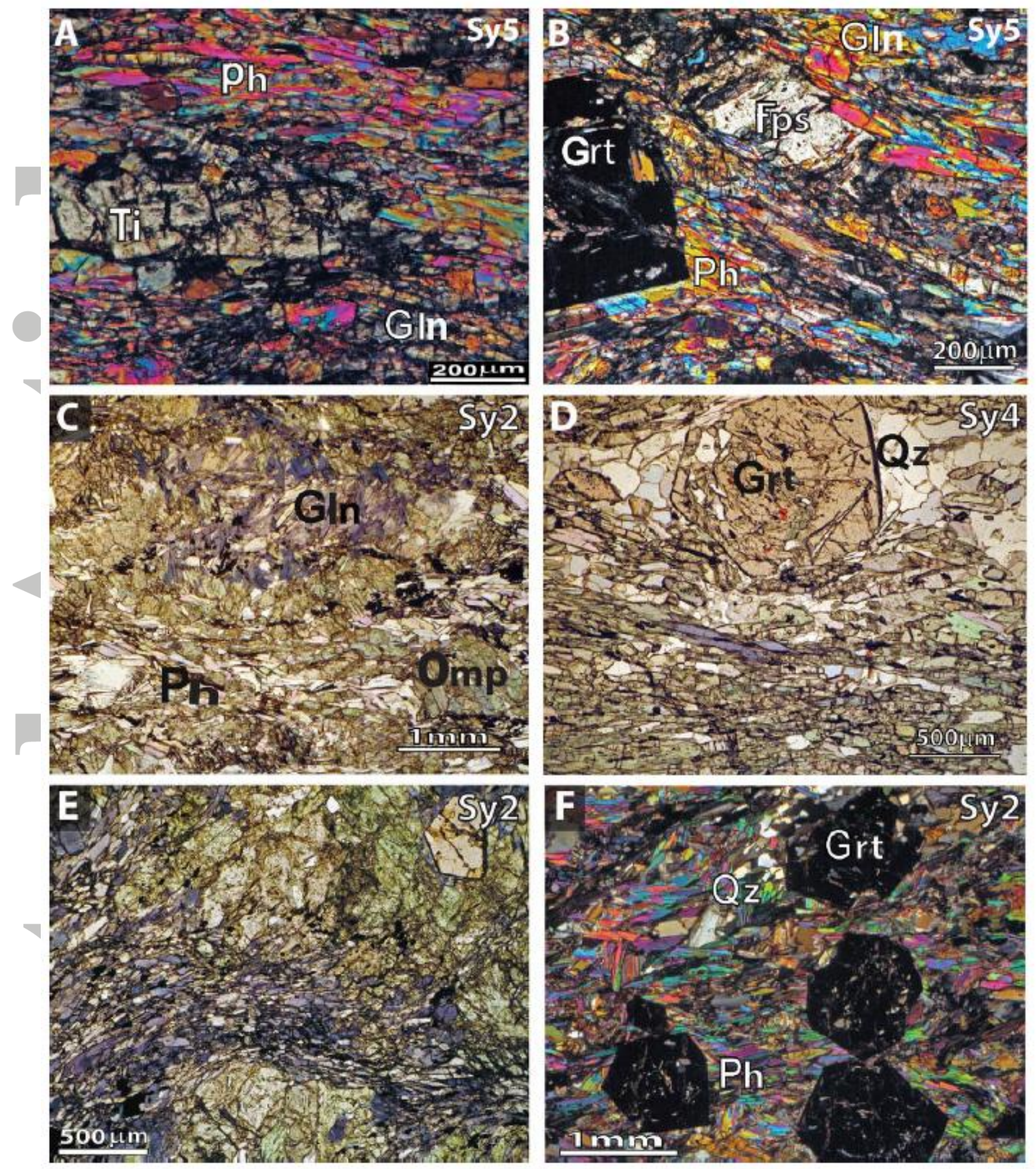

Fig. 2: Light-optical micrographs of the investigated blueschist $(A, B)$ and eclogite (C-F) samples. (A) Well aligned Ph: phengite, Ti: titanite and Gln: glaucophane in the foliation of a blueschist; (B) phengite and glaucophane in pressure shadows of feldspar and garnet; (C) coarse-grained eclogite with randomly oriented amp: amphibole, phengite and omphacite; (D) quartz in pressure shadows of garnet, surrounded by a matrix of omphacite and glaucophane, well aligned in the foliation; (E) coarse and randomly oriented omphacite grains divided by a zone of small glaucophane grains well aligned in a microshear zone; (F) randomly aligned quartz and phengite in pressure shadows of garnet. Sections are perpendicular to the foliation and parallel to the lineation. A, B, F taken under crossed polarizers, C, D, E under plane-polarized light; Fps: feldspar, Gln: glaucophane, Grt: garnet, Omp: omphacite, Ph: phengite, Qz: quartz, Ti: titanite. All micrographs are taken from sections parallel to the lineation and perpendicular to the foliation. 

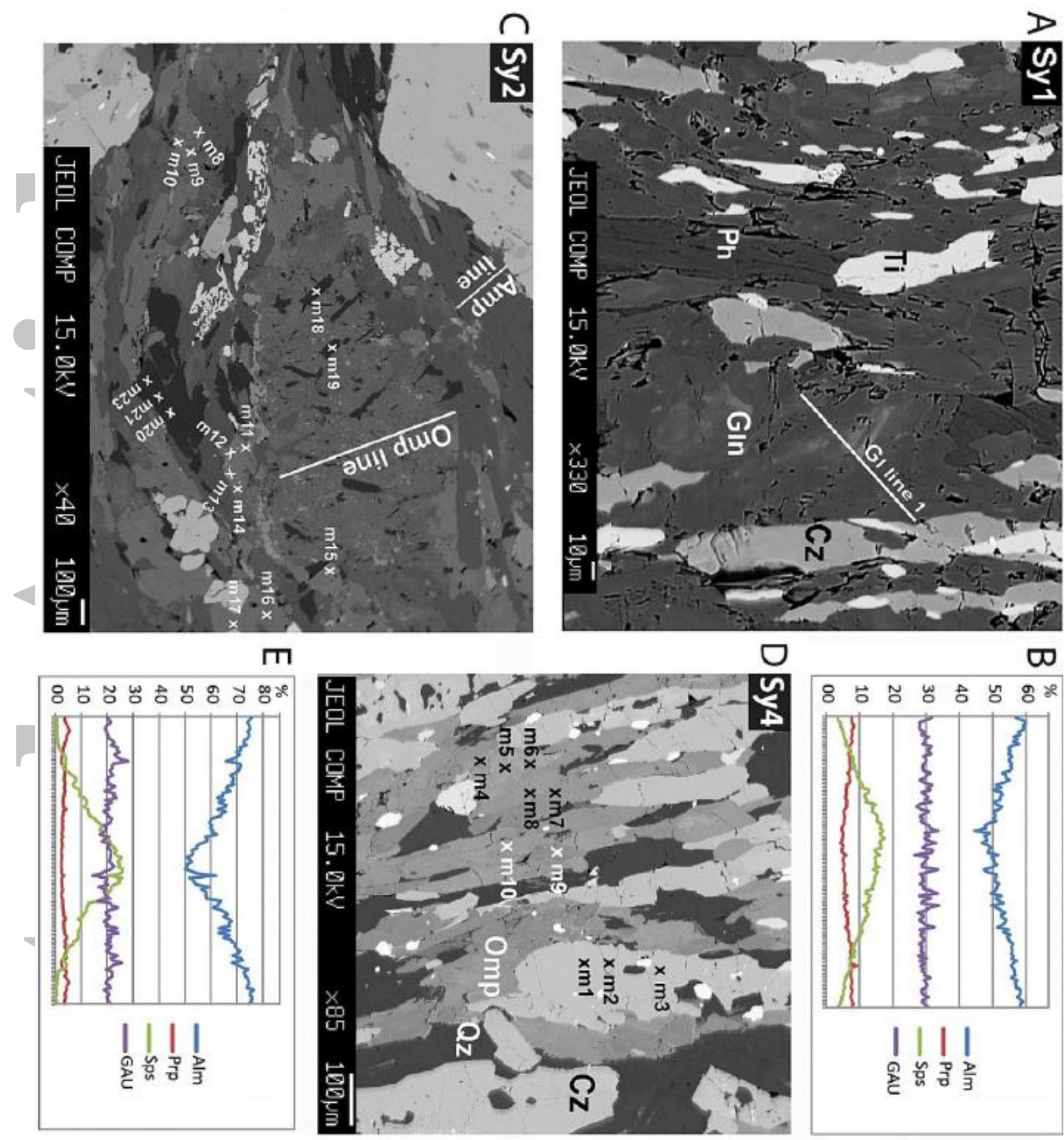

Fig. 3: $A ; C$ and D: Backscatter electron (BSE) images of blueschist $(A)$ and eclogites ( $C$ and $D) ; A m p:$ amphibole, Cz: clinozoisite, Gln: glaucophane, Omp: omphacite, Ph: phengite, Qz: quartz, Ti: titanite. Sample numbers are given in the upper left of each image. (m1-m23): icroprobe measurement points and measurement profiles (Table 2A, B). B and E: Volume $\%$ of garnet components in blueschist sample SY1 (B) and eclogite sample SY2 (E); Alm: almandine, Prp: pyrope, Sps: spessartine, GAU: Grossular+Andradite+Uwanovite. All BSE images are taken from sections parallel to the lineation and perpendicular to the foliation. 


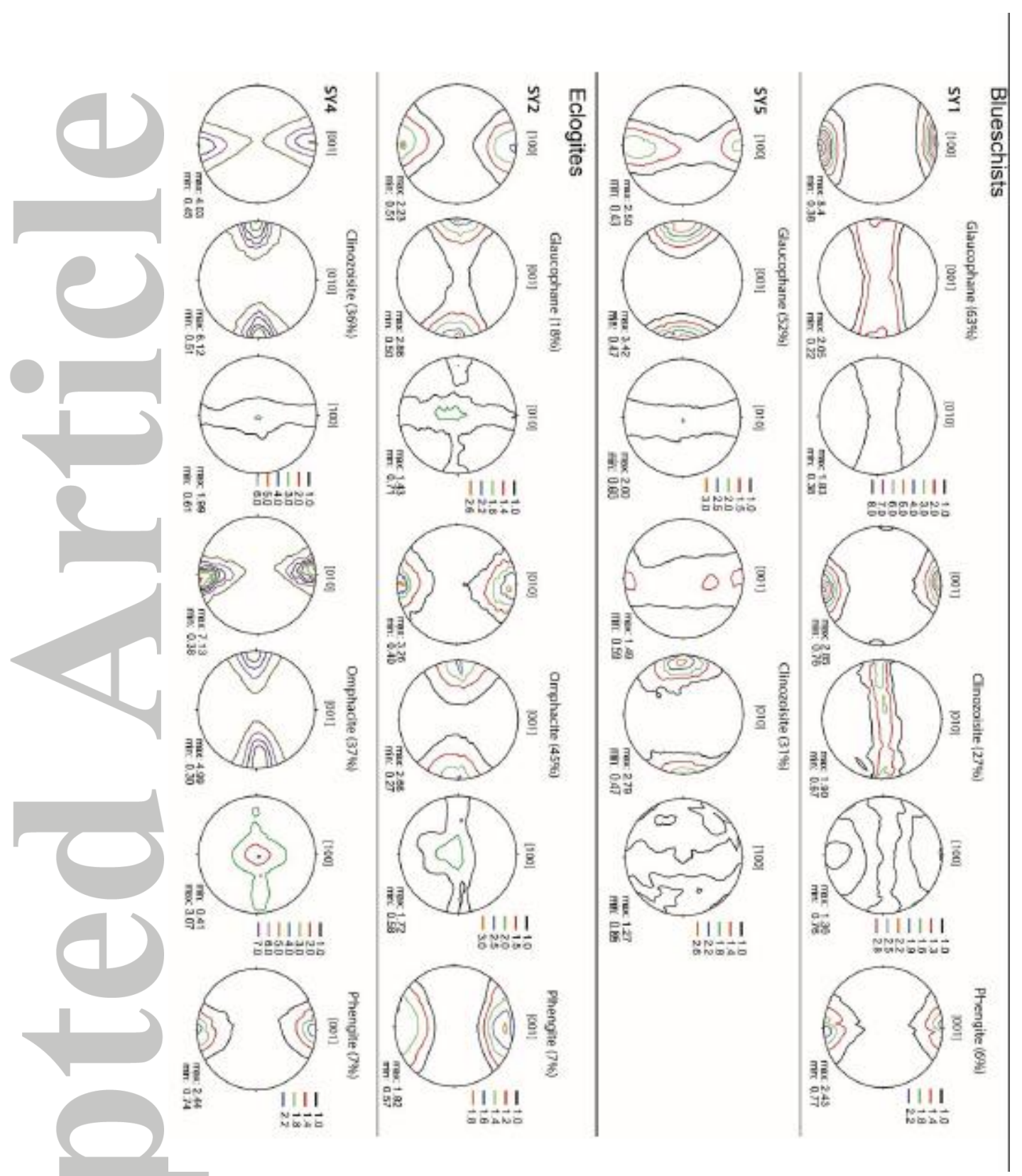

Fig. 4: CPO data of the mineral phases that are important for the elastic anisotropy of the blueschist (SY1, SY5) and eclogite (SY2, SY4) samples. Pole figures are oriented according to foliation and mineral/stretching lineation of glaucophane and omphacite, respectively. The lineation (X-direction of the finite strain ellipsoid) is EW in the pole figure, the foliation normal (Z-direction of the finite strain ellipsoid) is oriented NS, and the Y-direction (perpendicular to X and Z) lies normal to the pole figure plane. Pole figures are lower hemisphere equal area projections on a $5 \times 5^{\circ}$ grid. Contour levels are multiples of a random distribution. Maxima are indicated at the lower right of each pole figure. Only significant pole figures are given. They illustrate the textural differences between samples. See text for pole figure description and discussion.

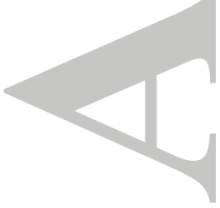



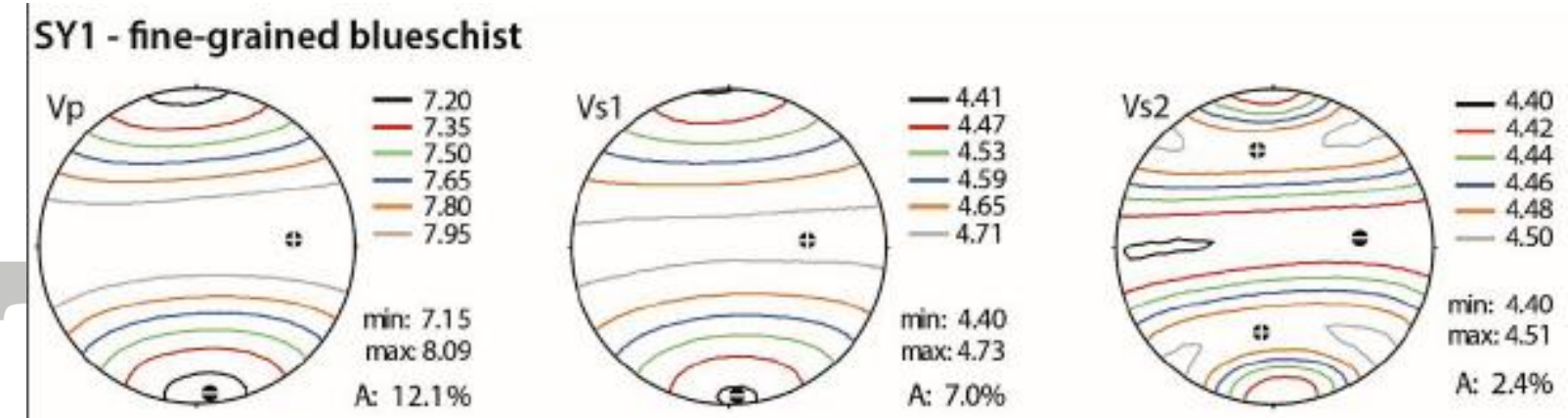

SY2 - glaucophane bearing coarse-grained eclogite
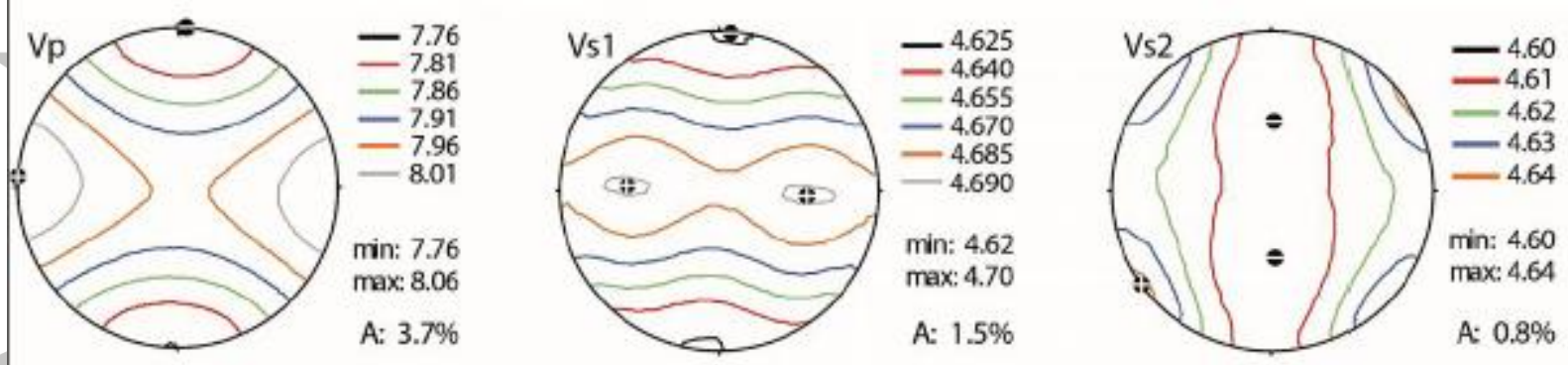

\section{SY4 - fine grained eclogite}
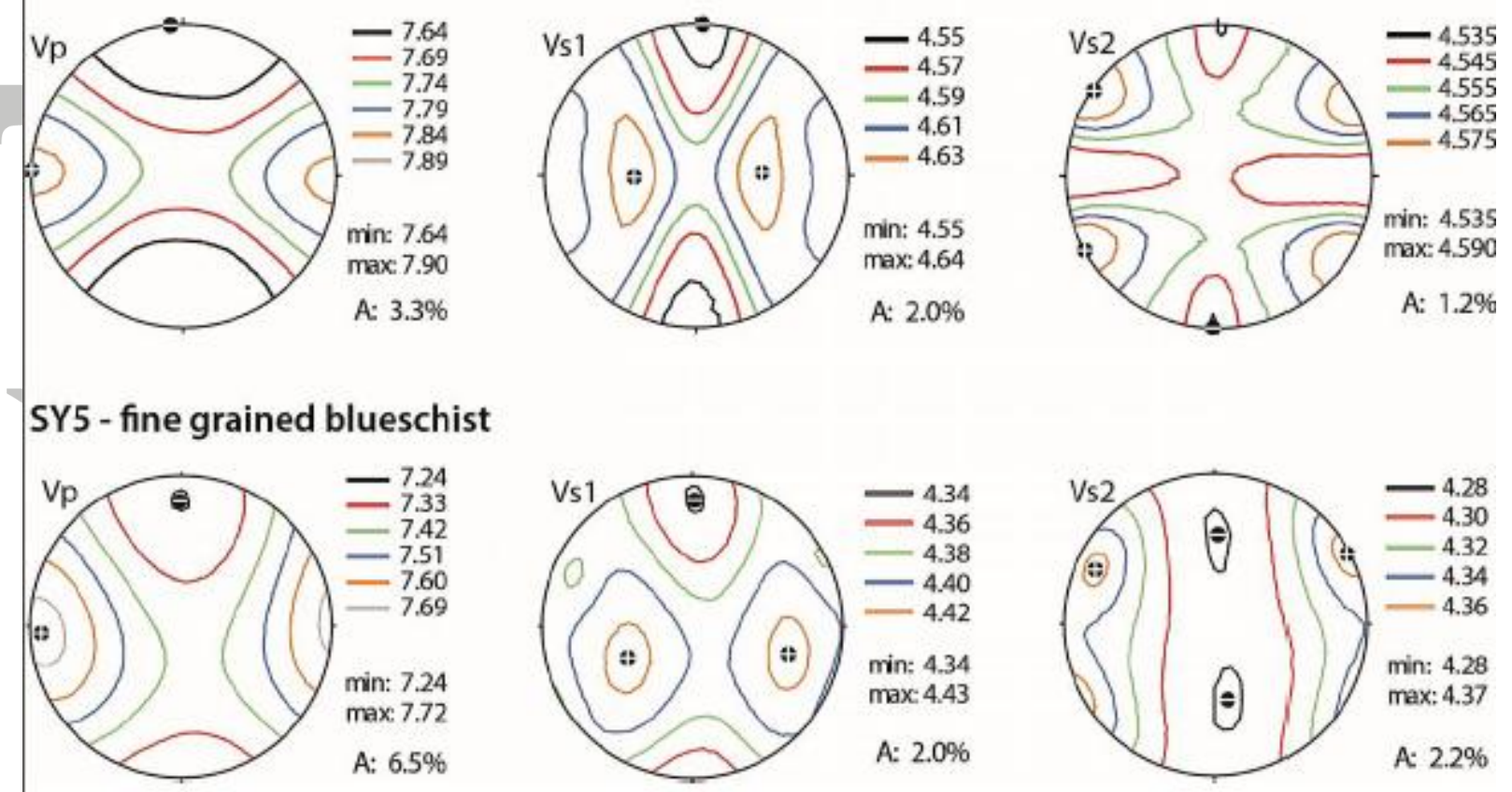

Fig. 5: Modelled P-wave and S-wave velocity distributions of the two blueschist (SY1, SY5) and the two eclogite (SY2, SY4) samples. Colored contour lines show velocities in $\mathrm{km} / \mathrm{s}$. Minimum and maximum velocity is given in the lower right corner of the pole figures, and orientation zones of maximum velocity are surrounded by grey or orange contour lines. A: elastic anisotropy. See text for discussion. 